\title{
The Greek Database of Seismogenic Sources (GreDaSS): state-of-the-art for northern Greece
}

\author{
Riccardo Caputo $^{1,{ }^{\star}}$, Alexandros Chatzipetros ${ }^{2}$, Spyros Pavlides ${ }^{2}$, Sotiris Sboras ${ }^{1,2}$ \\ ${ }^{1}$ Università di Ferrara, Dipartimento di Fisica e Scienze della Terra, Ferrara, Italy \\ ${ }^{2}$ Aristotle University of Thessaloniki, Department of Geology, Thessaloniki, Greece
}

\section{Article history}

Received May 13, 2011; accepted March 30, 2012.

Subject classification:

North Aegean, Seismotectonics, Earthquake geology and palaeoseismology, Active faults, Seismogenic sources.

\section{ABSTRACT}

The Greek Database of Seismogenic Sources (GreDaSS) is a repository of geological, tectonic and active-fault data for the Greek territory and its surroundings. In this report, we present the state-of-the-art of an on-going project devoted to the building of the GreDaSS, which represents the results of decades of investigations by the authors and a myriad of other researchers working on the active tectonics of the broader Aegean Region. The principal aim of this international project is to create a homogeneous framework of all of the data relevant to the seismotectonics, and especially the seismic hazard assessment, of Greece and its surroundings, as well as to provide a common research platform for performing seismic hazard analyses, modeling and scenarios from specific seismogenic structures. In particular, we introduce and synthetically describe the results obtained (and included in the database) to date in the northern sector of continental Greece and the Aegean Sea. As a first step we collected all available (both published and unpublished) historical and instrumental seismicity data relevant to the determining of the causative faults. Following the experience of recent 'surprising' earthquakes (e.g. 1995 Kozani, and 1999 Athens), we realized the deficiency of such an approach, and decided to also include in the GreDaSS active faults (i.e. seismogenic sources) recognized on the basis of geological, structural, morphotectonic, paleoseismological and geophysical investigations. A second step is the critical analysis of all of the collected data for the extraction of the necessary seismotectonic information, enabling the recognition of as many seismogenic sources as possible, as well as their characterization and parameterization. The most updated version of the database consists of numerous seismogenic sources that are categorized into three types: composite, individual, and debated. In this report, we describe the major seismotectonic properties of all of the composite seismogenic sources and individual seismogenic sources in northern Greece, which imply the partitioning of the area into five sectors that show similar internal behavior. Northern Greece was chosen as a pilot area because the parameters and accompanied metadata of its seismogenic sources show a high level of confidence and completeness. The amount of information and the degree of uncertainty is different for the three types.

\section{Introduction}

The broader Aegean Region is among the most tectonically active areas of the Mediterranean realm. The tectonic regime is relatively complex, and produces earthquakes with many different orientations of their P/T axes [Papazachos and Kiratzi 1996, Hatzfeld 1999, Kiratzi and Louvari 2003], and a large variety of fault types, both in terms of dimensions and kinematics. The recent geodynamic evolution of the Aegean Region, and especially its northern sector, which is the focus of this report, is characterised by the dominant crustal stretching and the westward motion of the Anatolian plate along the North Anatolian Fault. This motion is related at the same time to the lithospheric subduction of the retreating African plate beneath the Hellenic Trench [e.g. Caputo et al. 1970] since at least Oligocene period [Le Pichon and Angelier 1979, Gautier et al. 1999]. In more detail, and according to geological, geodetic, seismological and paleomagnetic investigations [Angelier 1979, Mercier 1981, Kissel and Laj 1988, Hatzfeld 1999, Papazachos 1999, Kondopoulou 2000, Papazachos 2002], the tectonics of the Aegean Region is much more complex than that, as the inner part undergoes intense internal deformation. Indeed, the area is characterized by intense seismicity both in terms of magnitude and frequency.

Earthquakes have caused many casualties in both human lives and destruction in Greece since the early known historical events [e.g. Papazachos and Papazachou 1997, Papadopoulos 2000]. The seismic risk nowadays is even greater than in the past, due to the denser population, living in large urban areas that are characterized by a higher building complexity. A representative example is the September 7, 1999 $\left(M_{s}=5.9\right)$ Athens earthquake, which even though it was a moderate-sized earthquake, it strongly affected the metropolitan area of Athens, which includes nearly half of the Greek population, causing many deaths and severe damage. Previously, the area was considered to be of low seismic ac- 
tivity, as no important earthquakes had been reported either historically or instrumentally [Papadimitriou et al. 2002], and the causative Fili Fault [Pavlides et al. 2002], which has clear morphotectonic expression [Ganas et al. 2004], was not recognized as an active fault until then.

Although shallow, earthquakes in Greece commonly occur along well-defined zones (e.g. Gulf of Corinth, South Thessaly, Ionian Sea); moderate to large earthquakes ( $M \geq 5.5)$ have also occurred in regions where seismicity was very low or totally absent and were considered as aseismic blocks (e.g. Kozani and Athens, as the two most recent examples). As a consequence, seismic hazard assessment should not be estimated only based on historically or instrumentally wellknown sources [Pavlides and Caputo 2004, Caputo et al. 2008], as it needs complementary, more geological, investigational approaches. Indeed, the recognition of active faults and their seismotectonic characterization with other nonseismological tools represent crucial contributions to the seismic hazard assessment of a highly seismogenic region like Greece and its surroundings. In this regard, active faults are often studied individually or at a regional scale. This causes two effects: first, the data are scattered and sometimes 'hidden' in various studies; and secondly, the data are sometimes inconsistent when they derive from investigations carried out by different approaches and different authors.

Having foreseen the importance to hold and manage all of the data collected from active fault investigations, many research institutes worldwide have built databases at the national scale. For example, GNS Science in New Zealand (http:// data.gns.cri.nz/af/), the Institute of Advanced In- dustrial Science and Technology in Japan (http: / / riodb02. ibase.aist.go.jp/activefault/index_e.html), the United States Geological Survey (http:/ / pubs.usgs.gov/fs/2004/3033/fs2004-3033.html) and the Istituto Nazionale di Geofisica e Vulcanologia in Italy (INGV; http:/ / diss.rm.ingv.it/diss/) have the most developed databases of active faults. Following the track, but especially feeling the need to fill a scientific gap, our working-group is currently building a similar database for the Aegean Region, the Greek Database of Seismogenic Sources (GreDaSS). It is a continuously updatable database of all of the faults re-actived in historical or instrumental times, as well as of geologically determined active faults (Figure 1). The database provides many levels of consistent and uniform information, like the principal seismotectonic parametres (e.g. location, geometry, kinematics), descriptions (e.g. comments, open questions, and literature summaries, Figures, relevant literature), and much more.

The GreDaSS is already part of the Seismic Hazard Harmonization in Europe (SHARE) project, a European-scale project that involves all of the steps leading to a harmonized assessment of seismic hazard - in definition of engineering requirements, in collection and analysis of input data, in procedures for hazard assessment, and in engineering applications. Although the state-of-the-art of the Greek database covers the entire Aegean Region in the framework of the SHARE project, northern Greece is presented in this report as a pilot area, because it documents the highest level of completeness for both seismogenic sources and their associated metadata. As part of the SHARE project, the efforts of our working group have also contributed to the world-wide

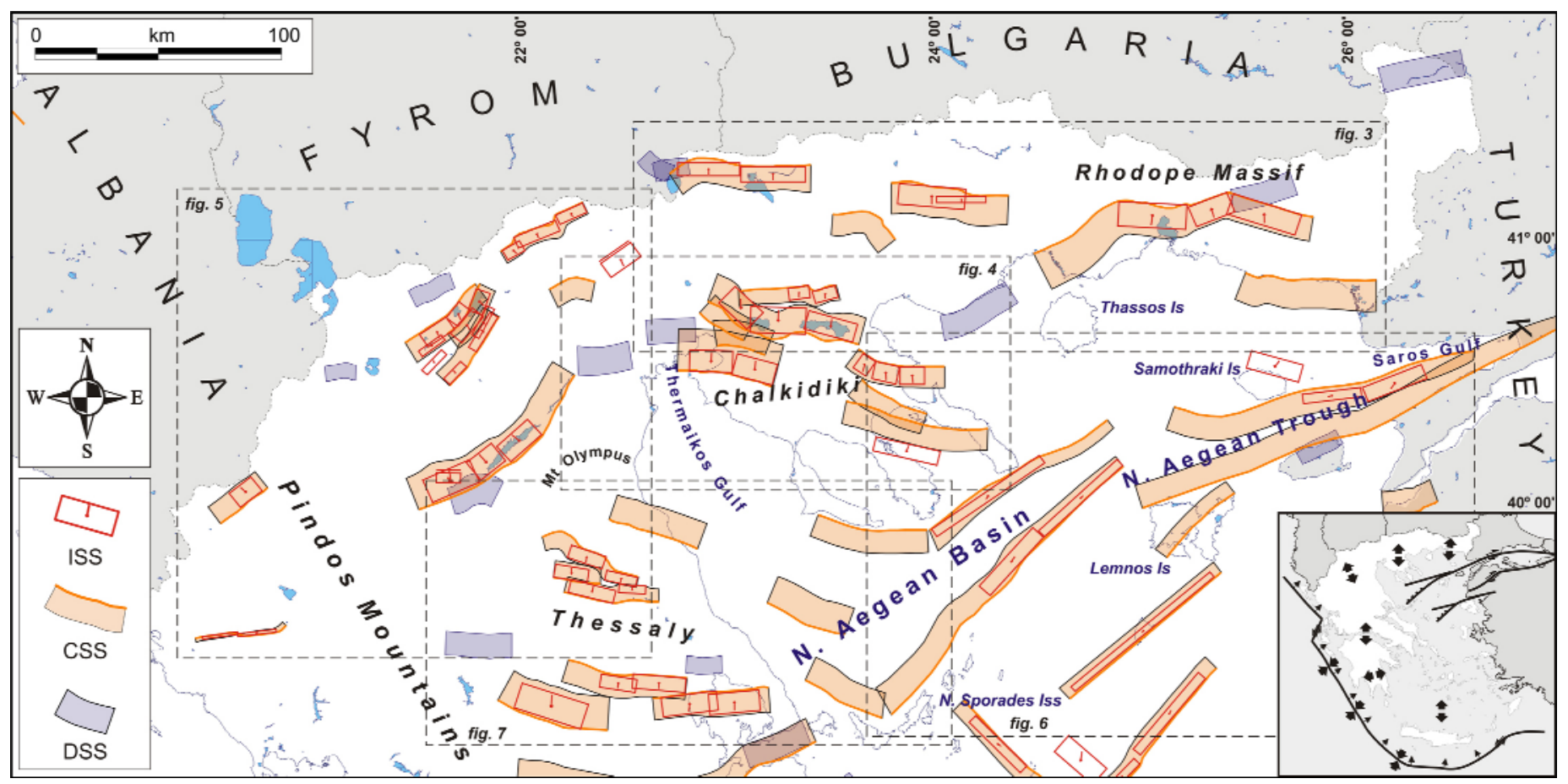

Figure 1. Map of the seismogenic sources recognized in the Northern Aegean region and included to date in the GreDaSS. Inset: Overview of the region. Dashed boxes indicate Figures for further details. ISS, individual seismogenic sources; CSS, composite seismogenic sources; DSS, debated seismogenic sources. 
Global Earthquake Model (GEM) project.

The informatic structure and methodological approaches of the GreDaSS are based on the well-tested, timeproven, worldwide acknowledged database proposed by the INGV for the Italian Database of Individual Seismogenic Sources (DISS), which represents the result of almost 20 years research experience of its Working Group [Valensise and Pantosti 2001, Basili et al. 2008]. It is built in a geographic information system (GIS) environment, which contains all of the necessary geographical information for the appropriate representation, and all of the available structural parameters, which are accompanied by comments, open questions, short summaries of the available literature, and selected figures. The seismogenic sources consist of three main types: Composite Seismogenic Sources (CSSs), Individual Seismogenic Sources (ISSs), and Debated Seismogenic Sources (DSSs).

It is important to include a few words on the terms 'seismogenic source', 'capable fault' and 'active fault'. Indeed, their distinction is subtle, because a tectonic structure that has been ruptured in the recent past (historical-instrumental period) is generally considered a 'seismogenic source', although it will probably remain 'inactive' for several centuries, or even for thousands of years (i.e. interseismic period). Accordingly, such a structure might be of no interest for seismic hazard assessment (SHA) analyses. On the other hand, for SHA purposes, we are certainly more interested in the 'capable fauts' (i.e. faults that in the present stress regime might generate moderate-to-strong events, say with $M>5.5$ ) as they will eventually become seismogenic sources in the more or less near future. For the aims of this study, the two terms have a large overlap in meaning, given that a seismogenic source was a capable fault, and a capable fault sooner or later will become a seismogenic source. In a geological perspective (i.e. over much longer than a single seismic cycle), the expression 'active fault' generally embraces both terms. For the sake of simplicity, here we use the two terms with the above-defined meanings, but we also refer to both types of structures as active faults.

The present study is not focused on a description of the philosophy, structure and technical issues of the database; this information can be found in Basili et al. [2008]. The principal aim of the present study is to present the state-of-the-art of the GreDaSS by synthesizing all of the seismogenic sources included in northern Greece, as far as this region is satisfactorily complete. The investigations for other sectors of the Aegean are still in progress, and they will be not presented and discussed here.

It is important to remember that four parameters (length, width, slip-per-event and magnitude) of ISSs are interconnected by seismological scaling relationships [Kanamori and Anderson 1975, Hanks and Kanamori 1979, Wells and Coppersmith 1994], as was described at length by Basili et al. [2008]. Therefore, if a parameter is lacking, it is common practice to obtain it accordingly, using empirical relationships. A typical example is represented by the information relative to the average displacement (or the slip-per-event), which is often missing and which can be estimated using the empirical relationship of rupture area (length $\times$ width) versus magnitude [Wells and Coppersmith 1994] and inverting the seismic moment equation, keeping constant rigidity $\left(3.5 \times 10^{10} \mathrm{~Pa}\right)$ and resolving for slip.

With the exception of the choice relative to the length parameter, which is based on possible structural complexities and the occurrence of possible segment boundaries, the methodological approach for the CSSs is the same as for the ISSs.

For the maximum expected magnitude for both ISSs and CSSs, the values reported in the corresponding Tables were obtained by using the empirical relationship of magnitude versus rupture area [Wells and Coppersmith 1994].

All isolated faults of limited dimensions, and particularly those not capable of producing at least moderate earthquakes $(M \geq 5.5)$, are deliberately excluded from the database. On the other hand, ISSs can consist of smaller geological segments which can be briefly described through the ISS properties. A CSS can also consist of many ISSs that can be characterized as segments. In this case, an ISS is defined as a portion of a greater structure that shows homogeneous seismotectonic behavior in the recent past. This does not exclude the possibility that the segment is presently breached with nearby segments, or that the segments behave always as a unique rupture surface, or will behave as a unique seismogenic source in the future. For this reason, the likelihood that a single event will occur to reactivate either breached, linked or as-yet isolated segments is also discussed for each CSS.

\section{Building the database}

For the construction of any database of seismogenic sources, there are two basic steps: first, all of the active faults that affect a specific region need to be recognized; and secondly, each seismogenic structure should be seismotectonically parameterized. To achieve the first step, especially in regions like the Aegean where earthquake catalogs cover a very long time period (ca. $2.5 \mathrm{ka}$ ) and are particularly rich and relatively complete, at least as concerns the large earthquakes, it is common practice to start analyzing the historical and instrumental seismicity that affects the specific region. In particular, large earthquakes are systematically considered and tentatively associated with the specific causative fault (Figure 2; Table 1).

Like many other places around the world, the seismicity in northern Greece is not homogeneously distributed, either in frequency or in density. Historical information is similarly not uniform all over the region, and even the most complete and updated earthquake catalogs [Ambraseys and Jackson 1990, Guidoboni et al. 1994, Papazachos and Papazachou 1997, Ambraseys and Jackson 1998, Ambraseys 2001, Pa- 


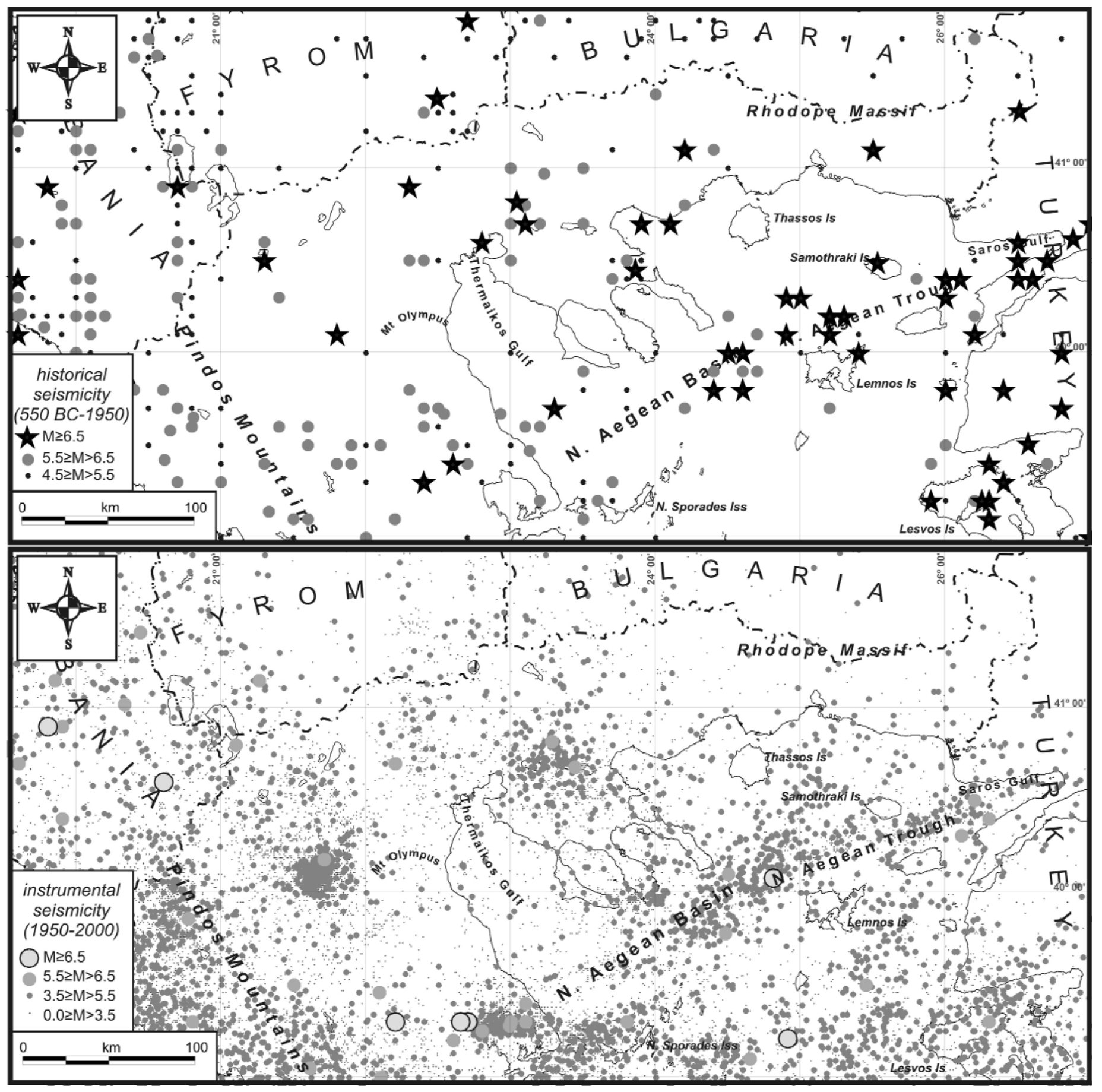

Figure 2. Historical seismicity (top; from Papazachos and Papazacou 1997) and instrumental seismicity (bottom; from the National Observatory of Athens, Greece) in the Northern Aegean region.

pazachos and Papazachou 2003, Guidoboni and Comastri 2005, Ambraseys 2009] are in some cases contradictory or doubtful in the descriptions of past events, and especially the older ones. Accordingly, this hampers quantitative exploitation of the data, and sometimes makes the correlation of the events with any recognized fault difficult [Caputo et al. 2008]. For example, a quick view of the entire study area (Figure 2) shows sparse and infrequent seismicity in Eastern Macedonia and the Thrace Region, where no significant seismicity has been recorded instrumentally. On the contrary, central Macedonia and Chalkidiki show intense activity, which includes instrumentally recorded events (e.g. the 1932 Ierissos earth- quake, and the 1978 Thessaloniki earthquake) and many historic events. West Macedonia had demonstrated extremely low seismicity [Voidomatis 1989, Papazachos 1990] until May 15,1995 , when a $\mathrm{M}_{\mathrm{w}}=6.5$ earthquake occurred in the vicinity of Kozani. The pattern then changed back to sparse and infrequent seismicity, with a few instrumentally recorded moderate events in the area of Epirus, and generally in the broader northwestern Greece. A possible explanation for this difference is that the historical record is obviously richer in densely populated areas, while mountainous regions like Epirus have always been sparsely populated, and hence the historical record might be missing. Nevertheless, the instru- 


\begin{tabular}{|c|c|c|c|c|c|}
\hline $\begin{array}{l}\text { Date } \\
(\text { yyyy/mm/dd })\end{array}$ & $\begin{array}{l}\text { Latitude } \\
\left({ }^{\circ} \mathbf{N}\right)\end{array}$ & $\begin{array}{l}\text { Longitude } \\
\left({ }^{\circ} \mathrm{E}\right)\end{array}$ & $\mathbf{M}$ & ISS & CSS \\
\hline \multicolumn{6}{|c|}{ Northern Greece fault belt } \\
\hline $1784 / 11 / 06$ & 41.1 & 25.5 & 6.7 & Komotini & \\
\hline $1829 / 04 / 11$ & 41.1 & 24.2 & $\mathrm{n} / \mathrm{a}$ & Xanthi & \\
\hline $1829 / 05 / 05$ & 41.1 & 24.2 & 7.3 & Drama and Prosotsani & Drama \\
\hline \multicolumn{6}{|c|}{ Chalkidiki fault system } \\
\hline 677 & 40.70 & 23.50 & 6.4 & & \\
\hline 700 & 40.70 & 23.10 & 6.5 & & \\
\hline $1420 / 07$ & 40.80 & 23.10 & 6.0 & & \\
\hline $1430 / 03 / 26$ & 40.70 & 23.20 & 6.0 & & \\
\hline 1677 & 40.50 & 23.00 & 6.2 & Souroti & \\
\hline $1759 / 06 / 22$ & 40.60 & 22.80 & 6.5 & Angelochori & \\
\hline $1902 / 07 / 05$ & 40.82 & 23.04 & 6.5 & Langadhas & \\
\hline $1932 / 09 / 26$ & 40.45 & 23.86 & $6.9-7.0$ & & Stratoni-Varvara \\
\hline $1932 / 05 / 11$ & 40.4 & 23.7 & 6.3 & & Gomati \\
\hline $1978 / 06 / 20$ & 40.61 & 23.27 & 6.5 & Gerakarou & \\
\hline \multicolumn{6}{|c|}{ 'Anti-Hellenides' fault system } \\
\hline $1395 / 10$ & 40.9 & 22.3 & 6.7 & & \\
\hline $1695 / 09 / 26$ & 40.1 & 21.8 & 6.5 & Rymnio? & \\
\hline $1990 / 12 / 21$ & 40.92 & 22.36 & 6.0 & Goumenissa & \\
\hline $1995 / 05 / 13$ & 40.16 & 21.67 & 6.6 & Palaeochori and Rymnio & \\
\hline $1996 / 07 / 26$ & 40.08 & 20.61 & 5.3 & Konitsa & \\
\hline \multicolumn{6}{|c|}{ North Aegean Sea fault system } \\
\hline 197 B.C. & 40.0 & 25.4 & 7.0 & & Lemnos \\
\hline $1719 / 07 / 23$ & 40.4 & 26.0 & 6.7 & Samothraki SE & \\
\hline $186 / 008 / 06$ & 40.4 & 25.8 & 6.2 & Samothraki SE & \\
\hline $1893 / 02 / 09$ & 40.49 & 25.53 & 6.8 & North Samothraki & \\
\hline $1905 / 11 / 08$ & 40.0 & 24.5 & 7.5 & Athos & \\
\hline 1912/08/09 & 40.62 & 26.88 & 7.6 & & \\
\hline $1968 / 02 / 19$ & 39.5 & 25.0 & 7.1 & Aghios Efstratios & \\
\hline $1975 / 03 / 27$ & 40.4 & 26.1 & 6.6 & Saros & \\
\hline $1982 / 01 / 18$ & 39.78 & 24.5 & 7.0 & NAB Segment B & \\
\hline $1983 / 08 / 06$ & 40.0 & 24.7 & 6.8 & NAB Segment A & \\
\hline $2003 / 07 / 06$ & 40.38 & 26.25 & 5.7 & Saros & \\
\hline \multicolumn{6}{|c|}{ Thessalian fault system } \\
\hline $1941 / 03 / 01$ & 39.67 & 22.54 & 6.3 & Asmaki & \\
\hline $1954 / 04 / 30$ & 39.28 & 22.29 & 7.0 & Ekkara & \\
\hline $1957 / 03 / 08$ & 39.3 & 22.7 & 6.5 & Righeo & \\
\hline $1957 / 03 / 08$ & 39.38 & 22.63 & 6.8 & Righeo? & \\
\hline $1980 / 07 / 09$ & 39.27 & 22.93 & 6.5 & Volos & \\
\hline $1980 / 07 / 09$ & 39.16 & 22.68 & 6.1 & Nea Anchialos & \\
\hline $1985 / 04 / 30$ & 39.26 & 22.89 & 5.6 & Volos & \\
\hline
\end{tabular}

Table 1. Major historical and instrumental earthquakes of the investigated area and their likely causative seismogenic sources, as discussed in the main text [from Papazachos and Papazachou 1997, 2003, Papazachos et al. 2009]. NAB, North Aegean Basin. 
mental seismicity appears to mimic the historical pattern, although the time window is possibly too narrower.

Following the above criticisms and due to the associated uncertainties, any database of seismogenic sources based only on historical and instrumental seismicity would be largely incomplete, and therefore of limited use; e.g. for SHA analyses. Accordingly, we also decided to include in the GreDaSS seismogenic sources recognized on the basis of other criteria, and to use the available data to improve the seismotectonic parameterization of the 'historically'-defined sources [see discussion in Caputo et al. 2008]. In other terms, all of the seismogenic sources included in the database have been recognized, selected and seismotectonically characterized, by appropriately blending the information obtained from the different approaches, methods, data and investigation techniques, like instrumental and historical seismicity, paleoseismological, archeoseismological and morphotectonic studies, and geodetic data on active deformation. All these datasets were opportunely weighted according to the degree of uncertainty attributed to each available piece of information.

Figure 1 shows the seismogenic sources (CSS, ISS and DSS) included at present in the GreDaSS, for roughly north of latitude $39^{\circ} \mathrm{N}$. At first glance, the CSSs and ISSs in Figure 1 that affect this region roughly delineate five sectors: (i) a northern E-W-trending fault belt in Thrace and Eastern Macedonia; (ii) a complex E(SE)-W(NW)-trending fault system that affects the Chalkidiki peninsula and tha is possibly associated with low-angle detachments; (iii) the NE-SWtrending transverse anti-orogenic ('anti-Hellenides') fault system in Western Macedonia and Epirus; (iv) the (E)NE-(W)SW-trending North Aegean Sea fault system, which is almost exclusively located offshore; and (v) the $\mathrm{E}(\mathrm{SE})-\mathrm{W}(\mathrm{NW})$-trending Thessalian fault system. In the following sections, all of the seismogenic sources are synthetically described in terms of their seismotectonic parameters, and their relationships with historical and instrumental earthquakes is discussed. In contrast, the DSSs represented in Figure 1 will be not described and discussed in this report, given that these sources are either too uncertain or that their recent activity is debated.

\section{The northern Greece fault belt}

Northern continental Greece, and particularly Thrace and Eastern Macedonia, are affected by several roughly E-Wtrending normal faults that form an almost continuous regional-scale fault belt that starts from the border with Turkey and extends for more than $300 \mathrm{~km}$ to the Vardar Valley. In the database, there are five CSSs, some of which also contain well-defined segments (ISSs) (Figures 1 and 3; Table 2).

Some historical earthquakes, among which there were the 1784 Komotini, 1829 Drama, and 1829 Xanthi earthquakes (see discussion on magnitudes below; see also Table 1), occurred in this region, and these are examined in the following, together with the causative faults. However, no moderate-to-large earthquakes have hit the area since then, and certainly not during the instrumental period.

We will describe the seismogenic sources from east to west, referring to Figure 3.

\subsection{Maronia CSS}

The Maronia CSS (CSS code, 160) [Chatzipetros and Pavlides 2004, Mountrakis et al. 2006] is a ca. 54-km-long fault zone, striking from E-W to ESE-WNW, dipping to the south, and divided into three segments (not distinguished in Figure 3; see also Table 2) [Chatzipetros and Pavlides 2004]: (i) The Marmaritsa Fault, to the west, that strongly controls the shoreline by creating an impressive $\mathrm{N} 110^{\circ}-120^{\circ}$ striking scarp that is associated with a southwards dipping $\left(55^{\circ}-60^{\circ}\right)$ fault. This segment is characterised by an up to 5 -m-thick brecciation zone, which shows evidence of recent reactivations (e.g. corrugations, striations). (ii) The central Messimvria Fault, striking E-W and dipping southwards $\left(70^{\circ}-75^{\circ}\right)$ mainly ex-

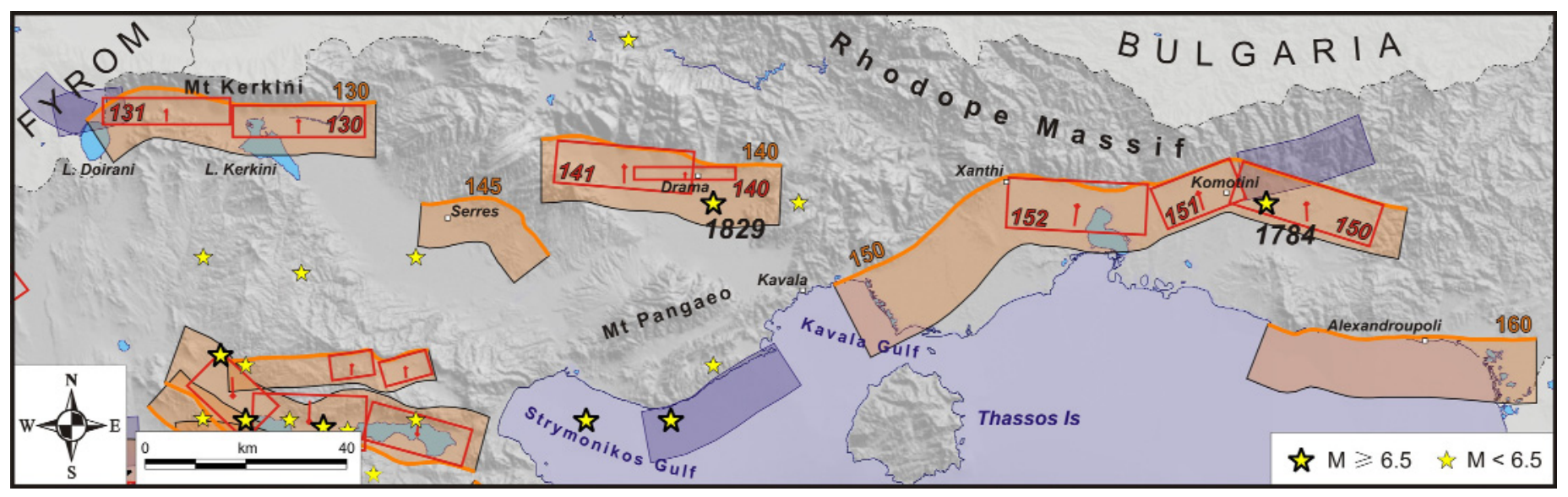

Figure 3. Map detail of the seismogenic sources belonging to the "Northern Greece fault belt". See Figure 1 for map location and seismogenic sources. Three-digit labels refer to the database code of the seismogenic source (ISS codes in italics). Years are provided for major earthquakes discussed in the main text (see also Table 1). 


\begin{tabular}{|c|c|c|c|c|c|c|c|c|c|c|c|c|c|}
\hline $\begin{array}{l}\text { Seismogenic } \\
\text { source }\end{array}$ & Type & Code & $\begin{array}{l}\text { Length } \\
(\mathrm{km})\end{array}$ & $\begin{array}{l}\text { Width } \\
(\mathrm{km})\end{array}$ & $\begin{array}{l}\text { Min. } \\
\text { depth } \\
(\mathrm{km})\end{array}$ & $\begin{array}{l}\text { Max. } \\
\text { depth } \\
(\mathrm{km})\end{array}$ & $\begin{array}{l}\text { Strike } \\
\left(^{\circ}\right)\end{array}$ & $\begin{array}{l}\text { Dip } \\
\left({ }^{\circ}\right)\end{array}$ & $\begin{array}{l}\text { Rake } \\
\left({ }^{\circ}\right)\end{array}$ & $\begin{array}{c}\begin{array}{c}\text { Slip per } \\
\text { event }\end{array} \\
(\mathrm{m})\end{array}$ & $\begin{array}{c}\begin{array}{c}\text { Slip } \\
\text { rate }\end{array} \\
(\mathrm{mm} / \mathrm{a})\end{array}$ & $\begin{array}{c}\text { Recurrence } \\
\text { interval } \\
\text { (ka) }\end{array}$ & $\begin{array}{c}\text { Potential } \\
\mathbf{M}_{w}\end{array}$ \\
\hline Maronia & CSS & 160 & 54.0 & 17.1 & 0 & 14 & $80-120$ & $45-75$ & $230-280$ & 1.56 & $0.4-0.7$ & $\mathrm{n} / \mathrm{a}$ & 7.0 \\
\hline Thrace & CSS & 150 & 123 & 19.5 & 0 & 14 & $40-115$ & $35-75$ & $200-290$ & 1.56 & $0.2-0.5$ & $\mathrm{n} / \mathrm{a}$ & 7.0 \\
\hline Komotini & ISS & 150 & 29.0 & 15.5 & 0 & 12.7 & 108 & 55 & 290 & 0.90 & $\mathrm{n} / \mathrm{a}$ & $\mathrm{n} / \mathrm{a}$ & 6.7 \\
\hline Iasmos & ISS & 151 & 16.7 & 15.5 & 0 & 12.7 & 68 & 55 & 265 & 0.55 & $\mathrm{n} / \mathrm{a}$ & $\mathrm{n} / \mathrm{a}$ & 6.4 \\
\hline Xanthi & ISS & 152 & 27.5 & 16 & 0 & 12.3 & 93 & 50 & 265 & 0.7 & $\mathrm{n} / \mathrm{a}$ & $\mathrm{n} / \mathrm{a}$ & 6.6 \\
\hline Drama & CSS & 140 & 48.1 & 19.9 & 0 & 15.0 & $80-135$ & $40-65$ & $265-280$ & 1.56 & $0.2-0.4$ & $\mathrm{n} / \mathrm{a}$ & 7.0 \\
\hline Prosotsani & ISS & 141 & 27.0 & 15.0 & 0 & 12.3 & 95 & 55 & 275 & 0.70 & $\mathrm{n} / \mathrm{a}$ & $\mathrm{n} / \mathrm{a}$ & 6.6 \\
\hline Drama & ISS & 140 & 20 & 10 & 0 & 9.7 & 90 & 75 & 275 & 0.50 & $\mathrm{n} / \mathrm{a}$ & $\mathrm{n} / \mathrm{a}$ & 6.3 \\
\hline Serres & CSS & 145 & 31.1 & 18.6 & 0 & 16.0 & $80-140$ & $50-80$ & $260-280$ & 1.16 & $0.05-0.1$ & $\mathrm{n} / \mathrm{a}$ & 6.8 \\
\hline Belles & CSS & 130 & 59.3 & 18.6 & 0 & 15.0 & $50-115$ & $45-70$ & $250-280$ & 1.56 & $0.2-0.4$ & $\mathrm{n} / \mathrm{a}$ & 7.0 \\
\hline Petritsi & ISS & 130 & 26.0 & 13.0 & 0 & 11.3 & 90 & 60 & 270 & 0.61 & $\mathrm{n} / \mathrm{a}$ & $\mathrm{n} / \mathrm{a}$ & 6.5 \\
\hline Kastanoussa & ISS & 131 & 25.0 & 13.0 & 0 & 11.8 & 90 & 65 & 270 & 0.60 & $\mathrm{n} / \mathrm{a}$ & $\mathrm{n} / \mathrm{a}$ & 6.5 \\
\hline
\end{tabular}

Table 2. Seismotectonic parameters of the CSSs and ISSs included in the Northern Belt (see Figure 3). CSS, composite seismogenic source; ISS, individual seismogenic source; Code, identification number within the database; $\mathrm{n} / \mathrm{a}$, not available.

tends offshore and is based on the analysis of detailed bathymetric maps. (iii) The eastern Makri Fault, which partially overlaps the Messimvria Fault, and is associated with a group of minor south-dipping sliding planes that affect the young (Late Quaternary?) sediments and marine terraces. The Messimvria Fault is the most active segment of the three above, although the dimensions are insufficient for all to individually produce at least an intermediate event $(M>5.5)$, and therefore they have not been included in the database as ISSs. It is also worth mentioning that the behavior and interactions of the segments have not been sufficiently investigated.

To the west, the Maronia CSS possibly continues offshore, as suggested by bathymetric maps, while to the east, there is the microseismic sequence of June and July, 2004 [Kiratzi et al. 2005], as well as some morphological evidence that suggests that the fault probably extends eastwards to the Evros Valley. By applying the empirical relationship between magnitude and rupture area [Wells and Coppersmith 1994] and considering the total length of the CSS, the maximum expected magnitude is ca. 7.0, which certainly represents the worst case scenario.

\subsection{Thrace CSS (Komotini, Iasmos and Xanthi ISSs)}

This S-dipping tectonic structure (CSS code, 150) is probably more than $120 \mathrm{~km}$ long, and separates the Rhodope Mountain to the north from the Kavala-Xanthi-Komotini basin to the south (Figure 3; Table 2). The strike of the fault trace varies from $40^{\circ}$ to $115^{\circ}$, forming important angular bends. Extensional faulting has occurred since at least the Miocene, and the striations bear evidence of at least three tectonic phases [Lybéris 1984, Lybéris and Sauvage 1985]. The trace has been well mapped by several researchers [Ly- béris 1984, Mountrakis and Tranos 2004, Rondoyanni et al. 2004]. Based on the sea bottom seismic reflection profiles [Martin 1987], the structure probably continues offshore westwards, within the Gulf of Kavala.

This CSS is divided in four major segments [Mountrakis and Tranos 2004, Mountrakis et al. 2006], but only the three easternmost ones show clear morphological evidence of recent activity, which has been classified as ISSs: Komotini (ISS code, 150), Iasmos (ISS code, 151) and Xanthi (ISS code, 152) from east to the west, respectively. The fault barriers between the segments are due to change in strike and dip, generating an overall zig-zag geometry. The dip appears to progressively decrease towards the west [Mountrakis and Tranos 2004, Mountrakis et al. 2006, Rondoyanni et al. 2004]. This probably implies that the maximum depth of the fault zone also progressively decreases westwards, if we assume that the dimensional proportion of the comprised segments remains constant and that the possible listric geometry of the fault plane, which is the usual occasion for the normal faults in the Aegean, should create shallower structures. The slip vectors measured on fault outcrops indicate a generally dip-slip normal kinematics, although oblique-slip displacements prevail locally [Lybéris 1984, Mountrakis and Tranos 2004, Mountrakis et al. 2006, Rondoyanni et al. 2004]. The calculated slip-per-event for each fault segment ranges from 0.55 to $0.90 \mathrm{~m}$. Taking into account the characteristics of the geometrical barriers, and assuming the possibility of a dynamic triggering model, the worst case scenario implies the contemporaneous rupture of more than one segment. The 'softest' barrier (i.e. the easiest to break during an earthquake) is probably the one between the Xanthi and Iasmos segments, which some authors have already described as a unique struc- 
ture [Lybéris 1984, Rondoyanni et al. 2004]. Assuming 44 km of total length, the empirical relationship of magnitude versus rupture area [Wells and Coppersmith 1994] indicates a maximum expected magnitude of 7.0.

The Komotini ISS has been tentatively associated with the 6 November, 1784, earthquake [Papazachos and Papazachou 1997, Mountrakis et al. 2006], although the estimated magnitude (6.7) [Papazachos and Papazachou 1997] might be much lower [e.g. Ambraseys 2009]. Also the more recent 11 April, 1829, Xanthi earthquake is under lively debate. Indeed, Papazachos and Papazachou [1997] considered it as a foreshock of the 5th May, 1829, Drama earthquake (see Drama CSS below), while the description in Ambraseys [2009] suggests that the area near the towm of Xanthi was mainly ruined, in contrast to the area surrounding Drama that was mostly damaged by the second event. If this is the case, it would imply that this 11 April earthquake was not a foreshock of the same seismogenic source, but a distinct event that probably triggered the Drama earthquake ca. one month later. Accordingly, the 11 April, 1829, earthquake has been associated with the Xanthi ISS (Table 1).

\subsection{Drama CSS (Prosotsani and Drama ISSs)}

This is a ca. 48-km-long fault zone (CSS code, 140), with E-W trend, that forms the boundary of the Drama Basin to the north, and consists of two segments: the Prosotsani (ISS code, 141) and Drama (ISS code, 140) ISSs (Figure 3; Table 2). Both of these segments are distinguished, based on detailed morphotectonic mapping [Mountrakis et al. 2006], and they show a right-stepping geometry with significant overlap. Most geometric and kinematic parameters proposed by Mountrakis et al. [2006] are in agreement with the focal mechanism of a moderate event $\left(\mathrm{M}_{\mathrm{w}}=5.2\right)$ that occurred on 9 November, 1986 [Dziewonski et al. 1986, Vannucci and Gasperini 2003, Vannucci and Gasperini 2004]. In particular, where the overlap occurs, both of the segments probably join at depth into a single shallow-angle fault plane. The slip-perevent for each fault segment ranges from $0.5 \mathrm{~m}$ to $0.7 \mathrm{~m}$.

Papazachos and Papazachou [1997] referred to the 5 May, 1829, Drama earthquake as a catastrophic event with a magnitude of 7.3 , which was probably overestimated due to the occurrence of the strong nearby 11 April earthquake (see discussion in Thrace CSS, $\S 3.2$ ). The 5 May event has been associated with the Drama CSS [Mountrakis et al. 2006], but not to any of the two segments. Taking into account the total length of the CSS, a maximum expected magnitude of 7.0 is proposed [Wells and Coppersmith 1994], confirming the overestimate of the 1829 Drama earthquake.

\subsection{Serres CSS}

The Serres fault zone (CSS code, 145) dips to the south and shows slight curvature, with the consequent strike variation from WSW-ENE to NW-SE, from west to east, respec- tively (Figure 3; Table 2) [Tranos and Mountrakis 2004, Mountrakis et al. 2006]. Four segments are suggested for the whole shear zone, although the length of each proposed segment is probably not sufficient to produce at least moderate events; additionally the geometric characteristics of the segment boundaries are not well defined. Accordingly, no specific ISSs have been included in the GreDaSS. The western E-W-trending sector (ca. $20 \mathrm{~km}$ ) shows the most prominent fault trace, while a subtle scarp in Pleistocene deposits continues southeastwards possibly making the total length more than $30 \mathrm{~km}$. Morphotectonic evidence of recent activity is not homogeneous along the strike, and is mainly represented by 7 -m-high fault scarps that affect the Late Pleistocene deposits in the central sector [Tranos and Mountrakis 2004]. No historical or instrumental earthquakes have been associated with this fault zone, although this crustal scale tectonic structure would certainly be capable of generating moderate to strong seismic events, as long as it is optimally oriented with respect to the present-day stress field. It also fills a structural gap between the Drama CSS to the east and the Belles CSS to the west, thus contributing to the regional N-S lithospheric stretching that affects the Southern Aegean.

\subsection{Belles CSS (Petritsi and Kastanoussa ISSs)}

Belles CSS (CSS code 130) is an almost 60-km-long fault zone that borders an impressive linear mountain front and is characterized by thick multi-generation alluvial fans that have accumulated in the hanging-wall block (Figure 3; Table 2) [Psilovikos and Papaphilippou 1990, Mariolakos et al. 2004, Pavlides et al. 2004a]. The whole Mount Kerkini (commonly referred to as Belles) represents the natural border between Greece and Bulgaria, and is considered as a recent tectonic horst by Psilovikos [1984]. On the basis of morphotectonic mapping and morphometric analyses, the fault zone was active during the Quaternary and especially the Holocene, while the observed striations are mechanically compatible with the present-day extensional stress field [Pavlides et al. 2004a].

Mountrakis et al. [2006] separated the fault zone into two major segments that have been approximately adopted in the database: the Petritsi (ISS code, 130) and Kastanoussa (ISS code, 131) ISSs, to the east and west, respectively. Both segments have similar lengths $(25-26 \mathrm{~km}$ each) and a slight right-stepping geometrical relationship. Lateral variations in the degree of activity are debated. For example, based on several geomorphic features (well-developed fault scarps with accelerated erosion, deposition of younger generations of alluvial fans upon older fan heads close to the fault zone, more extensive fan deposits, slightly entrenched torrents and much higher elevations of the fan heads), Psilovikos and $\mathrm{Pa}$ paphilippou [1990] suggested a higher activity on the western portion of the fault, while based on the deflection of the Strymon River [Pavlides et al. 2004a, Mariolakos et al. 2004] and the low value of the mountain front sinuosity index, the 
eastern sector was suggested to be more active.

No major historical earthquakes are reported in the catalogs. It is of note that immediately N-NW of Lake Doirani there was an instrumentally recorded seismic sequence (MayOctober 2009), with a $M_{w}=5.2$ event as the strongest shock [Kiratzi 2010]. This suggests the presence of an antithetic NNEdipping normal fault. This implies that the Belles CSS probably comes to an end close to the Greece-FYROM border.

According to empirical relationships, the mean displacement for each segment is $0.60 \mathrm{~m}$, and the maximum expected magnitude is 6.5 for both the Kastanoussa and Petritsi ISSs. Due to the limited separation between the two segments, a combined rupture (worst-case scenario) is highly possible, and could produce a larger event (ca. $\mathrm{M}=7.0$ ).

\section{The Chalkidiki fault system}

The active faults that affect the Chalkidiki peninsula (Figure 4; Table 3) are grouped separately from the northern E-W-trending fault belt, due to their slightly different mean orientation, which is ESE-WNW, but especially because they form two fault systems that consist of closely spaced, subparallel, synthetic, highly dipping normal faults that are possibly linked at depth by a low-angle shear zone [Sboras and Caputo 2010]. The eastern fault system is mainly SSW-dipping, while the western one is NNE-dipping. Both fault systems are delimited by an antithetic structure, to the south and north, respectively, which are also included in the database. The eastern system is formed by the Stratoni-Varvara, Gomati and Singitikos GulfCSSs and the Vourvourou ISS, while the western system of faults is formed by the Sochos-Mavrouda, Mygdonia, Asvestochori, Pylaea and Anthemountas CSSs.

In the area (Figure 4), three major earthquakes have occurred during historical and recent times (1932 Ierissos; 1978 Thessaloniki; May 11, 1933, Thessaloniki; see Table 1). For the former two events, the causative fault is well established, while the latter has been tentatively associated with the Gomati CSS. All of these will be discussed in the following paragraphs. However, several moderate events are listed as prior to the 20th century in the historical catalogs [Papazachos and Papazachou 1997, Ambraseys 2009]. For example, in the western Mygdonia Basin the following events have been reported [Papazachos and Papazachou 1997]: (i) in 700 AD, with $\mathrm{M}_{\mathrm{e}}=6.5$, which is characterized as a 'spurious' event according to Ambraseys [2009]; (ii) in July, $1420\left(\mathrm{M}_{\mathrm{e}}=6.0\right)$, there was a quite destructive event for the city of Thessaloniki [Ambraseys 2009]; and (iii) on March $261430\left(\mathrm{M}_{\mathrm{e}}=\right.$ 6.0), there was an event that caused some damage to the city walls [Ambraseys 2009]. For the eastern part of the basin, only one event of magnitude 6.4 was reported in the catalogue of Papazachos and Papazachou [1997], in the year 677 AD, but this was considered 'spurious' by Ambraseys [2009]. The available historical information for all of these events, however, is not sufficient to accurately locate the epicenters or to estimate the real magnitudes, and therefore to associate them to any specific causative fault(s).

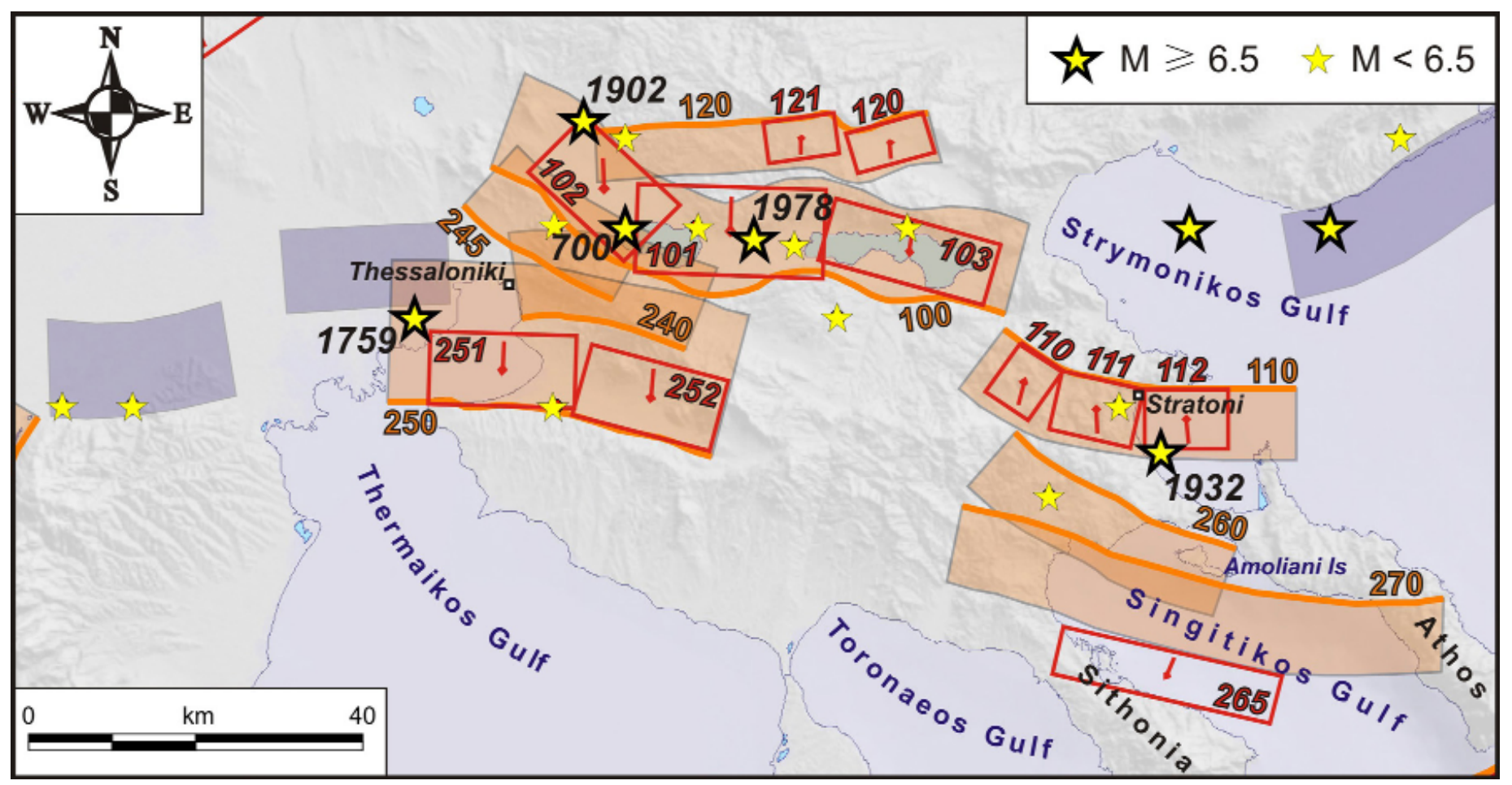

Figure 4. Map detail of the seismogenic sources belonging to the "Chalkidiki fault system". See Figure 1 for map location and seismogenic sources. Three-digit labels refer to the database code of the seismogenic source (ISS codes in italics). Years are provided for major earthquakes discussed in the main text (see also Table 1). 


\begin{tabular}{|c|c|c|c|c|c|c|c|c|c|c|c|c|c|}
\hline $\begin{array}{l}\text { Seismogenic } \\
\text { source }\end{array}$ & Type & Code & $\begin{array}{l}\text { Length } \\
(\mathrm{km})\end{array}$ & $\begin{array}{l}\text { Width } \\
(\mathrm{km})\end{array}$ & $\begin{array}{l}\text { Min. } \\
\text { depth } \\
(\mathrm{km})\end{array}$ & $\begin{array}{l}\text { Max. } \\
\text { depth } \\
(\mathrm{km})\end{array}$ & $\begin{array}{l}\text { Strike } \\
\left({ }^{\circ}\right)\end{array}$ & $\begin{array}{l}\text { Dip } \\
\left({ }^{\circ}\right)\end{array}$ & $\begin{array}{l}\text { Rake } \\
\left({ }^{\circ}\right)\end{array}$ & $\begin{array}{c}\text { Slip per } \\
\text { event } \\
(\mathrm{m})\end{array}$ & $\begin{array}{c}\text { Slip } \\
\text { rate } \\
(\mathrm{mm} / \mathrm{a})\end{array}$ & $\begin{array}{c}\text { Recurrence } \\
\text { interval } \\
\text { (ka) }\end{array}$ & $\begin{array}{c}\text { Potential } \\
\mathrm{M}_{\mathrm{w}}\end{array}$ \\
\hline Stratoni-Varvara & CSS & 110 & 37.0 & 18.0 & 0 & 17.0 & $85-130$ & $65-85$ & $270-290$ & 1.56 & $0.3-1.1$ & $\mathrm{n} / \mathrm{a}$ & 7.0 \\
\hline Varvara & ISS & 110 & 6.2 & 17.0 & 0.5 & 15.9 & 124 & 65 & 290 & 0.33 & & & 6.0 \\
\hline West Stratoni & ISS & 111 & 10.0 & 17.5 & 0 & 15.9 & 103 & 65 & 285 & 0.43 & & & 6.2 \\
\hline East Stratoni & ISS & 112 & 10.0 & 17.5 & 0 & 15.9 & 90 & 65 & 275 & 0.43 & & & 6.2 \\
\hline Gomati & CSS & 260 & 30.6 & 17.3 & 0 & 16 & $110-135$ & $60-85$ & $300-325$ & 1.0 & $0.3-0.8$ & $\mathrm{n} / \mathrm{a}$ & 6.7 \\
\hline Singitikos Gulf & CSS & 270 & 59.7 & 19.6 & 0 & 16.0 & $90-130$ & $45-75$ & $280-320$ & 1.56 & $0.6-0.7$ & $\mathrm{n} / \mathrm{a}$ & 7.0 \\
\hline Vourvourou & ISS & 265 & 27.0 & 14.0 & 0 & 12.7 & 283 & 65 & 260 & 0.63 & & & 6.6 \\
\hline Sochos-Mavrouda & CSS & 120 & 41.1 & 16.2 & 0 & 15.0 & $70-100$ & $60-85$ & $260-280$ & 0.86 & $0.1-0.8$ & $\mathrm{n} / \mathrm{a}$ & 6.6 \\
\hline Sochos & ISS & 121 & 8.5 & 15.0 & 0 & 14.1 & 82 & 70 & 260 & 0.36 & & & 6.1 \\
\hline Mavrouda & ISS & 120 & 9.5 & 15.0 & 0 & 14.1 & 74 & 70 & 255 & 0.39 & & & 6.1 \\
\hline Mygdonia & CSS & 100 & 68.6 & 25.6 & 0 & 17.0 & $250-320$ & $30-80$ & $250-315$ & 0.86 & $0.1-0.5$ & $\mathrm{n} / \mathrm{a}$ & 6.6 \\
\hline Apollonia & ISS & 103 & 20.5 & 18.5 & 0 & 16.8 & 286 & 65 & 280 & 0.65 & & & 6.6 \\
\hline Gerakarou & ISS & 101 & 22.5 & 17.0 & 0 & 13.0 & 272 & 50 & 270 & 0.60 & $0.1-0.7$ & $1-1.5$ & 6.5 \\
\hline Langhadas & ISS & 102 & 16 & 15 & 0 & 11.5 & 314 & 50 & 315 & 0.51 & & & 6.4 \\
\hline Asvestochori & CSS & 245 & 21.5 & 22.1 & 0 & 16.0 & $280-320$ & $35-80$ & $270-300$ & 0.55 & $0.1-0.4$ & $\mathrm{n} / \mathrm{a}$ & 6.3 \\
\hline Pylaea & CSS & 240 & 20.3 & 22.5 & 0 & 16.0 & $260-295$ & $35-70$ & $260-280$ & 0.35 & $0.1-0.4$ & $\mathrm{n} / \mathrm{a}$ & 6.0 \\
\hline Anthemountas & CSS & 250 & 40.0 & 30.0 & 0 & 20.0 & $265-295$ & $30-85$ & $260-290$ & 1.56 & $0.1-0.5$ & $\mathrm{n} / \mathrm{a}$ & 7.0 \\
\hline Souroti & ISS & 252 & 17 & 18.0 & 0 & 15.6 & 285 & 60 & 280 & 0.58 & & & 6.5 \\
\hline Angelochori & ISS & 251 & 17.5 & 18 & 0 & 15.6 & 272 & 60 & 270 & 0.59 & & & 6.5 \\
\hline
\end{tabular}

Table 3. Seismotectonic parameters of the CSSs and ISSs included in the Chalkidiki fault system (see Figure 4). CSS, composite seismogenic source; ISS, individual seismogenic source; Code, identification number within the database; n/a, not available.

\subsection{Stratoni-Varvara CSS (Varvara, West Stratoni and East} Stratoni ISSs)

The Stratoni-Varvara CSS (CSS code, 110) is a S-SWdipping fault zone that affects the eastern coast of Chalkidiki peninsula, bordering the south side of Mount Stratoniki and largely continuing offshore (Figure 4; Table 3). This CSS was ruptured on September 26, 1932, with a strong 'linear morphogenic event' [sensu Caputo 2005] with magnitude 7.0 [Papazachos and Papazachou 1997] or 6.9 [Ambraseys and Jackson 1998] (Table 1). Co-seismic effects were plentiful enough to confirm that the Stratoni-Varvara CSS was the causative tectonic structure. Ground ruptures [Floras 1933], many of which coincided with the mapped geological fault, were preserved even decades afterwards [Pavlides and Tranos 1991]. A coastal subsidence of $1.6 \mathrm{~m}$ [reported by Floras 1933, from Pavlides and Tranos 1991] and a downthrow of approximately $1.8 \mathrm{~m}$ across the fault scarp can be inferred from photographic archives [e.g. Georgalas and Galanopoulos 1953].

Although the co-seismic ruptures and the large instrumentally recorded magnitude suggest that the 1932 event ruptured the largest portion of the fault surface, morpho- tectonic investigations indicate that the Stratoni-Varvara CSS is segmented into three parts that show independent seismotectonic evolution [Chatzipetros et al. 2005, Michailidou et al. 2005, Pavlides et al. 2010]. The Varvara ISS (ISS code, 110 ) is the westernmost segment, is $6.5 \mathrm{~km}$ long and probably consists of several parallel sliding planes with a general WNW-ESE strike. It forms an angular barrier with the adjacent West Stratoni ISS (ISS code, 111). The last segment (East Stratoni ISS; ISS code, 112) runs mainly offshore and clearly controls the E-W trending coastline up to Eleftheronesos Island $(10 \mathrm{~km})$. Based on the observed maximum displacement documented near Stratoni that was caused by the 1932 Ierissos earthquake [Floras 1933, Georgalas and Galanopoulos 1953, Pavlides and Caputo 2004], the CSS probably continues further eastwards, thus resulting in a total length of ca. $37 \mathrm{~km}$. Field measurements along the fault trace [Pavlides and Tranos 1991] and the microseismicity distribution at depth [Galanis et al. 2004] indicate a steeply dipping fault plane. On the basis of the available seismological information, the maximum depth of the structure is likely to be 16$18 \mathrm{~km}$. The calculated values of the mean co-seismic 
displacement for these three segments range from $0.33 \mathrm{~m}$ to $0.43 \mathrm{~m}$, while for the whole CSS this value might be as high as $1.56 \mathrm{~m}$. The 1932 event $(\mathrm{M}=6.9-7.0)$ probably corresponds to the worst-case scenario, and represents the maximum expected magnitude for this CSS.

\subsection{Gomati CSS}

Roughly parallel to and synthetic with the Stratoni-Varvara CSS, there is the Gomati fault zone (CSS code, 260; Figure 4; Table 3). The available information is generally scant and the uncertainty is consequently high for many parameters. Mainly based on morphotectonic investigations and meso-structural analyses [Pavlides and Kilias 1987, Chatzipetros et al. 2005, Michailidou et al. 2005], this tectonic structure is characterized by a major linear escarpment, striking $110^{\circ}-135^{\circ}$ and dipping ca. $65^{\circ}$ towards the SSW. Field observations of slickenlines indicate a rake of $300^{\circ}-325^{\circ}$ [Pavlides and Kilias 1987]. The three-dimensional relocation of a set of earthquakes to the Chalkidiki peninsula [Galanis et al. 2004], indicate seismogenic depths down to $16-17 \mathrm{~km}$ for this zone, while a relocated seismic cluster suggests eastwards continuation of the fault zone offshore and north of Amoliani Island [Galanis et al. 2004], thus defining a total length of ca. $30 \mathrm{~km}$.

In concomitance with the 1932 Ierissos seismic crisis, a large number of strong foreshocks and aftershocks were also recorded in the broader area [Papazachos and Papazachou 1997]. It is usually assumed that the magnitude $M=6.3$ event that occurred on May 11, 1933, belongs to this seismic sequence and represents an aftershock of the Ierissos mainshock. However, based on a recent relocation of this event several kilometers southwards [Papazachos et al. 2009], and taking into account the long time period that has elapsed since the main shock, we tentatively associate the 1933 event with the Gomati CSS, which was partly reactivated due to a triggering effect. The maximum expected magnitude for the Gomati CSS obtained from empirical relationships is 6.7 [Wells and Coppersmith 1984].

\subsection{Singitikos Gulf CSS}

The Singitikos Gulf CSS (CSS code, 270) belongs to the same system of SSW-dipping normal faults that affect the eastern sector of the Chalkidiki peninsula (Figure 4; Table 3). However, its total length is double than the Gomati CSS, and also greater than the Stratoni-Varvara CSS. The onshore part of this tectonic structure has been morphotectonically mapped [Pavlides and Kilias 1987], and shows oblique-slip kinematics with normal and left-lateral components. On the basis of detailed bathymetric maps, the CSS probably continues offshore, running south of the Amoliani Island and generating the E-W-trending coastal escarpment in the Athos Peninsula. It possibly continues eastwards across the Athos Peninsula, although specific field investigations have not been carried out. Information is also scant as concerns possible segmentation. Assuming the worst-case scenario, a maximum expected magnitude of 7.0 can be estimated from the empirical relationship of Wells and Coppersmith [1994].

\subsection{Vourvourou ISS}

The southernmost structure of the east Chalkidiki peninsula fault system is represented by the Vourvourou ISS (ISS code, 265) (Figure 4; Table 3) [Tranos 1998, Mountrakis et al. 2006], which was also referred to as Sithonia Fault by Goldsworthy et al. [2002]. Although the strike of the fault is similar (ESE-WNW), this ISS is north-dipping, which is antithetic with respect to the Singitikos, Gomati and StratoniVarvara CSSs. Morphotectonic investigations and mesostructural analyses across the Sithonia peninsula [Tranos 1998] documented a Quaternary activity for ca. $15 \mathrm{~km}$ and the occurrence of two minor segments, but they are too small to generate moderate events. The assumed total length of the seismogenic structure is $27 \mathrm{~km}$. The calculated slipper-event of the Vourvourou ISS is $0.63 \mathrm{~m}$, while the maximum expected magnitude obtained from empirical relationships is 6.6 [Wells and Coppersmith 1994].

\subsection{Sochos-Mavrouda CSS (Sochos and Mavrouda ISSs)}

As mentioned above, another important fault system that consists of several subparallel and largely overlapping CSSs affects the central-western sector of the Chalkidiki peninsula (Figure 4; Table 3). The northernmost structure, north of Mygdonia Basin, is the Sochos-Mavrouda CSS (CSS code, 120), which is antithetic with respect to the other ones, as it is the only south-dipping structure. This fault zone is ca. $41 \mathrm{~km}$ long, and forms small intra-mountain basins [Maravelakis 1936]. Its activity was constrained on the basis of morphotectonic analysis of the mountain front and of the thick Quaternary scree and fan sediments accummulated in the hanging-wall [Mountrakis et al. 1996a, 2006]. At least two ca. 9-km-long segments have been recognized: the Sochos (ISS code, 121) and Mavrouda (ISS code, 120) ISSs [Goldsworthy et al. 2002, Mountrakis et al. 2006]. The segment boundary is represented by a marked gap, with a right-stepping underlapping geometry; this therefore makes a continuous rupture unlikely. Based on their length, each of the two segments is considered capable of producing a maximum earthquake of magnitude 6.1 [Wells and Coppersmith 1994], while in the case of a complete reactivation of the western sector (ca. 29 $\mathrm{km}$ ), the maximum expected magnitude is 6.6 [Wells and Coppersmith 1994]. The westernmost section of the fault zone is characterized by microseismic activity [Galanis et al. 2004, Paradisopoulou et al. 2004]. According to three-dimensional re-location of the local seismicity [Galanis et al. 2004], the thickness of the seismogenic layer is ca. $13 \mathrm{~km}$ to $15 \mathrm{~km}$. The Sochos-Mavrouda CSS is a possible candidate for the July 5, 1902, Assiros earthquake $(\mathrm{M}=6.5)$ [Papazachos 
and Papazachou 1997] (Table 1), although we have tentatively attributed this event to the Langadhas ISS (see Mygdonia CSS), according to a critical revision of the available historical information. ISSs)

4.6. Mygdonia CSS (Apollonia, Gerakarou and Langadhas

South of the Sochos-Mavrouda CSS, but with an antithetic north-dipping setting, there is the major Mygdonia CSS (CSS code, 100), which borders the homonymous basin to the south, for a total length of ca. $69 \mathrm{~km}$ (Figure 4; Table 3). The fault trace follows the mountain front and shows important strike variations due to segmentation. The fault zone was first mapped by Kockel and Mollat [1977], but most structural and morphotectonic investigations were carried out after the June 20,1978 , Thessaloniki earthquake $\left(M_{w}=6.5\right.$; Table 1$)$, which re-activated the central segment of the Mygdonia CSS [Mercier et al. 1979, Mercier et al. 1983, Mountrakis et al. 1996a, Tranos et al. 2003]. Three main segments can be recognized (from east to west): the Apollonia, Gerakarou and Langadhas ISSs.

The eastern Apollonia Fault segment (ISS code, 103) has sculptured a prominent linear morphology, which is interrupted by the alluvial fan of the Megalo Rema. A conservative value for the fault length is $20 \mathrm{~km}$, and the segment boundary with the Gerakarou Fault to the west is marked by a change in strike. Microearthquake surveys document dipslip motion on the Apollonia ISS [Hatzfeld et al. 1986/87], while the three-dimensional relocation of the seismicity shows activity down to a depth of $18 \mathrm{~km}$, and delineates a steeply dipping fault plane [Galanis et al. 2004]. Based on empirical relationships [Wells and Coppersmith 1994], the potential amount of slip per event is $0.65 \mathrm{~m}$, while 6.5 is the maximum expected magnitude.

The central sector of the CSS is represented by the Gerakarou ISS (ISS code, 101), which was the causative fault of the 1978 earthquake. This earthquake has been thoroughly studied due to its location very close to Thessaloniki city. Extended co-seismic ground ruptures were produced that splayed out in the Mygdonia Basin [Mercier et al. 1979, Papazachos et al. 1979, Soufleris and Stewart 1981, Mercier et al. 1983, Mountrakis et al. 1996a]. The most significant ruptures occurred along the southern margin of the basin, coinciding with the principal $\mathrm{N}$-dipping fault escarpment. Two other groups of aligned ruptures were observed near to the center of the basin, between lakes Koronia and Volvi. In particular, the northernmost rupture strikes NW-SE and shows a south-dipping normal displacement, and it probably represents a secondary accommodation structure. The seismotectonic parameters are well constrained on the basis of focal mechanisms, source parameters of the mainshock, and the aftershock distribution [Kulhánek and Meyer 1979, Papazachos et al. 1979, Barker and Langston 1981, Carver and Bollinger 1981, Soufleris and Stewart 1981, Soufleris et al.
1982, Soufleris and King 1983, Dziewonski et al. 1987, Vannucci and Gasperini 2003, Vannucci and Gasperini 2004, Roumelioti et al. 2007], as well as several morphotectonic investigations and meso-structural analyses [Mercier et al. 1979, Mercier et al. 1983, Mountrakis et al. 1996a, Tranos et al. 2003]. The ruptured fault plane strikes almost E-W, dips northwards with a shallow to moderate angle, and is characterized by an almost pure dip-slip normal motion associated with a N-S direction of crustal extension. Microearthquake surveys suggest listric fault geometry with a plane kink at 8 $\mathrm{km}$ in depth and a seismogenic layer thickness between $14 \mathrm{~km}$ and $16 \mathrm{~km}$ [Hatzfeld et al. 1986/87, Tranos et al. 2003, Paradisopoulou et al. 2006], which is shallower with respect to the eastern segment. Stiros and Drakos [2000] suggested blind faulting during the 1978 event, considering that the observed surface ruptures were only secondary effects. In contrast, paleoseismological trenches confirm the occurrence of repeated linear morphogenic events before the 1978 earthquake [Cheng et al. 1994, Chatzipetros 1998, Chatzipetros et al. 2004], with a mean slip per event of $0.7 \mathrm{~m}$ to $1.6 \mathrm{~m}$, a slip-rate of $0.1 \mathrm{~mm} / \mathrm{a}$ to $0.7 \mathrm{~mm} / \mathrm{a}$, and a recurrence interval between $1.0 \mathrm{ka}$ and $1.5 \mathrm{ka}$. If we rely on the magnitude scaling relationships of the database, the slip per event at the fault scale is probably overestimated; therefore, we prefer the suggested value of $0.6 \mathrm{~m}$ [Roumelioti et al. 2007], which is based on seismic waveform joint inversion and levelling data.

The westernmost segment (Langadhas ISS; ISS code, 102) borders a sharp mountain front with NW-SE trending. Although this structure has been clearly inherited from previous tectonic events (both alpine thrusting and MiocenePliocene NE-SW extension) and it is not ideally oriented with the present-day regional stress field, it shows evidence of recent reactivation, with oblique-slip kinematics [Mercier et al. 1979, 1983], as also supported by morphometric parameters (very low mountain-front sinuosity index). In contrast, Tranos et al. [2003] suggested that this portion of the Mygdonia CSS has been abandoned and that the activity has migrated to the south, towards the Asvestochori CSS (see \$4.7). Microseismic activity [Galanis et al. 2004, Paradisopoulou et al. 2006] indicates a maximum depth of $14 \mathrm{~km}$ to $16 \mathrm{~km}$. The calculated mean displacement is $0.51 \mathrm{~m}$, and the maximum expected magnitude is 6.4 [Wells and Coppersmith 1994]. As mentioned above, and according to the available historical information, the July 5, 1902, Assiros earthquake $(M=6.5)$ [Papazachos and Papazachou 1997] has been tentatively attributed to the Langadhas ISS.

\subsection{Asvestochori CSS}

This fault zone (CSS code, 245) lies very near to the urban area of Thessaloniki. It runs parallel to, and is synthetic with, the western segment of the Mygdonia CSS (Figure 4; Table 3). The fault is reported in several morphotectonic and geological maps [Mountrakis et al. 1996a, Mountrakis et al. 1996b, 
Tranos et al. 2003, Zervopoulou 2004]. According to Mercier et al. [1983], the Asvestochori Fault was partially reactivated during the 1978 Thessaloniki earthquake. According to Tranos et al. [2003], the recent growth of this structure has progressively shadowed the Langadhas ISS and is going to produce a direct linkage with the central sector of the Mygdonia CSS. Information on the deeper parts of the fault has been provided by microearthquake investigations [Paradisopoulou et al. 2006] and geological considerations [Tranos et al. 2003], both of which imply a listric geometry with a dip varying from $80^{\circ}$ at the surface, to $35^{\circ}$ at depth. The maximum seismogenic depth is constrained between 15 and $16 \mathrm{~km}$, based on microseismic distribution [Galanis et al. 2004, Paradisopoulou et al. 2004].

\subsection{Pylaea CSS}

This seismogenic structure (CSS code, 240) is important because it directly crosses the urban area of Thessaloniki and its gulf (Figure 4; Table 3). The fault trace was mapped by Mountrakis et al. [1996b], Tranos et al. [2003], Zervopoulou [2004] and Valkaniotis et al. [2005], who provided constraints on its location, surface geometry, and strike. Considering that this tectonic structure belongs to the broader normal fault system that affects the central-western Chalkidiki peninsula and that it possibly represents an upwards splay of a deeper low-angle normal detachment [Tranos et al. 2003], the other principal seismotectonic parameters have been inferred accordingly. The extension of this fault towards the West to the city of Thessaloniki was mapped as the Voulgari Street Fault by Zervopoulou [2009], who also proposed a maximum expected magnitude of 6.0 .

\subsection{Anthemountas CSS (Souroti and Angelochori ISSs)}

The Anthemountas Fault (CSS code, 250) [Mountrakis et al. 1993b] is also an important structure for the Thessaloniki urban area, because it bounds the southern side of the Thermaikos Gulf and has been mapped for a total length of at least $40 \mathrm{~km}$ (Figure 4). It possibly extends more to the west, as offshore in the gulf. According to Tranos et al. [2003], this structure represents the southernmost north-dipping steepsplay fault which joins at depth a regional-scale low-angle extensional shear zone that is kinematically linked to the Pylaea, Asvestochori and Mygdonia CSSs. The fault has been tentatively separated into two segments according to morphotectonic criteria [Zervopoulou 2004, Zervopoulou and Pavlides 2005, Zervopoulou et al. 2007]: the Souroti (ISS code, 252) and Angelochori (ISS code, 251) ISSs; east and west, respectively, with both characterized by a length of ca. $17 \mathrm{~km}$.

In 1759, an important seismic sequence affected the city of Thessaloniki [Papazachos and Papazachou 1997, Ambraseys 2009] (Table 1). The date of the major shock is still debated. Papazachos and Papazachou [1997] suggest June 22, while Ambraseys [2009] stated that on June 22, two 'violent' shocks indeed occurred, but the destructive event took place on the July 3. The macroseismic magnitude was 6.5 , and the aftershock sequence was intensive [Papazachos and Papazachou 1997]. According to the tentative location of the macroseismic epicentre, the causative fault might be the Angelochori ISS. In 1677, another earthquake with an estimated macroseismic magnitude of 6.2 caused damage in several villages east of Thessaloniki [Papazachos and Papazachou 1997, Ambraseys 2009] (Table 1). Based on the suggested macroseismic epicenter and considering that ca. 80 years later the western segment was probably reactivated (the 1759 event), this 1677 earthquake is tentatively associated with the Souroti ISS (eastern segment). It is of note that aseismic creep has been observed along the Angelochori Fault [Zervopoulou et al. 2007]. Assuming an independent rupture of the two segments, the calculated mean displacement is ca. $0.6 \mathrm{~m}$, and the suggested maximum expected magnitude is 6.5 [Valkaniotis et al. 2005], which become $1.56 \mathrm{~m}$ and $\mathrm{M}=7.0$ in the worst-case scenario (i.e. entire fault rupture).

\section{The 'anti-Hellenides' fault system}

West of Vardar Valley, in western Macedonia and Epirus, the orographic and morphological first-order texture of the region is characterized by the NW-SE-trending Hellenic fold-and-thrust belt that has generated elongated mountain chains and interposed valleys (Figure 5; Table 4). In this sector of northern Greece, all of the major active faults that have been recognized at present and that are included in GreDaSS are oriented NE-SW, and therefore show the typical 'anti-Hellenides' (anti-orogenic) setting. It is worth noting that stress trajectories reconstructed for this region show a NNW to NW orientation of the $\sigma_{3}$ stress axis [e.g. Mercier et al. 1989, Jenny et al. 2004].

Within this fault system, the GreDaSS includes several 'isolated' CSSs and ISSs, like North Almopia, South Almopia, Goumenissa, Aliakmonas, Konitsa and Petoussi. In contrast, the Ptolemaida Basin is affected by a group of sub-parallel, synthetic and antithetic, seismogenic structures that are possibly linked at depth by a low-angle shear zone, which shows a seismotectonic setting that is similar to that described for the Chalkidiki peninsula [Sboras and Caputo 2010].

\subsection{North Almopia CSS (Pozar, Promachi and Aetochori ISSs)}

The North Almopia fault zone (CSS code, $\mathbf{0 6 0}$ ) has a total length of ca. $41 \mathrm{~km}$, and bounds the northern margin of Almopia Basin and a smaller adjacent basin to the northeast (Figure 5; Table 4) [Pavlides et al. 1990, Goldsworthy et al. 2002, Vougioukalakis 2002, Mountrakis et al. 2006]. The development of Almopia Basin took place during the Pliocene and was accompanied by significant volcanic activity [Mercier 1981]. Vougioukalakis [2002], however, suggested that the subsidence of the basin occurred only after the end of the volcanism (1.8 Ma); i.e. during the Quaternary. 


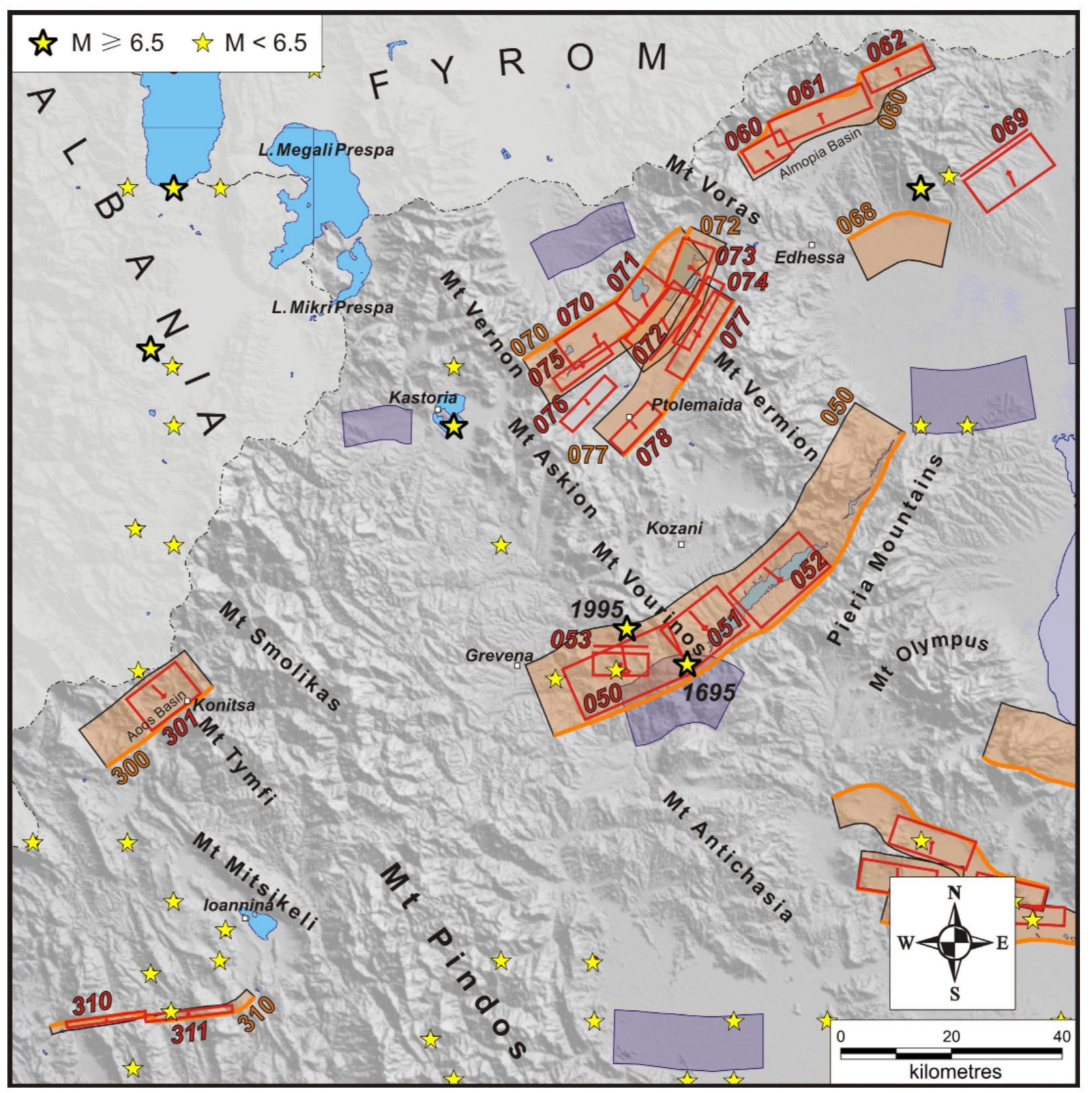

Figure 5. Map detail of the seismogenic sources belonging to the "anti-Hellenides fault system". See Figure 1 for map location and seismogenic sources. Three-digit labels refer to the database code of the seismogenic source (ISS codes in italics). Years are provided for major earthquakes discussed in the main text (see also Table 1).

This zone can be divided into three major segments [Goldsworthy et al. 2002, Mountrakis et al. 2006]: the Pozar (ISS code, 060), Promachi (ISS code, 061) and Aetochori (ISS code, 062) ISSs (from west to east), which form an overall leftstepping geometry. Meso-structural analyses have provided important geometric and kinematic information [Mercier et al. 1989, Pavlides et al. 1990] indicating that two slightly different extensional tectonic phases took place from the Middle Pleistocene to the present, with the most recent stress field characterized by a NNW-SSE direction of extension. Using electrical resistivity tomography, borehole data, and field observations, Vougioukalakis [2002] carried out a three-dimensional structural reconstruction of the basin, and estimated the vertical and horizontal extension rates for the central sector of $0.92 \mathrm{~mm} / \mathrm{a}$ and $0.36 \mathrm{~mm} / \mathrm{a}$, respectively. The calculated slip per event and maximum expected magnitude for the three segments are (from east to west) $0.36 \mathrm{~m}, 0.47 \mathrm{~m}$ and $0.30 \mathrm{~m}$, and 6.1, 6.3 and 5.9, respectively. However, the worstcase scenario considers the joint reactivation of the two western segments (the Pozar and Promachi ISSs), with a maximum expected magnitude, according to empirical relationships [Wells and Coppersmith 1994], of 6.6, given that the Aetochori ISS shows a great overstep and underlap, which would probably act as a strong barrier.

\subsection{Goumenissa ISS}

Information for this seismogenic structure (CSS code, 069) mainly derives from the December $21,1990\left(M_{s}=6.0\right)$ Goumenissa earthquake [Panagiotopoulos et al. 1993]. The fault evidence at the surface is somewhat questionable; the 


\begin{tabular}{|c|c|c|c|c|c|c|c|c|c|c|c|c|c|}
\hline $\begin{array}{l}\text { Seismogenic } \\
\text { source }\end{array}$ & Type & Code & $\begin{array}{c}\text { Length } \\
(\mathrm{km})\end{array}$ & $\begin{array}{l}\text { Width } \\
(\mathrm{km})\end{array}$ & $\begin{array}{l}\text { Min. } \\
\text { depth } \\
(\mathrm{km})\end{array}$ & $\begin{array}{l}\text { Max. } \\
\text { depth } \\
(\mathrm{km})\end{array}$ & $\begin{array}{l}\text { Strike } \\
\left(^{\circ}\right)\end{array}$ & $\begin{array}{l}\text { Dip } \\
\left({ }^{\circ}\right)\end{array}$ & $\begin{array}{l}\text { Rake } \\
\left({ }^{\circ}\right)\end{array}$ & $\begin{array}{c}\begin{array}{c}\text { Slip per } \\
\text { event }\end{array} \\
\text { (m) }\end{array}$ & $\begin{array}{c}\text { Slip } \\
\text { rate } \\
(\mathrm{mm} / \mathrm{a})\end{array}$ & $\begin{array}{c}\text { Recurrence } \\
\text { interval } \\
(\mathrm{ka})\end{array}$ & $\begin{array}{l}\text { Potential } \\
\mathbf{M}_{\mathrm{w}}\end{array}$ \\
\hline North Almopia & CSS & 060 & 41.2 & 13 & 0 & 12.0 & $50-85$ & $60-85$ & $230-290$ & 0.86 & $0.2-0.6$ & $\mathrm{n} / \mathrm{a}$ & 6.6 \\
\hline Pozar & ISS & 060 & 8.0 & 11.0 & 0 & 10.0 & 60 & 65 & 285 & 0.30 & & & 5.9 \\
\hline Promachi & ISS & 061 & 18.2 & 11.5 & 0 & 10.4 & 67 & 65 & 270 & 0.47 & & & 6.3 \\
\hline Aetochori & ISS & 062 & 12.0 & 10.0 & 0 & 9.1 & 65 & 65 & 270 & 0.36 & & & 6.1 \\
\hline Goumenissa & ISS & 069 & 14 & 12.5 & 1.0 & 11.2 & 54 & 55 & 257 & 0.34 & & & 6.1 \\
\hline South Almopia & CSS & 068 & 20.1 & 19.8 & 0 & 16.0 & $45-75$ & $45-70$ & $245-265$ & 0.55 & $0.2-0.4$ & $\mathrm{n} / \mathrm{a}$ & 6.3 \\
\hline Amyndeo & CSS & 070 & 38.2 & 16.1 & 0 & 13.0 & $30-65$ & $45-70$ & $250-270$ & 0.86 & $0.1-0.3$ & $\mathrm{n} / \mathrm{a}$ & 6.6 \\
\hline Nymfeo & ISS & 070 & 13.0 & 12.5 & 0 & 10.8 & 56 & 60 & 260 & 0.48 & & & 6.2 \\
\hline Petron & ISS & 071 & 8.5 & 12.0 & 0 & 10.4 & 38 & 60 & 240 & 0.38 & & & 6.0 \\
\hline Chimaditis & ISS & 075 & 11.5 & 8.0 & 0 & 7.5 & 233 & 70 & 260 & 0.36 & & & 5.9 \\
\hline Ptolemaida & CSS & 072 & 25.3 & 13.9 & 0 & 11.5 & $15-50$ & $50-65$ & $250-270$ & 0.86 & $0.1-0.3$ & $\mathrm{n} / \mathrm{a}$ & 6.6 \\
\hline Vegoritida & ISS & 073 & 9.5 & 12.0 & 0 & 10.4 & 20 & 60 & 250 & 0.40 & & & 6.0 \\
\hline Vegora & ISS & 072 & 14.0 & 12.0 & 0 & 10.4 & 39 & 60 & 250 & 0.49 & & & 6.2 \\
\hline Perdika & ISS & 076 & 11.7 & 8.5 & 0 & 8.0 & 223 & 70 & 260 & 0.37 & & & 6.0 \\
\hline Komanos & CSS & 077 & 35.5 & 17.0 & 0 & 14.0 & $205-235$ & $45-80$ & $250-270$ & 1.16 & $0.1-0.3$ & $\mathrm{n} / \mathrm{a}$ & 6.8 \\
\hline Mesovouni & ISS & 077 & 18.0 & 12.0 & 0 & 10.9 & 211 & 65 & 255 & 0.48 & & & 6.3 \\
\hline Proastio & ISS & 078 & 11.0 & 11.0 & 0 & 10.0 & 223 & 65 & 265 & 0.35 & & & 6.1 \\
\hline Peraea & ISS & 074 & 13.8 & 9.5 & 0 & 8.9 & 27 & 70 & 250 & 0.43 & & & 6.1 \\
\hline Aliakmonas & CSS & 050 & 89.1 & 21.9 & 0 & 17.0 & $210-255$ & $40-80$ & $250-280$ & 1.34 & $0.3-0.5$ & $\mathrm{n} / \mathrm{a}$ & 6.9 \\
\hline Palaeochori & ISS & 050 & 21.0 & 18.0 & 0 & 14.7 & 246 & 55 & 255 & 0.65 & $0.3-0.3$ & 2.0 & 6.6 \\
\hline Rym nio & ISS & 051 & 13.0 & 16.5 & 0 & 13.5 & 231 & 55 & 275 & 0.48 & $0.3-0.3$ & 2.0 & 6.3 \\
\hline Servia & ISS & 052 & 16.9 & 15 & 0 & 13.0 & 228 & 60 & 280 & 0.52 & $1.0-2.0$ & $1.0-2.0$ & 6.4 \\
\hline Chromio & ISS & 053 & 10.0 & 6.5 & 1.5 & 6.5 & 91 & 50 & 280 & 0.22 & & & 5.8 \\
\hline Konitsa & CSS & 300 & 24.2 & 17.1 & 0 & 14.0 & $220-240$ & $45-75$ & $250-280$ & 0.86 & $0.1-0.4$ & $\mathrm{n} / \mathrm{a}$ & 6.6 \\
\hline Konitsa & ISS & 301 & 11.3 & 13.0 & 0 & 10.6 & 232 & 55 & 280 & 0.39 & & & 6.1 \\
\hline Petoussi & CSS & 310 & 39.1 & 16.1 & 0 & 16.0 & $80-260$ & $80-90$ & $315-355$ & 1.1 & $0.1-0.3$ & $\mathrm{n} / \mathrm{a}$ & 6.7 \\
\hline Souli & ISS & 310 & 14.6 & 12.0 & 0 & 12.0 & 82 & 85 & 330 & 0.51 & & & 6.3 \\
\hline Tomaros & ISS & 311 & 16.1 & 14.0 & 0 & 13.9 & 263 & 85 & 30 & 0.59 & & & 6.4 \\
\hline
\end{tabular}

Table 4. Seismotectonic parameters of the CSSs and ISSs included in the 'anti-Hellenides' fault system (see Figure 5). CSS, composite seismogenic source; ISS, individual seismogenic source; Code, identification number within the database; $\mathrm{n} / \mathrm{a}$, not available.

fault is possibly blind (Figure 5; Table 4). In any case, the event did not produce any observable ground rupture. The aftershock spatial distribution indicates a length of at least $14 \mathrm{~km}$, while analysis of the mainshock suggests a mean displacement of $0.34 \mathrm{~m}$. The focal mechanisms show a SE-dipping, NE-SW-trending, dip-slip normal fault [Dziewonski et al. 1991, Panagiotopoulos et al. 1993, Baker et al. 1997, Vannucci and Gasperini 2003, Vannucci and Gasperini 2004].

In the vicinity of the Goumenissa ISS, in October of 1395, there was the so-called Edhessa earthquake [Ambraseys 1999, 2009] (Table 1) that had a possible magnitude of 6.7
[Papazachos and Papazachou 1997] (see Table 1). However, the tentative location of the macroseismic epicenter is similarly close to the South Almopia CSS and not very far from the North Almopia CSS (see $\S 5.1$ ). Accordingly, the present stateof-knowledge does not allow the association of this strong earthquake with any recognized structure.

\subsection{South Almopia CSS}

The South Almopia CSS (CSS code, $\mathbf{0 6 8}$ ) is $20 \mathrm{~km}$ long and dips towards the south, showing a marked arcuate fault trace (Figure 5; Table 4). Information about the fault derives 
from morphotectonic investigations [Pavlides 1998], which document ENE-WSW-striking, dip-slip normal faults that affect the pyroclastic sediments that were deposited about 4.8 Ma ago. Mesostructural analysis of these deposits revealed a NNW-SSE direction of the $\sigma_{3}$ axis. The measured dip of the faults is high. The structure is considered active also due to its ideal orientation with respect to the regional stress field. On the assumption of complete reactivation of the whole fault zone, the maximum expected magnitude is 6.3 [based on the empirical relationship of Wells and Coppersmith 1994].

\subsection{Amyndeo CSS (Nymfeo and Petron ISSs)}

As mentioned above, the Ptolemaida Basin is a tectonically controlled area that is characterized by alternating subparallel ridges and basins, all of which are elongated in a NE-SW direction [Pavlides 1985] and associated with subparallel fault zones that are possibly linked at depth by a lowangle, SE-dipping shear zone (CSS code, 070) (Figure 5; Table 4). Several major fault zones that control large morphological structures, and smaller individual, but not less significant, fault zones, have been recognised and studied [Pavlides 1985, Pavlides and Mountrakis 1987, Doutsos and Koukouvelas 1998, Goldsworthy et al. 2002]. Field measurements of all of the active tectonic structures in the Ptolemaida Basin indicate a $(\mathrm{N}) \mathrm{NW}-(\mathrm{S}) \mathrm{SE}$ direction of the slip vector [Pavlides 1985, Pavlides and Mountrakis 1987, Doutsos and Koukouvelas 1998]. Although the morphotectonic features of the area indicate intensive and recent activity, there has been neither significant historical nor instrumental seismic activity recorded. A seismogenic layer thickness of ca. $13 \mathrm{~km}$ is inferred from seismotectonic considerations [Pavlides and Simeakis $1987 / 88]$.

The northernmost structure is the Amyndeo CSS showing clear geological and morphological evidence of recent activity [Pavlides 1985, Pavlides and Mountrakis 1987, Doutsos and Koukouvelas 1998, Goldsworthy et al. 2002]. The Amyndeo fault zone borders and tectonically controls the mountain front along a SW-trending ridge that separates the Ptolemaida Basin from the Florina Basin to the north, and that connects the two mountains of Voras, to the east, and Vernon, to the west. All along its almost $40 \mathrm{~km}$ of total length it has produced a discrete morphological slope as a result of a major dip-slip normal motion with a slight rightlateral strike-slip component, as documented by slickenlines [Pavlides 1985]. However, the fault zone is not entirely uniform. West of the village of Petron, the relief locally becomes subdued, while a slight change in the mountain front orientation can be seen. Accordingly, the fault zone is divided into two segments: the Petron (ISS code 071) and Nymfaeo (ISS code $\mathbf{0 7 0}$ ) ISSs, as NE and SW, respectively.

The Petron ISS is a ca. 9-km-long structure that controls the local depression where Lake Petron is located. The fault has shaped a linear and steep coastline on Mesozoic limestone, which is characterized by evident slickensides that show scree deposits and cataclastic breccias [Pavlides 1985]. The fault trace continues northeastwards for $2-3 \mathrm{~km}$, running along a small narrow valley. Towards the southwest, the fault cuts through Neogene sediments (upper Miocenelower Pliocene), while NNE-trending secondary structures also affect the Pleistocene deposits. The southwestern faulttip is covered by Pliocene-Pleistocene sediments, which suggests that the Petron-Nymfaeo segment boundary probably corresponds to a permanent barrier.

The Nymfaeo ISS is a larger (13 km long), NE-SWtrending structure that shows angular segment boundary geometry. Near to its northeastern tip, the fault shows and downthrows Pliocene sediments [Pavlides 1985]. Towards the $\mathrm{SW}$, a major escarpment possibly documents cumulative displacement of up to $700 \mathrm{~m}$ to $800 \mathrm{~m}$. The fault has also been detected by vertical electrical soundings and boreholes [Atzemoglou et al. 2003].

The Petron and Nymfaeo ISSs are capable of producing 6.0 and 6.2 earthquakes, respectively, with a mean coseismic displacement of $0.38 \mathrm{~m}$ and $0.48 \mathrm{~m}$, respectively. However, both ISSs could possibly extend further NE and SW, respectively (worst-case scenarios), and therefore the maximum expected magnitudes might be as high as 6.6 [based on the empirical relationship of Wells and Coppersmith 1994].

\subsection{Chimatidis ISS}

Parallel and antithetic to the Nymfaeo ISS, a 12-km-long active tectonic structure (ISS code, 075) lies along the southern shore of Lake Chimaditis (Figure 5; Table 4) [Pavlides 1985, Pavlides and Mountrakis 1987]. The NW-dipping, dipslip normal Chimaditis ISS has generated a low elongated terrace on its footwall, which consists of uplifted Neogene, Pleistocene and Holocene deposits [Pavlides 1985]. This structure probably joins the Nymfaeo ISS at depth, constraining its maximum depth to ca. $7.5 \mathrm{~km}$. Accordingly, the maximum expected magnitude is probably $<6.0$ [based on the empirical relationship of Wells and Coppersmith 1994].

\subsection{Ptolemaida CSS (Vegoritida and Vegora ISSs)}

Parallel to and synthetic with the central-northern sector of the Amyndeo CSS, there is the 25-km-long Ptolemaida CSS (CSS code, 072) (Figure 5; Table 4). This fault zone shows clear morphotectonic evidence of recent activity, and consists of two segments: the Vegoritida and Vegora ISSs, as $\mathrm{NE}$ and SW, respectively.

The ca. 10-km-long, (N)NE-trending Vegoritida ISS (ISS code, 073) shows an impressive morphology, with a high limestone cliff, and it borders on the homonymous lake. A minimum cumulative downthrow of $500 \mathrm{~m}$ is morphologically inferred [Pavlides 1985], while high-resolution Boomer profiles carried out in the lake suggested a vertical strati- 
graphic displacement of about $600 \mathrm{~m}$ to $700 \mathrm{~m}$ [Sakellariou et al. 2001]. Mesostructural analyses document a recent NNW-SSE trending direction of stretching [Pavlides 1985, Pavlides and Mountrakis 1987, Doutsos and Koukouvelas 1998, Mountrakis et al. 2006].

The Vegora ISS (ISS code, 072) continues for at least 12 $\mathrm{km}$ southwestwards, forming an arcuate escarpment [Pavlides 1985, Pavlides and Mountrakis 1987, Doutsos and Koukouvelas 1998]. The absence of limestone in the footwall of this fault results in a more subtle morphology. Nevertheless, a few scattered limestone scarps bear striations that indicate a roughly dip-slip normal kinematics associated with a NW-SE direction of extension [Pavlides 1985]. Neogene and Quaternary sediments are affected by the fault. The high-resolution Boomer profiles of the lake bottom suggest an offshore continuation of the fault [Sakellariou et al. 2001]. As a result, the fault overlaps the Vegoritida ISS, probably reaching a total length of more than $14 \mathrm{~km}$.

Each fault segment is capable of producing an earthquake of 6.0 and 6.2, with mean co-seismic displacements of $0.40 \mathrm{~m}$ and $0.49 \mathrm{~m}$ (Vegoritida and Vegora ISSs, respectively). However, a rupture of the entire fault zone is a possible (worst-case) scenario, given that the segment boundary does not appear to be strong enough to prevent this. In this case, the maximum estimated magnitude would be 6.6 [based on the empirical relationship of Wells and Coppersmith 1994].

\subsection{Perdika ISS}

The Perdika ISS (ISS code 076) is sub-parallel to and synthetic with the Chimatidis Fault (see $\S 5.5$ ), and lies $6 \mathrm{~km}$ to the south of it (Figure 5; Table 4) [Pavlides 1985, Pavlides and Mountrakis 1987, Goldsworthy et al. 2002, Mountrakis et al. 2006]. The Perdika ISS is a $12-\mathrm{km}$-long structure that borders the northern hillside of the Bordeaux Heights, which separate the Pliocene(?) sediments that outcrop in the footwall from the Quaternary deposits of the plain. From its similarity with the other structures of the broader Ptolemaida Basin, and according to the regional stress field, the kinematics of the Perdika Fault is basically dip-slip normal. A possible reactivation of the fault would produce an earthquake with a maximum expected magnitude of 6.0 [based on the empirical relationship of Wells and Coppersmith 1994].

\subsection{Komanos CSS (Mesovouni and Proastio ISSs)}

The (N)NE-(S)SW-trending and NW-dipping Komanos CSS (CSS code, 077) bounds the southeasternmost margin of the Ptolemaida Basin (Figure 5) [Pavlides 1985, Pavlides and Mountrakis 1987, Mountrakis et al. 2006]. Two major segments have been recognized: the Mesovouni and Proastio ISSs, as NE and SW, respectively [Mountrakis et al. 2006]. The fault zone has a total length of ca. $36 \mathrm{~km}$, although morphological evidence in the central sector is poor and introduces some uncertainty into the location of the segment boundary. Both segments have a steep NW-dip.

The Mesovouni ISS (ISS code, 077) runs along the northwestern front of Mount Vermion for at least $18 \mathrm{~km}$ [Pavlides 1985, Pavlides and Mountrakis 1987, Doutsos and Koukouvelas 1998, Mountrakis et al. 2006], showing a low mountainfront sinuosity index. Quaternary deposits have been mainly accumulated within a secondary accommodation structure (a 1.5-km-wide symmetric graben), which thus suggests the recent activity of this fault [Pavlides 1985, Pavlides and Mountrakis 1987, Mountrakis et al. 2006]. The measured cumulative displacements in Pliocene lignite deposits, deriving from borehole data, range from $20-40 \mathrm{~m}$ to up to $70 \mathrm{~m}$ [Pavlides 1985]. On July 9,1984 , a moderate earthquake $\left(M_{w}=5.2\right)$ occurred between the Mesovouni and Peraea ISSs (see §5.9; Pavlides and Simeakis 1987/88, Dziewonski et al. 1985, Anderson and Jackson 1987]. The obtained focal mechanisms [Dziewonski et al. 1985, Anderson and Jackson 1987] are in agreement with the local tectonic setting, and specifically with the seismotectonic features of the Mesovouni Fault.

The Proastio ISS (ISS code, 078) lies on the northern borders of the lignite mines [Pavlides 1985, Pavlides and Mountrakis 1987, Doutsos and Koukouvelas 1998, Mountrakis et al. 2006]. It is expressed by a group of parallel minor fault scarps of Quaternary sediments. Towards the northeast, borehole data show a down-stepping throw of the Pliocene lignite deposits, with a cumulative displacement of almost $300 \mathrm{~m}$ to $400 \mathrm{~m}$ [Pavlides 1985]. Secondary antithetic structures were also observed on the footwall, which form a minor tectonic horst [Pavlides 1985, Diamantopoulos 2006]. The fault zone extends for ca. $11 \mathrm{~km}$. Kinematic indicators document an almost pure dip-slip normal motion [Pavlides 1985, Pavlides and Mountrakis 1987] and a NW-SE direction of extension.

After using the empirical relationship of Wells and Coppersmith [1994], it appears that the individual rupture of each segment can produce events of 6.3 and 6.1 (maximum expected magnitudes; the Mesovouni and Proastio ISSs, respectively). Their corresponding co-seismic mean displacements are calculated to be $0.48 \mathrm{~m}$ and $0.35 \mathrm{~m}$. As the boundary between the two segments has not been clearly defined, and especially its nature (i.e. strong or soft boundary), the possible rupture of the entire fault zone cannot be excluded a priori. In this case (worst-case scenario), the maximum expected magnitude would be 6.8 .

\subsection{Peraea ISS}

The Peraea ISS (ISS code, 074) (Figure 5; Table 4) is an active structure close to, but antithetic with, the Komanos CSS (see §5.8) and at the same time synthetic to the Ptolemaida CSS (see §5.6) [Pavlides 1985, Pavlides and Mountrakis 1987, Goldsworthy and Jackson 2000, Goldsworthy and Jackson 2001, Mountrakis et al. 2006]. This SE-dipping fault is marked by a discontinuous escarpment that extends for a total length 
of ca. $14 \mathrm{~km}$. Well preserved slickensides and free faces put the Mesozoic substratum in contact with Holocene deposits [Pavlides 1985, Goldsworthy and Jackson 2000, Goldsworthy and Jackson 2001]. The estimated mean co-seismic displacement of the fault is $0.43 \mathrm{~m}$ and I would produce an earthquake of expected maximum magnitude 6.1.

\subsection{Aliakmonas CSS (Palaeochori, Rymnio, Servia and} Chromio ISSs)

The Aliakmonas fault zone (CSS code, 050) is a NE-SWtrending, NW-dipping major tectonic structure that controls a long stretch of the homonymous river (Figure 5; Table 4). The total length of this CSS is $89.1 \mathrm{~km}$. Geological and morphotectonic investigations suggest that there are three major segments: Palaeochori (ISS code, 050), Rymnio (ISS code, 051) and Servia (ISS code, 052) (from SW to NE) [Pavlides et al. 1995, Meyer et al. 1996, Chatzipetros 1998, Doutsos and Koukouvelas 1998, Meyer et al. 1998, Mountrakis et al. 1998]. The aftershock spatial distribution of an event that occurred in 1995 (see below: the Palaeochori ISS) [Hatzfeld et al. 1997, 1998] documents a maximum seismogenic depth of $15 \mathrm{~km}$, which possibly becomes gradually shallower from the southwestern to the north-eastern parts of the fault zone. Moreover, based on morphological evidence, Doutsos and Koukouvelas [1998] suggested a recent westward migration of the tectonic activity. The penultimate strong event in the area was reported by Stiros [1998] and Ambraseys [1999], and is dated at ca. 1700 (possibly 1695), based on historical data.

The Palaeochori ISS is marked by a ca. $21-\mathrm{km}$-long discontinuous escarpment that fades away towards the SW [Pavlides et al. 1995, Doutsos and Koukouvelas 1998, Mountrakis et al. 1998]. It was ruptured during the May 13, 1995, Kozani earthquake $\left(\mathrm{M}_{\mathrm{w}}=6.5\right.$; Table 1$)$, producing aligned, but not continuous, co-seismic ground ruptures all along its length [Pavlides et al. 1995, Mountrakis et al. 1998]. Based on nodal planes from focal mechanisms [Papazachos et al. 1998, Dziewonski et al. 1996, Kiratzi and Louvari 2003, Vannucci and Gasperini 2003, Vannucci and Gasperini 2004], earthquake tomographies from the aftershocks [Chiarabba and Selvaggi 1997], aftershock spatial distributions [Hatzfeld et al. 1997, 1998], stress tensor inversions [Kiratzi 1999], forward modeling of the source from strong-motion waveforms [Suhadolc et al. 2007], and InSAR images analyses [Meyer et al. 1996, Meyer et al. 1998, Rigo et al. 2004, Resor et al. 2005], it is possible to constrain several seismotectonic parameters. Based on paleoseismological investigations, a recurrence interval of $10 \mathrm{ka}$ to $30 \mathrm{ka}$ was tentatively suggested [Chatzipetros et al. 1998], which we now consider as likely to be an overestimation. During the 1995 seismic crisis, the spatiotemporal distribution of the aftershocks revealed a secondary antithetic structure, the Chromio ISS [Hatzfeld et al. 1997, 1998], which also produced S-dipping co-seismic ground ruptures aligned in an E-W direction [Pavlides et al. 1995, Moun- trakis et al. 1998]. The latter is considered as an inherited Sdipping, right-lateral, strike-slip fault that was reactivated in the new tectonic regime as a dip-slip, normal fault antithetic to the Palaeochori ISS [Pavlides et al. 1995, Hatzfeld et al. 1997, Hatzfeld et al. 1998, Mountrakis et al. 1998].

The Rymnio ISS lies northeast of the Palaeochori ISS, and it is separated from it by an angular barrier. The fault is marked by a distinct escarpment, especially in the northeastern sector [Pavlides et al. 1995, Doutsos and Koukouvelas 1998, Mountrakis et al. 1998]. Also, the northeastern boundary of the Rymnio segment corresponds to a strong geometric barrier (right-stepping, underlapping geometry) [Pavlides et al. 1995, Meyer et al. 1996, Doutsos and Koukouvelas 1998, Meyer et al. 1998, Mountrakis et al. 1998]. The total length is ca. $13 \mathrm{~km}$. A partial rupture of this structure was claimed to have occurred in the 1995 earthquake, based on some ground ruptures observed near to the village of Rymnio. However, their occurrence along the lakeshore probably indicates gravitational phenomena. Morphotectonic investigations [Pavlides et al. 1995, Meyer et al. 1996, Doutsos and Koukouvelas 1998, Meyer et al. 1998, Mountrakis et al. 1998] indicate similar geometry and kinematics to the nearby tectonic structures.

Next to the Rymnio Fault there is the Servia ISS, which represents the most prominent neotectonic structure of the Aliakmonas CSS. This fault is documented by a long, well polished sliding surface on limestone, which bears a set of fresh striations, documenting a (N)NW-(S)SE direction of extension [Pavlides et al. 1995, Meyer et al. 1996, Meyer et al. 1998, Mountrakis et al. 1998, Goldsworthy and Jackson 2000]. There was no sign of reactivation during the 1995 earthquake. The northeastern tip of the fault is not well defined. Based on the asymmetric shape of the along-strike displacement profile, Doutsos and Koukouvelas [1998] suggested a possible linking of the Servia and Rymnio ISSs. A slip per event of $0.5 \mathrm{~m}$ was calculated from empirical relationships, while based on geomorphic markers, a slip rate of $1 \mathrm{~mm} / \mathrm{a}$ to $2 \mathrm{~mm} / \mathrm{a}$, and a mean recurrence interval of $1 \mathrm{ka}$ to $2 \mathrm{ka}$ have been suggested [Meyer et al. 1996]. A maximum cumulative displacement across the fault of $2100 \mathrm{~m}$ was proposed by Doutsos and Koukouvelas [1998]. On September 26, 1695, an earthquake $\left(\mathrm{M}_{\mathrm{e}}=6.5\right)$ struck the area, with the macroseismic epicenter tentatively located in the hanging-wall of the Rymnio Fault [Papazachos and Papazachou 1997, Ambraseys 1999, Ambraseys 2009]. However, the lack of details prevents any straightforward correlation with any specific segment of the Aliakmonas CSS.

It is of note that the Aliakmonas CSS continues northeastwards following the valley separating Mount Vermion from the Pieria Mountain chain. For this sector, a fourth distinct $25-\mathrm{km}$-long fault segment has been tentatively suggested [referred to as Polyphytos-Polydendri, by Mountrakis et al. 2006], which however does not show definite evidence 
of recent seismogenic activity. Accordingly, we have included this structure in the CSS without defining a specific ISS in the GreDaSS.

\subsection{Konitsa CSS and ISS}

The Konitsa CSS (CSS code, 300) is a ca. 25-km-long, NW-dipping structure that borders the mountain front of Mount Tymfi (Figure 5; Table 4). The best evidence of recent activity is limited to a length of $11 \mathrm{~km}$ along the southern margin of the elongated Aoos Basin, which corresponds to the Konitsa ISS. In particular, based on several morphotectonic and structural investigations [Doutsos and Koukouvelas 1998, Doutsos and Kokkalas 2001, Goldsworthy et al. 2002, Galanakis et al. 2007], the fault has been associated with a major escarpment that is delimited by a linear mountain front. Observations include many fresh slickensides on the Mesozoic limestone, which also bear corrugations, and which are usually delimiting for the Miocene flysch, and sometimes also for Quaternary deposits. Although Goldsworthy et al. [2002] suggested the possible northeastern continuation of this structure and its connection with the fault system of the Ptolemaida Basin, the Konitsa CSS is mechanically bounded by a roughly perpendicular Neogene thrust that causes displacement to decrease rapidly eastwards [Doutsos and Koukouvelas 1998].

On July 26, 1996, a moderate earthquake $\left(\mathrm{M}_{\mathrm{s}}=5.4\right.$, according to Papanastassiou [2001]; or $\mathrm{M}_{\mathrm{w}}=5.1$, according to EMMA catalogue; Vannucci and Gasperini 2003, 2004] occurred near the town of Konitsa. A couple of weeks later, another moderate, but stronger, event $\left(\mathrm{M}_{\mathrm{s}}=5.7\right.$, according to Papanastassiou [2001]; or $\mathrm{M}_{\mathrm{w}}=5.3$, according to Dziewonski et al. [1997]) occurred in the same seismogenic volume. The observed co-seismic ruptures [Galanakis et al. 2007] and the computed focal mechanisms [Dziewonski et al. 1997, Vannucci and Gasperini 2003, Vannucci and Gasperini 2004] are in agreement with mesostructural analyses that show a normal dip-slip motion in a NW-extensional field [Doutsos and Koukouvelas 1998, Doutsos and Kokkalas 2001, Galanakis et al. 2007]. An average dip of $55^{\circ}$ and a maximum depth of ca. 11 $\mathrm{km}$ have been inferred from the aftershock spatial distribution, which also suggested a listric shape at depth [Papanastassiou 2001]. Although the largest magnitude that was instrumentally recorded during the 1996 sequence was the $\mathrm{M}_{\mathrm{w}}=5.3$ event, the expected maximum magnitude for the Konitsa ISS (ISS code 301) is 6.1, with a mean coseismic displacement of ca. $0.4 \mathrm{~m}$. Moreover, if we take into account the total length of the CSS, then the maximum expected magnitude could be as high as 6.6 [based on the empirical relationship of Wells and Coppersmith 1994].

\subsection{Petoussi CSS (Souli and Tomaros ISSs)}

The Petoussi CSS (CSS code, 310) is a ca. 39-km-long fault zone that is mainly inherited from the Mesozoic evolution and the Alpine tectonics (Figure 5; Table 4) [Caputo and
Zouros 1993, Boccaletti et al. 1997]. Although the Petoussi CSS has a different strike (E-W) with respect to the other seismogenic sources included in the Western MacedoniaEpirus fault system, a regional-scale undulation of the orogene also makes this fault zone a typical anti-Hellenic structure. The Petoussi CSS is a sub-vertical fault zone with local changes in dip direction, having kinematic indicators that document a prominent left-lateral, strike-slip motion [Caputo and Zouros 1993]. This geological setting has formed positive and negative flower structures, as well as secondary splay faults [Boccaletti et al. 1997]. Based on these differences, we divided the fault zone into two major segments: the Tomaros (ISS code 311) and Souli (ISS code 310) ISSs, as east and west, respectively. The recent activity of the Petoussi CSS is based on morphotectonic investigations and paleoseismological trenches, which document at least three paleoevents during the last ca. $30 \mathrm{ka}$ BP along the Souli Fault [Boccaletti et al. 1997], therefore suggesting a recurrence interval of several thousand years.

Microearthquake surveys document an eastwards increase in the seismogenic depth from $<12 \mathrm{~km}$ to $>15 \mathrm{~km}$, and both strike-slip and normal dip-slip focal mechanisms [King et al. 1983, Hatzfeld et al. 1995, Tselentis et al. 2006]. The calculated mean displacements for the Souli and Tomaros ISSs are $0.51 \mathrm{~m}$ and $0.59 \mathrm{~m}$, respectively, while the maximum expected magnitudes [based on the empirical relationship of Wells and Coppersmith 1994] are 6.3 and 6.4, respectively. The worst-case scenario would be an earthquake that ruptures the whole length of the Petoussi CSS, and in this case, on the basis of the same scaling laws, the maximum expected magnitude would be 6.7 .

\section{The North Aegean Sea fault system}

A strong limitation in investigations into offshore faults is the complete lack of direct observations in terms of morphotectonic and geological approaches, which is partly compensated for by the very detailed bathymetric maps that are available [e.g. Maley and Johnson 1971, IOC 1981, Papanikolaou et al. 2002] and seismic reflection investigations that have been carried out [e.g. Brooks and Ferentinos 1980, Mascle and Martin 1990, Roussos and Lyssimachou 1991, Papanikolaou et al. 2006]. Accordingly, most of the information concerning offshore faults is provided by seismic data, like focal mechanisms and microseismic distributions [e.g. Dziewonski et al. 1983, Dziewonski et al. 1984, Rocca et al. 1985, Kiratzi 1991, Taymaz et al. 1991].

The North Aegean Sea is dominated by two regionalscale tectonic structures: the North Aegean Basin and the North Aegean Trough, which are directly connected and represent the western continuation of the North Anatolian Fault (Figure 6; Table 5). The North Aegean Basin is situated between the Chalkidiki peninsula, the Thessalian coast and the Sporades Islands. Along strike, it is bordered by two major 


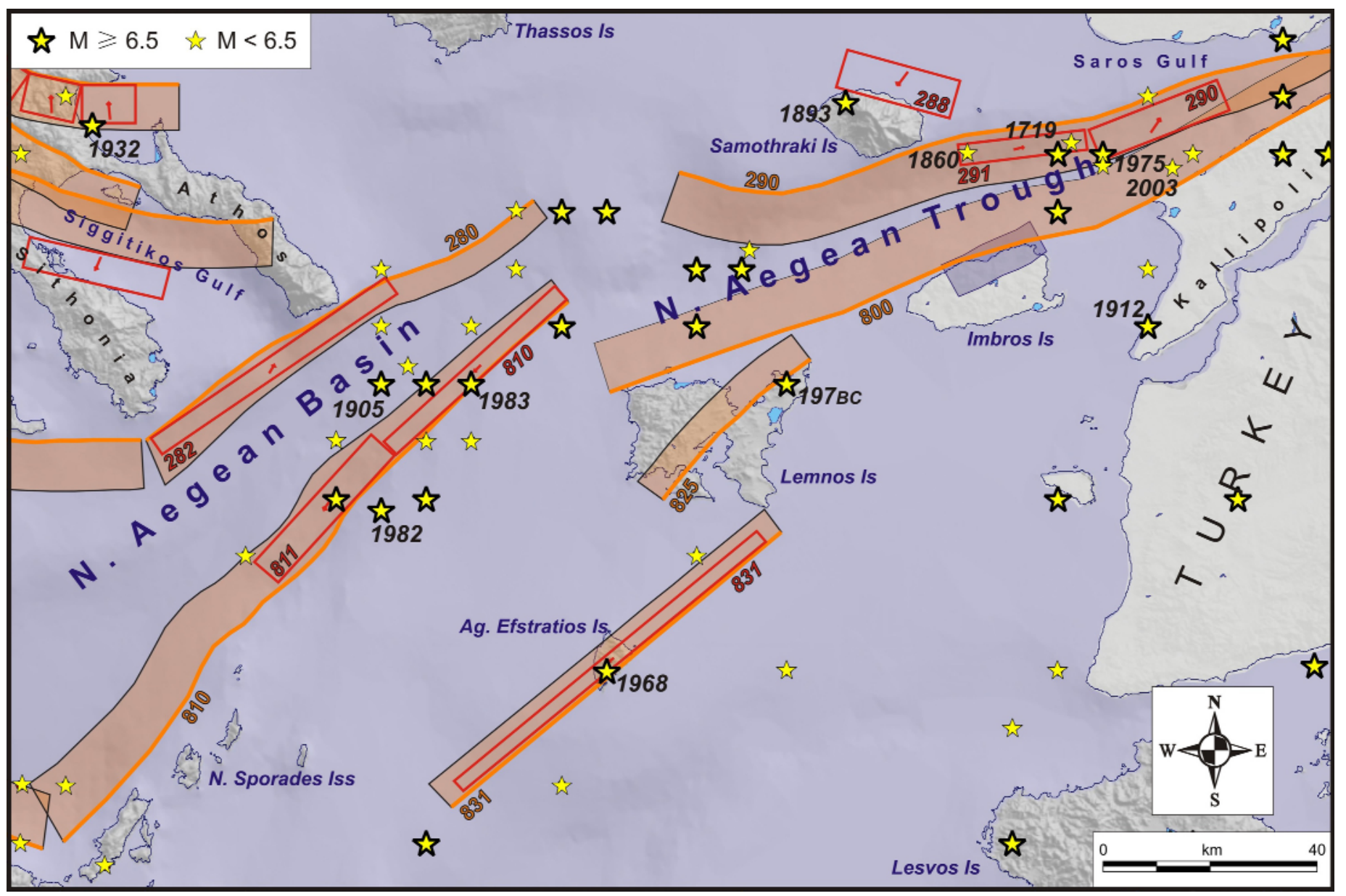

Figure 6. Map detail of the seismogenic sources belonging to the "North Aegean Sea fault system". See Figure 1 for map location and seismogenic sources. Three-digit labels refer to the database code of the seismogenic source (ISS codes in italics). Years are provided for major earthquakes discussed in main the text (see also Table 1).

fault zones, which are mainly characterized by oblique-slip kinematics: the South Chalkidiki offshore and North Aegean Basin CSSs. Minor structures affect the interposed region, but the lack of sufficient data, their likely reduced dimensions (hence limited maximum expected magnitude), and their location far offshore from the Greek coastlines make their recognition more problematic at present, and their precise seismotectonic definition less urgent. For these reasons they are not included in this report.

The other regional-scale tectonic structure, the North Aegean Trough, is represented by a crustal-scale negative flower structure that affects the sea floor between Kallipoli (Gelibolu) peninsula and Lemnos and Imbros islands to the south, and Samothraki Island to the north. In this transtensional shear zone, two CSSs have been recognized (the north North Aegean Trough, and the south North Aegean Trough), which mark the mechanical-stress transition from the purely transcurrent tectonic regime of the North Anatolian Fault to the east, and the prevailingly extensional regime towards the west (the North Aegean Basin) [Pavlides et al. 1990, Taymaz et al. 1991, Pavlides and Caputo 1994, Papanikolaou et al. 2006]. Due to this lateral variation, the North Aegean Basin progressively widens and deepens westwards $[\mathrm{Pa}$ panikolaou et al. 2002]. For the purposes of this report, we focus only on the offshore part that lies west of the Kallipoli peninsula.

In the North Aegean region, there are other active tectonic structures that are synthetic or kinematically associated with those of the North Aegean Basin and North Aegean Trough: the Aghios Efstratios and Lemnos CSSs, and the Samothraki ISS.

\subsection{South Chalkidiki offshore CSS (Athos ISS)}

The South Chalkidiki offshore CSS (CSS code, 280) represents the northern boundary of the North Aegean Basin (Figure 6; Table 5). Its trace runs immediately south of the Sithonia and Athos peninsulae, forming a NE-SW-trending, steep submarine slope for a total length of ca. $90 \mathrm{~km}$, as has been documented by bathymetric surveys [Maley and Johnson 1971, Papanikolaou et al. 2002] and seismic profiles [Ferentinos et al. 1981, Roussos and Lyssimachou 1991, Papanikolaou et al. 2006]. Based on slight strike variations, and especially on the occurrence of a large earthquake that was probably associated with this fault zone, we define the Athos ISS (ISS code, 282). This earthquake occurred on November 8, 1905 (Table 1), and the macroseismic magnitude was 7.5 [Papazachos and Papazachou 1997] or 7.3 [Ambraseys 2001]. This fault segment is ca. $54 \mathrm{~km}$ long [Pa- 


\begin{tabular}{|c|c|c|c|c|c|c|c|c|c|c|c|c|c|}
\hline $\begin{array}{l}\text { Seismogenic } \\
\text { source }\end{array}$ & Type & Code & $\begin{array}{l}\text { Length } \\
(\mathrm{km})\end{array}$ & $\begin{array}{l}\text { Width } \\
(\mathrm{km})\end{array}$ & $\begin{array}{l}\text { Min. } \\
\text { depth } \\
(\mathrm{km})\end{array}$ & $\begin{array}{l}\text { Max. } \\
\text { depth } \\
(\mathrm{km})\end{array}$ & $\begin{array}{l}\text { Strike } \\
\left({ }^{\circ}\right)\end{array}$ & $\begin{array}{l}\text { Dip } \\
\left({ }^{\circ}\right)\end{array}$ & $\begin{array}{l}\text { Rake } \\
\left({ }^{\circ}\right)\end{array}$ & $\begin{array}{c}\text { Slip per } \\
\text { event } \\
(\mathrm{m})\end{array}$ & $\begin{array}{c}\text { Slip } \\
\text { rate } \\
(\mathrm{mm} / \mathrm{a})\end{array}$ & $\begin{array}{c}\text { Recurrence } \\
\text { interval } \\
\text { (ka) }\end{array}$ & $\begin{array}{c}\text { Potential } \\
\mathrm{M}_{\mathrm{w}}\end{array}$ \\
\hline $\begin{array}{c}\text { South Chalkidiki } \\
\text { offshore }\end{array}$ & CSS & 280 & 87.4 & 17.9 & 0 & 17.0 & $50-115$ & $65-85$ & $210-245$ & 2.1 & $1.0-1.7$ & $\mathrm{n} / \mathrm{a}$ & 7.2 \\
\hline Athos & ISS & 282 & 54.0 & 17.0 & 0 & 16.6 & 55 & 77 & 205 & 1.23 & & & 7.0 \\
\hline NAB & CSS & 810 & 143 & 18.3 & 0 & 17.0 & $200-240$ & $60-85$ & $170-190$ & 3.88 & $1.0-2.5$ & $\mathrm{n} / \mathrm{a}$ & 7.6 \\
\hline NAB segment A & ISS & 810 & 44.0 & 18.0 & 0 & 17.7 & 227 & 79 & 180 & 0.88 & & & 6.9 \\
\hline NAB segment $B$ & ISS & 811 & 33.0 & 17.5 & 0 & 16.4 & 222 & 70 & 188 & 0.97 & & & 6.8 \\
\hline South NAT & CSS & 800 & 275 & 18.9 & 0 & 18.0 & $235-275$ & $65-90$ & $190-225$ & 3.37 & $1.0-3.5$ & $\mathrm{n} / \mathrm{a}$ & 7.5 \\
\hline North NAT & CSS & 290 & 127 & 19.4 & 0 & 18.0 & $60-110$ & $60-90$ & $180-225$ & 1.92 & $2.0-3.2$ & $\mathrm{n} / \mathrm{a}$ & 7.1 \\
\hline Saros & ISS & 290 & 26 & 15.0 & 0 & 13.6 & 68 & 65 & 215 & 0.78 & & & 6.6 \\
\hline Samothraki SE & ISS & 291 & 24.0 & 15.0 & 0 & 14.5 & 83 & 75 & 185 & 0.75 & & & 6.6 \\
\hline North Samothraki & ISS & 288 & 22.0 & 15.0 & 0 & 13.0 & 286 & 60 & 250 & 0.60 & & & 6.5 \\
\hline Lemnos & CSS & 825 & 39.2 & 16.3 & 0 & 16.0 & $210-235$ & $75-90$ & $180-215$ & 1.26 & $0.8-2.7$ & $\mathrm{n} / \mathrm{a}$ & 6.8 \\
\hline Aghios Efstratios & CSS & 831 & 82.3 & 15.5 & 0 & 15.0 & $205-230$ & $70-90$ & $173-183$ & 2.21 & $0.8-1.6$ & $\mathrm{n} / \mathrm{a}$ & 7.2 \\
\hline Aghios Efstratios & ISS & 831 & 75.0 & 15.0 & 0 & 14.8 & 230 & 80 & 180 & 1.8 & & & 7.1 \\
\hline
\end{tabular}

Table 5. Seismotectonic parameters of the CSSs and ISSs included in the North Aegean Sea fault system (see Figure 6). CSS, composite seismogenic source; ISS, individual seismogenic source; Code, identification number within the database; n/a, not available; NAB, North Aegean Basin; NAT, North Aegean Trough.

panikolaou et al. 2006]. The maximum expected magnitude for the whole CSS is between 7.0 and possibly 7.5 , as the worst-case scenario [7.2 according to the empirical relationship of Wells and Coppersmith 1994].

\subsection{North Aegean Basin CSS (Segment A and Segment B)}

The North Aegean Basin CSS (CSS code 810) is one of the longest structures of the region, with a length of ca. $140 \mathrm{~km}$ (Figure 6; Table 5). It strikes NE-SW and represents the southern boundary of the North Aegean Basin, running from north of Lemnos to the Sporades Islands. The fault zone is well expressed morphologically, as it has formed a deep and steep NW-dipping slope, which is clearly imaged on detailed bathymetric maps [Maley and Johnson 1971, IOC 1981, Papanikolaou et al. 2002]. The cumulative downthrow of the sea-bottom is ca. $1300 \mathrm{~m}$. The fault zone is also clearly imaged in seismic reflection profiles, which indicates significant cumulative displacement and especially the deformation of the sea-bottom sediments [Brooks and Ferentinos 1980, Ferentinos et al. 1981, Mascle and Martin 1990, Roussos and Lyssimachou 1991, Papanikolaou et al. 2006]. There have been two well-documented strong earthquakes along this zone that were probably produced by two adjacent fault segments. Accordingly, we distinguish here two ISSs: Segment A (ISS code, 810) and Segment B (ISS code, 811), as east and west, respectively).

Segment A ISS was responsible for the August 6, 1983 $\left(\mathrm{M}_{\mathrm{w}}=6.7\right.$; Table 1), earthquake that reactivated the northeastern portion of the North Aegean Basin CSS. Based on the aftershock spatial distribution [Rocca et al. 1985, Taymaz et al. 1991] and the magnitude of the mainshock, a length of $44 \mathrm{~km}$ was inferred. Segment $B$ ISS is associated with the January $18,1982\left(\mathrm{M}_{\mathrm{w}}=6.6\right.$; Table 1), earthquake. Again, the length of $33 \mathrm{~km}$ is inferred from the aftershock spatial distribution [Taymaz et al. 1991] and the magnitude of the mainshock. There are many other focal mechanisms calculated for both of these 1982 and 1983 seismic crises [Dziewonski et al. 1984, Papazachos et al. 1984, Rocca et al. 1985, Ekström et al. 1987, Ekström and England 1989, Kiratzi et al. 1991, Taymaz et al. 1991, Jackson et al. 1992, Vannucci and Gasperini 2003, Vannucci and Gasperini 2004], all of which suggest very steep (NW-dipping) to sub-vertical nodal planes, and an almost pure right-lateral, strike-slip kinematics. The proposed segmentation is in agreement with the seismogenic source segments proposed by Papanikolaou and Papanikolaou [2007]. The calculated mean displacements of the two segments are $0.88 \mathrm{~m}$ and $0.97 \mathrm{~m}$ (Segment $A$ and Segment B, respectively). The 1982 and 1983 events probably represent the maximum expected magnitudes for these two segments, while in the case of a combined rupture (the worst-case scenario), the suggested maximum expected magnitude is 7.6 [Papanikolaou and Papanikolaou 2007].

\subsection{South North Aegean Trough CSS}

The south North Aegean Trough CSS (CSS code, 800) is probably the longest active structure in the Aegean Sea (Figure 6). It is oriented ENE-WSW, and runs north of Lemnos and Imbros Islands, and controls the Saros Gulf [Armijo et al. 
1999, Kiratzi 1991, Koral et al. 2009, Koukouvelas and Aydin 2002, Lybéris 1984, McNeill et al. 2004, Mercier et al. 1989, Papadimitriou and Sykes 2001, Saatçilar et al. 1999, Stanley and Perissoratis 1977]. Although the structure is likely to be in mechanical continuity with the fault segment of the North Anatolian Fault that ruptured the Kallipoli peninsula (August 9, 1912, $M_{w}=7.4$ ) in crossing it from the Saros Gulf to the Marmara Sea [Ambraseys and Finkel 1987, Altunel et al. 2004, Ambraseys 2002, Janssen et al. 2009, Kaya et al. 2004, Rockwell et al. 2001, Tüysüz et al. 1998, Yaltirak and Alpar 2002, Yaltirak et al. 1998], we will not discuss its continuation further eastwards in the framework of this report. The fault zone geometry is relatively well constrained, based on bathymetric data, seismic reflection profiles, microseismicity distribution, and focal mechanisms of moderate and strong events [Maley and Johnson 1971, Mascle and Martin 1990, Çagatay et al. 1998, Coskun 2000, Kurt et al. 2000, Ustaömer et al. 2008, Papazachos et al. 1991, Kiratzi et al. 1991, McNeill et al. 2004, Saatçilar et al. 1999, Taymaz et al. 1991, Karabulut et al. 2006]. Focal mechanisms document a prevailing strike-slip motion with a dip-slip component, while the distribution of the microseismicity suggests a steep (to sub-vertical) fault plane. The total length of the fault zone is probably more than $200 \mathrm{~km}$. Based on the overall geometry, there are certainly several segments, but the lack of specific data does not allow the segment boundaries, and especially their nature, to be determined. Accordingly, the maximum expected magnitude could range from 6.5 to probably more then 7.5, with a slip per event that possibly exceeds $3 \mathrm{~m}$.

\subsection{North North Aegean Trough CSS (Saros and Samothraki} SE ISSs)

Mechanically associated with the south North Aegean Trough CSS (see $\S$ 6.3), the north North Aegean Trough CSS (CSS code 290) runs subparallel and antithetic (SSE-dipping) to the former (Figure 6; Table 5). The two fault zones progressively converge eastwards, and they probably merge into a unique crustal-scale flower structure at the entrance of the Saros Gulf [Çagatay et al. 1998, Coskun 2000, Kurt et al. 2000, Yaltirak and Alpar 2002, Yaltirak et al. 1998]. The total length is more than $120 \mathrm{~km}$ and its kinematics is oblique-slip (to strike-slip), according to available focal mechanisms of moderate to large earthquakes. Based on the slightly articulated geometry, at least two segments have been recognized and included in the GreDaSS: the 26-km-long Saros ISS (ISS code 290), and the 24-km-long Samothraki SE ISS (ISS code 291). These faults ruptured for $M_{w}=6.6$ and $M_{w}=5.7$ earthquakes (Table 1), which occurred on March 27, 1975, and July 6, 2003, respectively, north of the Kallipoli peninsula and east of Samothraki Island [Kiratzi et al. 1985, Taymaz et al. 1991, Papazachos et al. 1991, Jackson et al. 1992, Papazachos and Papazachou 1997, Vannucci and Gasperini 2003, Vannucci and Gasperini 2004, Karabulut et al. 2006]. The focal mech- anisms suggest an oblique-slip motion (normal and dextral components) on a moderately SE-dipping fault plane for the Saros ISS [Kiratzi et al. 1985, Taymaz et al. 1991, Papazachos et al. 1991, Jackson et al. 1992], and an almost pure dextral strike-slip motion on a steeply SE-dipping fault plane for the Samothraki SE ISS [Karabulut et al. 2006]. An investigation of the 2003 sequence indicated a thick seismogenic layer of ca. $18 \mathrm{~km}$ [Karabulut et al. 2006]. Two historical large earthquakes have also been reported in this area [Papazchos and Papazachou 1997] (Table 1): the first on July 23, $1719\left(\mathrm{M}_{\mathrm{e}}=\right.$ 6.7), and the second on August 6, $1860\left(\mathrm{M}_{\mathrm{e}}=6.2\right)$. Although both of these events have not been accurately located, at least one could be related to the Samothraki SE fault segment. A tentative maximum expected magnitude is probably between 6.6 and 7.1 [based on the empirical relationship of Wells and Coppersmith 1994].

\subsection{North Samothraki ISS}

This fault (ISS code, 288) crosses the northern coast of Samothraki Island and continues on both sides offshore (Figure 6; Table 5). From a mechanical point of view, this fault can be interpreted as a normal dip-slip secondary structure of the North Aegean Trough. According to morphotectonic investigations, the fault is characterized by discrete scarps, most of which are aligned in an ESE-WNW direction and dip northwards [Pavlides et al. 2005]. They form a steep morphology that controls the drainage pattern and causes deposition of massive colluvial and alluvial deposits. The Samothraki ISS is probably the causative structure for the homonymous earthquake that occurred on February 9, 1893 [Papazachos and Papazachou 1997, 2003, Ambraseys 2009] (Table 1). Based on the estimated macroseismic magnitude of 6.8 [Papazachos and Papazachou 1997, 2003], the proposed length is at least $22 \mathrm{~km}$ [based on the empirical relationship of Wells and Coppersmith 1994].

\subsection{Lemnos CSS}

Lemnos CSS (CSS code, 825) is a ca. 40-km-long, NE-SWstriking, sub-vertical- strike-slip, right-lateral structure that runs across the homonymous island (Figure 6; Table 5) [Koukouvelas and Aydin 2002, Pavlides et al. 2009]. It consists of several smaller segments, some of which control the coastline of the northeastern part of the island. The location, geometry and kinematics of this structure imply a possible connection with the south North Aegean Trough CSS to the north. Even though the regional instrumental seismicity is rather low, a strong $\left(\mathrm{M}_{\mathrm{e}}=7.0\right)$ historical $(197 \mathrm{BC})$ earthquake is reported in the catalogue of Papazachos and Papazachou [1997] (Table 1), based on scripts of Pausanias, who refer to the sinking of Chryse Island, northeast of Lemnos. According to empirical relationships [Wells and Coppersmith 1994], the maximum expected magnitude of a total rupture of this fault zone is estimated at 6.8 . 


\subsection{Aghios Efstratios CSS and ISS}

The Aghios Efstratios CSS (CSS code, 831) is a NE-SWstriking, tectonic structure that runs south of Lemnos Island and crosses the small Aghios Efstratios Island (Figure 6; Table $5)$. Although it is parallel to the North Aegean Basin CSS (see $\S 6.2$ ), its motion is mainly transcurrent as it derives from the available focal mechanism of the 1968 event that ruptured most of the structure [McKenzie 1972, Kiratzi et al. 1991, Taymaz et al. 1991, Vannucci and Gasperini 2003, Vannucci and Gasperini 2004] (Table 1). Field mapping indicates a NWdipping, steep to sub-vertical fault with significant right-lateral motion [Pavlides et al. 1990, Pavlides and Tranos 1991]. The source dimensions (length, $75 \mathrm{~km}$; width, $15 \mathrm{~km}$ ) and an average displacement of $1.8 \mathrm{~m}$ were scaled on the magnitude of the $M_{s}=7.11968$ earthquake [North 1977]. These values are in good agreement with the aftershock spatial distribution [Drakopoulos and Economides 1972], although more recent studies [Nalbant et al. 1998, Papadimitriou and Sykes 2001] suggest different dimensions and displacement [see discussion in Pavlides et al. 2009].

\section{The Thessalian fault system}

The first-order topographic texture of Thessaly is characterized by a NW-SE-trending, basin-and-range-like tectonic system of latest Miocene-Early Pleistocene age, in the region between the Pindos Mountain chain to the west, and the Aegean Sea to the east (Figure 7; Table 6). However, since the Middle Pleistocene, the area has been in a N(NE)-
S(SW) extensional regime that created mainly normal E-Wtrending fault systems, generally overprinting the older basins, but locally exploiting inherited structures [Caputo and Pavlides 1993]. As a consequence, the mean direction of the active faults is (E)SE-(W)NW. On land, structures are concentrated to the northern Larissa plain, where they form the Tyrnavos Basin-Gonnoi Horst (the South Tyrnavos Basin, Tyrnavos, North Tyrnavos Basin and Omolio CSSs), and in southern Thessaly (the Pagasitikos, Vasilika and Domokos CSSs), which generates an almost continuous belt from the Pagasitikos Gulf to the east, to the Karditsa plain to the west [Caputo 1995]. There is an important differentiation though, between the northern and southern sectors. Indeed, southern Thessaly has been struck by several strong earthquakes during historical as well as instrumental recording period [Papadopoulos 1992] (Table 1), while in northern Thessaly, there have been no strong events during the last 2-3 centuries, with the only exception of the 1941 Larissa earthquake [Caputo and Helly 2005a]. Nevertheless, geological, palaeoseismological and morphotectonic investigations clearly document strong linear morphogenic events also in the Tyrnavos Basin [Caputo et al. 1994, 2003, 2004a]. Based on this difference, a seismic gap in northern Thessaly has been suggested [Caputo 1995].

Three more CSSs belong to this geodynamic sector, which thus extends eastwards offshore from the Thessalian coast (the South Cassandra offshore, Mavrovouni offshore and Pelion offshore CSSs). These seismogenic sources are grouped

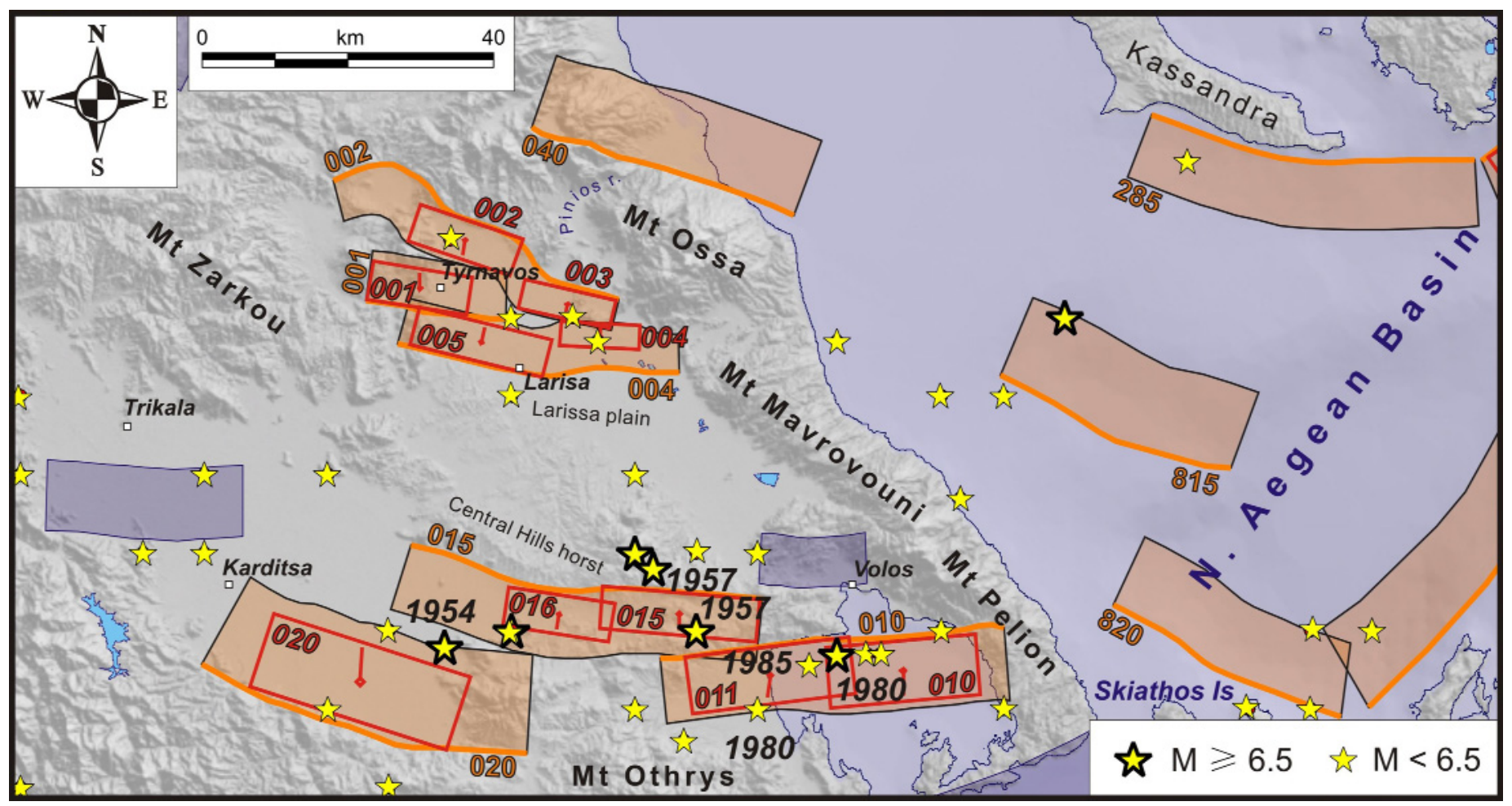

Figure 7. Map detail of the seismogenic sources belonging to the "Thessalian fault system". See Figure 1 for map location and seismogenic sources. Three-digit labels refer to the database code of the seismogenic source (ISS codes in italics). Years are provided for major earthquakes discussed in the main text (see also Table 1). 


\begin{tabular}{|c|c|c|c|c|c|c|c|c|c|c|c|c|c|}
\hline $\begin{array}{l}\text { Seismogenic } \\
\text { source }\end{array}$ & Type & Code & $\begin{array}{l}\text { Length } \\
(\mathrm{km})\end{array}$ & $\begin{array}{l}\text { Width } \\
(\mathrm{km})\end{array}$ & $\begin{array}{l}\text { Min. } \\
\text { depth } \\
(\mathrm{km})\end{array}$ & $\begin{array}{l}\text { Max. } \\
\text { depth } \\
(\mathrm{km})\end{array}$ & $\begin{array}{l}\text { Strike } \\
\left({ }^{\circ}\right)\end{array}$ & $\begin{array}{l}\text { Dip } \\
\left({ }^{\circ}\right)\end{array}$ & $\begin{array}{l}\text { Rake } \\
\left({ }^{\circ}\right)\end{array}$ & $\begin{array}{c}\text { Slip per } \\
\text { event } \\
(\mathrm{m})\end{array}$ & $\begin{array}{c}\text { Slip } \\
\text { rate } \\
(\mathrm{mm} / \mathrm{a})\end{array}$ & $\begin{array}{c}\text { Recurrence } \\
\text { interval } \\
\text { (ka) }\end{array}$ & $\begin{array}{c}\text { Potential } \\
\mathrm{M}_{\mathrm{w}}\end{array}$ \\
\hline Pagasitikos Gulf & CSS & 010 & 48.5 & 16.4 & 0 & 12.5 & 58-104 & $40-70$ & $232-270$ & 1.56 & $0.5-3.0$ & $\mathrm{n} / \mathrm{a}$ & 7.0 \\
\hline Volos & ISS & 010 & 21.0 & 15.0 & 0 & 12.3 & 85 & 55 & 266 & 0.63 & $1.0-3.0$ & & 6.5 \\
\hline Nea Anchialos & ISS & 011 & 23.0 & 14.0 & 0 & 11.5 & 83 & 55 & 255 & 0.18 & $1.0-3.0$ & 1.5 & 6.1 \\
\hline Vasilika & CSS & 015 & 50.3 & 18.0 & 0 & 14.5 & $80-115$ & $45-70$ & $260-280$ & 1.56 & $0.6-0.9$ & $\mathrm{n} / \mathrm{a}$ & 7.0 \\
\hline Righeo & ISS & 015 & 22.0 & 14.0 & 0 & 12.7 & 95 & 65 & 275 & 0.8 & & & 6.5 \\
\hline Dasolofos & ISS & 016 & 15.3 & 13.0 & 0 & 11.8 & 99 & 65 & 270 & 0.6 & & & 6.3 \\
\hline Domokos & CSS & 020 & 48.1 & 23.7 & 0 & 17.5 & $270-300$ & $40-60$ & $270-280$ & 1.56 & $0.3-0.6$ & $\mathrm{n} / \mathrm{a}$ & 7.0 \\
\hline Ekkara & ISS & 020 & 29.0 & 17.0 & 0 & 13.0 & 288 & 50 & 285 & 0.75 & $0.3-0.5$ & 3.2 & 6.7 \\
\hline $\begin{array}{c}\text { South Tyrnavos } \\
\text { Basin }\end{array}$ & CSS & 004 & 39.9 & 17.0 & 0 & 13.0 & $255-300$ & $40-70$ & $260-280$ & 1.16 & $0.1-0.5$ & $\mathrm{n} / \mathrm{a}$ & 6.8 \\
\hline Larissa & ISS & 005 & 19.0 & 13.0 & 0 & 11.8 & 284 & 65 & 270 & 0.4 & $0.1-0.5$ & $0.5-1.5$ & 6.3 \\
\hline Asmaki & ISS & 004 & 11.0 & 10.0 & 0 & 9.4 & 273 & 70 & 270 & 0.25 & 0.1 & & 5.9 \\
\hline Tyrnavos & CSS & 001 & 19.7 & 16.4 & 0 & 14.0 & $275-290$ & $50-75$ & $260-280$ & 0.55 & $0.1-0.4$ & $\mathrm{n} / \mathrm{a}$ & 6.3 \\
\hline Tyrnavos & ISS & 001 & 14.0 & 13.0 & 0 & 11.8 & 279 & 65 & 280 & 0.3 & $0.1-0.4$ & $1.5-2.5$ & 6.1 \\
\hline $\begin{array}{c}\text { North Tyrnavos } \\
\text { Basin }\end{array}$ & CSS & 002 & 46.9 & 14.1 & 0 & 12.5 & $70-130$ & $55-75$ & $260-290$ & 0.47 & $0.1-1.0$ & $\mathrm{n} / \mathrm{a}$ & 6.2 \\
\hline Rodia & ISS & 002 & 15.0 & 13.0 & 0 & 11.8 & 109 & 65 & 280 & 0.3 & $0.1-1.0$ & & 6.1 \\
\hline Gyrtoni & ISS & 003 & 13.0 & 12.0 & 0 & 11.3 & 103 & 70 & 270 & 0.3 & $0.01-0.1$ & & 6.1 \\
\hline Omolio & CSS & 040 & 38.7 & 18.3 & 0 & 14.0 & $280-310$ & $40-70$ & $260-280$ & 0.74 & $0.4-0.9$ & $\mathrm{n} / \mathrm{a}$ & 6.5 \\
\hline $\begin{array}{c}\text { South Kassandra } \\
\text { offshore }\end{array}$ & CSS & 285 & 46.0 & 16.8 & 0 & 14.5 & $70-115$ & $50-80$ & $210-245$ & 1.34 & $0.8-1.4$ & $\mathrm{n} / \mathrm{a}$ & 6.9 \\
\hline Pelion offshore & CSS & 820 & 35.9 & 13.0 & 0 & 12.0 & $290-315$ & $60-80$ & $270-300$ & 1.0 & $0.7-1.4$ & $\mathrm{n} / \mathrm{a}$ & 6.7 \\
\hline Mavrovouni & CSS & 815 & 35.2 & 16.2 & 0 & 14.0 & $280-300$ & $50-80$ & $270-310$ & 1.16 & $0.7-1.6$ & $\mathrm{n} / \mathrm{a}$ & 6.8 \\
\hline
\end{tabular}

Table 6. Seismotectonic parameters of the CSSs and ISSs included in the Thessalian fault system (see Figure 7). CSS, composite seismogenic source; ISS, individual seismogenic source; Code, identification number within the database; n/a, not available.

here because of their parallelism with those on the land, and especially due to the sharp angular relationship with the CSSs described in the Northern Aegean offshore system (see chapter 6).

\subsection{Pagasitikos Gulf CSS (Volos and Nea Anchialos ISSs)}

As mentioned above, North Aegean Trough consists of three major CSSs. The easternmost is the ENE-WSWtrending Pagasitikos Gulf CSS (CSS code, 010) (Figure 7; Table 6). This dips southwards, controlling the northern coastline of the homonymous gulf and the margin of the Almyros Basin. Its total length is estimated as ca. $50 \mathrm{~km}$, taking into account that the zone probably extends further to the east, across the southern Pelion peninsula. The morphological expression of the fault zone, its morphotectonic features, and the two strongest events of the 1980 Magnesia earthquake sequence indicate that there are two distinct segments (the Volos and Nea Anchialos ISSs), with a right-stepping, partly overlapping, geometry.
The Volos ISS (ISS code, 010) is the eastern segment of the North Aegean Trough, and it lies almost totally offshore and controls the northern coastline of the gulf. Morphological indications suggest an onshore continuation across the Pelion peninsula, to reach a total length of $21 \mathrm{~km}$. The roughly E-W-trending fault scarp is well documented on the sea floor from bathymetric surveys, seismic profiles, and Holocene sediment distributions [Perissoratis et al. 1991]. The Volos ISS was responsible for the first strong shock $\left(\mathrm{M}_{\mathrm{w}}=6.5\right.$; July 9$)$ of the 1980 seismic sequence (Table 1). The calculated focal mechanisms of both the 1980 sequence and the April 30, $1985\left(\mathrm{M}_{\mathrm{s}}=\right.$ 5.5), event [Jackson et al. 1982, Papazachos et al. 1983, Dziewonski et al. 1988, Ekström and England 1989, Taymaz et al. 1991, Vannucci and Gasperini 2003, Vannucci and Gasperini 2004] generally fit the geological observations, showing ENEWSW-striking planes, shallow-dipping towards the SSE, with a normal dip-slip motion. A mean displacement of $0.63 \mathrm{~m}$ was calculated from empirical relationships. The $1980 \mathrm{M}_{\mathrm{w}}=6.5$ event probably represents the maximum expected magnitude. 
The western segment of the fault zone is the Nea Anchialos ISS (ISS code, 011), which borders the northern margin of Almyros Basin and partly controls the northern coastline of the Pagasitikos Gulf. It has a total length of 23 $\mathrm{km}$. It is the causative fault of the second strong earthquake $\left(M_{w}=6.1\right)$ of the 1980 sequence, which occurred 24 min after the first earthquake, suggesting a triggering phenomenon (Table 1). The mapped fault trace and co-seismic ruptures [Papazachos et al. 1983, Ambraseys and Jackson 1990, Caputo 1996] indicate an ENE-WSW strike and a SSE dip [Papazachos et al. 1983, Caputo and Pavlides 1991, Mountrakis et al. 1993a, Caputo 1995, 1996, Galanakis et al. 1998, Zovoili et al. 2004]. Microearthquake surveys delineate a south-dipping fault plane $\left(\mathrm{ca} .55^{\circ}\right)$ and a seismogenic layer thickness of ca. 12 km [Kementzetzidou 1996, Hatzfeld et al. 1999]. Both mesostructural analyses [Caputo and Pavlides 1991, Caputo and Pavlides 1993, Caputo 1996] and focal mechanisms [Jackson et al. 1982, Papazachos et al. 1983, Dziewonski et al. 1988, Ekström and England 1989, Taymaz et al. 1991, Vannucci and Gasperini 2003, Vannucci and Gasperini 2004] indicate normal faulting associated with a N-S extension. Based on geomorphic markers, a slip rate between $1 \mathrm{~mm} / \mathrm{a}$ and $3 \mathrm{~mm} / \mathrm{a}$ was estimated [Caputo 1996], and a recurrence interval of 1.5 ka has been suggested [Zovoili et al. 2004].

It is important to note that a possible breaching of these two segments in the future could produce a larger earthquake, with a magnitude as high as 7.0 [based on the empirical relationship of Wells and Coppersmith 1994].

\subsection{Vasilika CSS (Righeo and Dasolofos ISSs)}

Northwest of the Pagasitikos CSS (see §7.1) lies the Vasilika CSS (CSS code, 015), which obliquely crosses the Pliocene-Early Pleistocene Central Hills horst in an E-W to ESE-WNW direction, following a slightly curved fault trace (Figure 7; Table 6) [Caputo 1996]. The fault zone disappears under the Quaternary sediments of the Karditsa plain, and its westward continuation is uncertain. The mapped length of the neotectonic fault is ca. $50 \mathrm{~km}$. In the central-eastern sector, two major fault segments have been recognized [Caputo 1995]: the Righeo (ISS code 015) and Dasolofos (ISS code 016) ISSs, as east and west, respectively. The two segments have left-stepping, partly overlapping geometries, and show clear morphotectonic evidence for Late Pleistocene deposits [Caputo 1995, Caputo and Pavlides 1993]. Mesostructural analyses indicate a SSW-dipping setting and a normal dip-slip kinematics that is compatible with a roughly N-S direction of extension. The Righeo ISS is $22 \mathrm{~km}$ long, while the Dasolofos ISS is $15 \mathrm{~km}$ long. A microearthquake cluster has been instrumentally recorded within this seismogenic volume, thus documenting a seismogenic depth of at least $12 \mathrm{~km}$ to $13 \mathrm{~km}$ and $60^{\circ}$ to $70^{\circ}$ mean dip [Kementzetzidou 1996, Hatzfeld et al. 1999]. On March 8, 1957, two strong earthquakes occurred near Velestino $\left(\mathrm{M}_{\mathrm{s}}=6.5\right.$ and 6.6, according to Ambraseys and
Jackson 1990; or $\mathrm{M}_{\mathrm{w}}=6.4$ according to Vannucci and Gasperini 2003, 2004] (Table 1), and these have been associated with this fault zone [Caputo 1995]. Although the poor seismological recordings and especially the time difference of 7 min between the two earthquakes hamper the separate reconstruction of these two macroseismic fields, a possible triggering effect can be tentatively suggested. Considering the magnitudes, it is likely that both segments (partly) ruptured. Ground ruptures were reported by local people only along the Righeo ISS [Ambraseys and Jackson 1990]. The mean displacements were calculated to be $0.8 \mathrm{~m}$ and $0.6 \mathrm{~m}$, and the maximum expected magnitudes, according to the empirical relationship of Wells and Coppersmith [1994], were calculated as 6.5 and 6.3 for these two ISSs, respectively.

\subsection{Domokos CSS (Ekkara ISS)}

The westernmost seismogenic structure of the southern Thessaly fault belt is represented by the Domokos CSS (CSS code, 020) (Figure 7; Table 6), which is antithetic (i.e. NNE-dipping) with respect to the Pagasitikos and Vasilika CSSs (see $\S \S 7.1,7.2$ ). The fault trace is marked by a curvilinear scarp, which varies in strike from E-W to (W)NW(E)SE, moving westwards. This is due to the interaction and linkage of an inherited WNW-ESE trending fault system with a more recent one, trending E-W. Based on geological and morphotectonic investigations [Caputo and Pavlides 1993, Pavlides 1993], the total length can be roughly estimated as $48 \mathrm{~km}$, while mesostructural analyses document dip-slip to oblique-slip motions that are compatible with a NNE-SSW direction of extension [Caputo 1995]. The central sector of the fault zone (Ekkara ISS; ISS code, 020) ruptured in the April 30, 1954, Sophades earthquake, which produced several kilometer-long ground ruptures [Papastamatiou and Mouyiaris 1986] (Table 1). The initially assessed surface magnitude was 7.0 [Papastamatiou and Mouyiaris 1986], but this was probably an overestimation $\left(M_{s}=6.7\right.$, Ambraseys and Jackson 1990; $\mathrm{M}_{\mathrm{w}}=6.6$, Vannucci and Gasperini 2003, 2004]. Recent palaeoseismological investigations clearly document that this structure ruptured in the past, and suggest a minimum slip rate of $0.3 \mathrm{~mm} / \mathrm{a}$ to 0.5 $\mathrm{mm} / \mathrm{a}$, and a recurrence interval greater than $3 \mathrm{ka}$ [Palyvos et al. 2010]. The total length of the Ekkara ISS was estimated to be $29 \mathrm{~km}$. The focal mechanism proposed by Vannucci and Gasperini [2003, 2004] suggests a WNW-tending, NNE-dipping rupture plane, which is slightly different from that proposed by McKenzie [1972].

\subsection{South Tyrnavos Basin CSS (Larissa and Asmaki ISSs)}

As mentioned above, northern Thessaly is characterized by very low historical and instrumental seismicity, but prominent neotectonic structures show evidence of recent activity. The geological similarity and the contrasting seismological records suggest that there has been a seismic 
gap in the northern Larissa plain [Caputo 1995]. One of these neotectonic structures is the South Tyrnavos Basin CSS (CSS code, 004) (Figure 7; Table 6), which borders the homonymous graben to the south, and shows a NNE-dipping setting with a normal dip-slip kinematics [Caputo et al. 1994]. The fault zone is ca. $40 \mathrm{~km}$ long. Two segments have been recognized: the Larissa (ISS code, 005) and Asmaki (ISS code, 004) ISSs (west and east, respectively).

The Larissa ISS is associated with a prominent fault scarp that separates Pliocene-Early Pleistocene deposits of the Central Hills in the footwall from recent alluvial sediments of the Pinios River that fill the hanging-wall basin. Based on geological and morphotectonic investigations and on geophysical surveys the fault has a length of $19 \mathrm{~km}$ and a mean ESE-WNW orientation [Caputo and Pavlides 1993, Caputo et al. 2003]. The eastern tip corresponds to an angular barrier and a left-stepping underlapping geometry with the nearby structure. Based on empirical relationships, the maximum expected magnitude is estimated to be 6.8 , while the slip rate ranges from $0.1 \mathrm{~mm} / \mathrm{a}$ to $0.5 \mathrm{~mm} / \mathrm{a}$ [Caputo 1995].

In the eastern sector, morphological evidence is more subtle, probably due to an overall lower slip rate. However, recent tectonic activity is well documented by the occurrence of few meters high, but several kilometres long, E-Wtrending scarps affecting the Holocene sediments of the Larissa plain [Caputo et al. 1994] and documenting three subparallel overlapping sub-emergent fault planes. One of these structures (Asmaki ISS) is ca. $11 \mathrm{~km}$ long and was probably ruptured in the March 1, 1941, Larissa earthquake (Table 1), based on the occurrence of co-seismic ground ruptures along one of these morphological alignments [Ambraseys and Jackson 1990, Caputo 1995]. The focal mechanism indicates a NNE-dipping slightly oblique-slip nodal plane, while the magnitude of this event was $\mathrm{M}_{\mathrm{w}}=6.1$ [Vanucci and Gasperini 2003, 2004], or $\mathrm{M}_{\mathrm{e}}=6.3$ according to Papazachos and Papazachou [1997]. Although the eastern sector of the South Tyrnavos Basin CSS is longer than the Asmaki Fault, due to the above mentioned slip partitioning, the 1941 event possibly represents the maximum expected magnitude.

\subsection{Tyrnavos CSS (Tyrnavos ISS)}

The Tyrnavos CSS (CSS code, 001) (Figure 7; Table 6) is parallel to and synthetic with the South Tyrnavos Basin CSS (see $§ 7.4$ ). With the latter structure, the Tyrnavos CSS forms a largely overlapping, right-stepping geometry that trends ESE-WNW and has a total length of at least $20 \mathrm{~km}$. The bestdefined section of the fault is constrained to a length of 14 $\mathrm{km}$, and this is conservatively represented by the Tyrnavos ISS (ISS code, 001), which forms a prominent scarp that affects the Triassic rocks as well as Pliocene and Late Quaternary sediments [Caputo 1993a, 1995]. A continuous unweathered fresh scarp and 10-15-cm-high free-faces probably document recent co-seismic ruptures [Caputo 1993a].
The displacement of the latest Pleistocene-Holocene alluvial deposits along an 8-10-m-high scarp, as well as borehole data, suggest a long-term slip-rate between $0.1 \mathrm{~mm} / \mathrm{a}$ and $0.4 \mathrm{~mm} / \mathrm{a}$ [Caputo 1993a, Caputo et al. 2004a, 2006]. The fault surface has also been detected from geophysical surveys: ground-penetrating radar [Caputo and Helly 2000], electrical resistivity tomography [Caputo et al. 2003] and horizontal-to-vertical spectral ratios [Oliveto et al. 2004]. The results of several palaeoseismological trenches document the occurrence of at least 12 or 13 events during the last $25 \mathrm{ka}$ to $30 \mathrm{ka}$, and a mean recurrence interval of $1.5 \mathrm{ka}$ to $2.5 \mathrm{ka}$ [Caputo and Helly 2007]. After using the empirical relationship of Wells and Coppersmith [1994], the maximum expected magnitude for the ISS is ca. 6.1, while the reactivation of the whole CSS could generate a 6.3 event.

\subsection{North Tyrnavos Basin CSS (Rodia and Gyrtoni ISSs)}

The Tyrnavos Basin is bounded to the north by another major CSS (North Tyrnavos Basin; CSS code, 002) that is antithetic to and faces towards the previously described CSSs (Figure 7; Table 6). The fault zone is characterized by an articulated geometry, due to the linkage of inherited NW-SEtrending segments and newly formed $\mathrm{E}(\mathrm{SE})-\mathrm{W}(\mathrm{NW})$-trending segments [Caputo 1993b, Caputo and Helly 2005b]. Geological, structural, morphotectonic and geophysical investigations have allowed the mapping of this CSS in detail and the documentation of its recent activity [Caputo 1993b, Caputo 1995, Caputo and Pavlides 1993, Caputo et al. 1994, Caputo et al. 2003]. The activity is further confirmed by the results of palaeoseismological trenches [Caputo and Helly 2000, Caputo et al. 2004b, Caputo and Helly 2005b]. Mesostructural analyses have indicated a NNE-SSW direction of extension [Caputo 1993b]. The total length of this fault zone is ca. 47 $\mathrm{km}$. There are two major recognized fault segments: the Rodia (ISS code, 002) and Gyrtoni (ISS code, 003) ISSs [Caputo 1993b, Caputo 1995, Caputo and Pavlides 1993, Caputo et al. 1994, Goldsworthy and Jackson 2000], which bear the best evidence of recent activity.

The Rodia ISS is $15 \mathrm{~km}$ long and trends in an ESE-WNW direction. It separates the Palaeozoic metamorphic rock of the Pelagonian Zone to the north from the Pleistocene and Holocene sediments to the south. The latter consists of scree deposits that come from the mountain front, interfingered with the alluvial deposits of the Pinios River. Palaeoseismological investigations document a Holocene linear morphogenic earthquake that has been dated 2-3 ka BP, with a vertical displacement of $25 \mathrm{~cm}$ to $30 \mathrm{~cm}$, and a possible magnitude of $6.4 \pm 0.2$ [Caputo and Helly 2005b]. With the addition of morphotectonic and stratigraphic data, a slip rate ranging between $0.1 \mathrm{~mm} / \mathrm{a}$ and $1.0 \mathrm{~mm} / \mathrm{a}$ has been suggested.

The Gyrtoni ISS is parallel to and synthetic with the Rodia ISS, and shows right-stepping, underlapping geometry. The fault is $13 \mathrm{~km}$ long and is mainly marked by a morphological 
scarp that separates Villafranchian lacustrine deposits (the footwall) from Holocene alluvial sediments [Caputo et al. 1994]. Further evidence of its recent activity comes from highresolution geophysical investigations [Caputo et al. 2003].

The seismogenic layer thickness of the area is believed to be $12.5 \mathrm{~km}$, from interpolation between the areas of the Aliakmonas and Pagasitikos CSSs. The maximum expected magnitude of each fault is 6.1 [using the empirical relationship of Wells and Coppersmith 1994], with a corresponding co-seismic mean displacement of $0.3 \mathrm{~m}$. The complex geometry of the CSS suggests scenarios of total rupture are not likely.

\subsection{Omolio CSS}

The Omolio CSS (CSS code, 040) is the northernmost active structure of the Thessalian fault system (Figure 7; Table 6). It is ESE-WNW trending and NNE dipping, and it separates the Palaeozoic-Mesozoic bedrock from the Holocene alluvial and deltaic deposits of the Pinios River (eastern sector) [Caputo 1990]. Together with the antithetic and diverging North Tyrnavos Basin CSS (see $\S 7.6$ ), the Omolio CSS delimits the Gonnoi Horst, which was strongly uplifted in recent times [Stiros et al. 2004]. This CSS is associated with a $39-\mathrm{km}$-long fault zone that shows evidence of recent tectonic activity, such as a major linear escarpment and several suspended wine-glass valleys. On June 9, 2003, a moderate earthquake $\left(\mathrm{M}_{\mathrm{w}}=5.3\right)$ hit the area, with a focal mechanism in agreement with the CSS geometry and kinematics [Pavlides et al. 2004b]. The event was probably associated with this seismogenic volume, but was too deep and small to produce any clear surface expression. On the basis of the CSS dimensions and the empirical relationship of Wells and Coppersmith [1994], the maximum expected magnitude is 6.5.

\subsection{South Kassandra offshore CSS}

The South Kassandra offshore CSS (CSS code, 285) is the western continuation of the South Chalkidiki offshore CSS (see $\S 6.1$ ), although it is characterized by a marked orientation change along its strike, from E-W to ESE-WNW (Figure 7; Table 6). Its total length is $46 \mathrm{~km}$, and the motion is probably pure dip-slip normal [Brooks and Ferentinos 1980, Papanikolaou et al. 2002]. It is associated with a major submarine escarpment that follows the coastline of the Kassandra peninsula. Its recent activity has been inferred from high-resolution seismic reflection profiles [Papanikolaou et al. 2006], which show clear downthrow of the southern block and deformation of the sea-floor sediments. The estimated maximum expected magnitude and slip per event are 6.9 and $1.34 \mathrm{~m}$, respectively.

\subsection{Pelion offshore CSS}

The Pelion offshore CSS (CSS code, 820) follows the southwestern border of the North Aegean Basin, offshore from the eastern Pelion peninsula, and north of Skiathos and
Skopelos Islands. It is represented by a (W)NW-(E)SE trending fault zone (Figure 7; Table 6). This tectonic structure is ca. $36 \mathrm{~km}$ long, and it is NE-dipping, as emphasized by a steep morphological submarine slope [Papanikolaou et al. 2002]. The location and geometry of the fault zone and its recent activity are also clear in the seismic reflection profiles, which show that it has displaced and deformed the sea-bottom sediments [Laigle et al. 2000, Papanikolaou et al. 2006]. Based on its orientation and the geodynamic setting, the motion should be slightly oblique-slip, but with a prevailing normal dip-slip component. The estimated maximum expected magnitude and slip per event are 6.7 and $1.0 \mathrm{~m}$, respectively.

\subsection{Mavrovouni offshore}

Located at the western margin of the North Aegean Basin (Figure 7; Table 6), Mavrovouni CSS (CSS code, 815) shows similar characteristics to the southern, parallel and synthetic Pelion offshore CSS (see $\S 7.9$ ). Identified as slightly oblique-slip with a prevailing normal dip-slip component structure [Papanikolaou and Papanikolaou 2007], this CSS clearly affects the sea-floor morphology [Papanikolaou et al. 2002]. Seismic reflection profiles carried out across this fault clearly document displacement and deformation of the seafloor sediments [Papanikolaou et al. 2006]. The fault complexity towards the basin does not allow good constraint of its continuation further east. The estimated maximum expected magnitude and slip per event are 6.8 and $1.16 \mathrm{~m}$, respectively.

\section{Concluding remarks}

Since the beginning of the GreDaSS Project, more than 35 CSSs and 55 ISSs have been recognized, studied and analyzed in the pilot area of northern Greece, while many seismogenic sources are in progress for the rest of the Greek territory. Several ISSs have been directly and confidently associated with recent instrumentally recorded earthquakes, and even more have been related to historical events, with many recognized as individual segments. The great majority of the ISSs belong to larger fault zones represented by CSSs. It is important to recall that although the database has been expanded to the rest of the Aegean Region, the selection of northern Greece as a pilot area is because this region has the highest level of completeness for both seismogenic sources and their associated metadata, according to our present knowledge. However, it would be utopic to believe that this is the final picture for this area. Difficulties in investigating, documenting and recognising active faults are evident in cases of offshore areas (e.g. the Aegean Sea) or areas where the lithology does not allow the preservation of the fault scarps (e.g. the prevailing clastic deposits in Epirus), which implies the occurrence of a possible information gap that will hopefully be resolved in future investigations.

One of the main purposes of the GreDaSS and its con- 
tribution to the SHARE Project is to participate in the computational infrastructure for SHA that will produce an integrated European probabilistic SHA (PSHA) model and specific scenario-based modeling tools that will deliver a longlasting structural impact in areas of social and economic relevance. It will also serve as a reference for the Eurocode 8 application, by providing homogeneous input for correct seismic safety assessments for critical industries, such as the energy infrastructures and the re-insurance sector. Beyond the scope of enhancing SHA, the GreDaSS can also facilitate better understanding and better modeling of the geodynamics and seismotectonic setting of the whole Aegean Region.

Based on the three-dimensional structure (geometry) of many seismogenic sources, observations on fault clustering and regional patterns, homogeneity of the data concerning the kinematic behavior, and comparisons of similar well known structures out of, but near to, the study area (i.e. the Gulf of Corinth), the occurrence of several low-angle normal detachment fault zones can be inferred for the mainland of northern Greece [Sboras and Caputo 2010]. For example, the fault system of Mygdonia Basin probably has its roots in the N-dipping, low-angle shear zone of the Anthemountas CSSs [Tranos et al. 2003]. Similarly, in the Kozani area, the Palaeochori ISS can be interpreted as a northern splay of the shallow NNW-dipping structure of Deskati DSS [Chiarabba and Selvaggi 1997, Hatzfeld et al. 1997, Hatzfeld et al. 1998, Doutsos and Koukouvelas 1998]. A comparable geological and tectonic setting can be envisaged for the Ptolemaida Basin [Sboras and Caputo 2010].

Moreover, the processes that provide homogeneity during data collection and parameterization of the seismogenic sources in the database have allowed us to roughly distinguish five sectors that show common geometrical and geodynamic characteristics: (i) a northern E-W-trending fault belt in Thrace and Eastern Macedonia; (ii) a complex E(SE)$\mathrm{W}(\mathrm{NW})$-trending fault system that affects the Chalkidiki peninsula and its possibly associated low-angle detachments; (iii) the NE-SW-trending anti-Hellenic fault system in western Macedonia and Epirus; (iv) the $\mathrm{E}(\mathrm{SE})-\mathrm{W}(\mathrm{NW})$-trending Thessalian fault system; and (v) the (E)NE-(W)SW-trending North Aegean Sea fault system, which is almost exclusively located offshore. These sectors probably correspond to major crustal (and lithospheric?) blocks that are characterized by partially independent behaviors, at least during the Quaternary, although they could also be associated with the occurrence of older inherited structures.

This report attempts to provide a contribution towards synthesizing and standardizing published and new data, and is aimed at more precise SHA for northern Greece and to provide assistance for the refinement of the current seismic zonation of the area. Given that the GreDaSS is in continuous development and that many seismogenic sources in the remaining Aegean Region have at least been preliminarily as- sessed for all of the necessary seismotectonic parameters, we expect that in the near future more sectors of the database will be released and published.

Acknowledgements. For each seismotectonic parameter included in the GreDaSS, we performed a throughout critical analysis of all available material, both published and unpublished. Due to space limitations, however, it is not possible to refer to all of the references consulted for this report, which are instead included and specified in the database. We apologize to all of these 'omitted' Authors. The Italian Ministry of Education and the University of Ferrara provided a 3-year grant to S.S. Financial contributions by the INGV and the EU SHARE Project are also acknowledged. Gianluca Valensise, Roberto Basili and Vanja Kastelic are thanked for their scientific discussions and for providing the informatic infrastructure of the database. Careful reviewing by Nicola Litchfield and an anonymous reviewer contributed to the improvement of the previous version of the manuscript.

\section{References}

Altunel, E., M. Meghraoui, H.S. Akyüz and A. Dikbas (2004). Characteristics of the 1912 co-seismic rupture along the North Anatolian Fault Zone (Turkey): implications for the expected Marmara earthquake, Terra Nova, 16, 198204.

Ambraseys, N.N., and C.F. Finkel (1987). The Saros-Marmara earthquake of 9 August 1912, Earthq. Eng. Struct. Dyn., 15, 189-211.

Ambraseys, N.N., and J.A. Jackson (1990). Seismicity and associated strain of central Greece between 1890 and 1988, Geophys. J. Int., 101, 663-708.

Ambraseys, N.N., and J.A. Jackson (1998). Faulting associated with historical and recent earthquakes in the eastern Mediterranean region, Geophys. J. Int., 133, 390-406.

Ambraseys, N.N. (1999). Early earthquakes in the Kozani Area, northern Greece, Tectonophysics, 308, 291-298.

Ambraseys, N.N. (2001). Reassessment of earthquakes, 19001999, in the eastern Mediterranean and the Middle East, Geophys. J. Int., 145, 471-485.

Ambraseys, N.N. (2002). The seismic activity of the Marmara Sea Region over the last 2000 years, Bull. Seism. Soc. Am., 92, 1-18.

Ambraseys, N.N. (2009). Earthquakes in the Mediterranean and Middle East: A Multidisciplinary Study of Seismicity up to 1900, Cambridge University Press, Cambridge, 968 pp.

Anderson, H., and J. Jackson (1987). Active tectonics of the Adriatic Region, Geophys. J. Roy. Astr. Soc., 91, 937-983.

Angelier, J. (1979). Néotectonique de l'Arc Égéen, Soc. Géol. Nord, Spéc. Publ., 3, 418 pp.

Armijo, R., B. Meyer, A. Hubert and A. Barka (1999). Westward propagation of the North Anatolian fault into the northern Aegean: Timing and kinematics, Geology, 27, 267-270.

Atzemoglou, A., P. Tsourlos and S. Pavlides (2003). Investigation of the tectonic structure of the NW part of the Amynteon Basin (NW Greece) by means of a vertical 
electrical sounding (VES) survey, J. Balkan Geophys. Soc., 6 (4), 188-201.

Baker, C., D. Hatzfeld, H. Lyon-Caen, E. Papadimitriou and A. Rigo (1997). Earthquake mechanisms of the Adriatic Sea and western Greece. Geophys, J. Int., 131, 559-594.

Barker, J.S., and C.A. Langston (1981). Inversion of teleseismic body waves for the moment tensor of the 1978 Thessaloniki, Greece, earthquake, Bull. Seism. Soc. Am., 71, 1423-1444.

Basili, R., G. Valensise, P. Vannoli, P. Burrato, U. Fracassi, S. Mariano, M.M. Tiberti and E. Boschi (2008). The database of individual seismogenic sources (DISS), version 3: summarizing 20 years of research on Italy's earthquake geology, Tectonophysics, 453 (1-4), 20-43.

Boccaletti, M., R. Caputo, D. Mountrakis, S. Pavlides and N. Zouros (1997). Paleoseismicity of the Souli Fault, Epirus, western Greece, J. Geodyn., 24 (1-4), 117-127.

Brooks, M., and G. Ferentinos (1980). Structure and evolution of the Sporadhes basin of the North Aegean trough, Tectonophysics, 68, 15-30.

Çagatay, M.N., N. Görür, B. Alpar, R. Saatçilar, R. Akkök, : Sakinç, H. Yüce, C. Yaltirak and I. Kuscu (1998). Geological evolution of the Gulf of Saros, NE Aegean Sea, GeoMar. Lett., 18, 1-9.

Caputo, M., G.F. Panza and D. Postpischil (1970). Deep structure of the Mediterranean Basin, J. Geophys. Res., 75, 4919-4923.

Caputo, R. (1990). Geological and structural study of the recent and active brittle deformation of the Neogene-Quaternary basins of Thessaly (Greece), Scientific Annals, 12, Aristotle University of Thessaloniki, 2 vols., 5 encl., 252 pp.

Caputo, R., and S. Pavlides (1991). Neotectonics and structural evolution of Thessaly (central Greece), Bull. Geol. Soc. Greece, 25 (3), 119-133.

Caputo, R. (1993a). Morphotectonics and kinematics of the Tyrnavos Fault, northern Larissa plain, Greece, Z. Geomorph. N. E., 94, 167-185.

Caputo, R. (1993b). The Rodia fault system: an active complex shear zone (Larissa plain, Central Greece), Bull. Geol. Soc. Greece, 28 (1), 447-456.

Caputo, R., and S. Pavlides (1993). Late Cainozoic geodynamic evolution of Thessaly and surroundings (centralnorthern Greece), Tectonophysics, 223, 339-362.

Caputo, R., and N. Zouros (1993). Examples of Alpide deformation from Epirus: local anomalies or need to reevaluate the amount of shortening in the western Hellenides?, Bull. Geol. Soc. Greece, 28 (1), 315-326.

Caputo, R., J.-P. Bravard and B. Helly (1994). The PlioceneQuaternary tecto-sedimentary evolution of the Larissa Plain (eastern Thessaly, Greece), Geodinamica Acta, 7 (4), 219-231.

Caputo, R. (1995). Inference of a seismic gap from geologi- cal data: Thessaly (Central Greece) as a case study, Annali di Geofisica, 38 (1), 1-19.

Caputo, R. (1996). The active Nea Anchialos Fault System (central Greece): comparison of geological, morphotectonic, archaeological and seismological data, Annali di Geofisica, 39 (3), 557-574.

Caputo, R., and B. Helly (2000). Archéosismicité de l'Égée: étude des failles actives de la Thessalie, Bull. Corresp. Hell., 124 (2), 560-588.

Caputo, R., S. Piscitelli, A. Oliveto, E. Rizzo and V. Lapenna (2003). The use of electrical resistivity tomography in active tectonics. Examples from the Tyrnavos Basin, Greece, J. Geodyn., 36 (1-2), 19-35.

Caputo, R., B. Helly, S. Pavlides and G. Papadopoulos (2004a). Palaeoseismological investigation of the Tyrnavos Fault (Thessaly, central Greece), Tectonophysics, 394, 1-20.

Caputo R., A. Oliveto and B. Helly (2004b). Palaeoseismological researches along the Rodia Fault, central Greece, Proceedings of 5th International Symposium on Eastern Mediterranean Geology, 14-20 April 2004, Thessaloniki, Greece, Ref: S2-6.

Caputo, R. (2005). Ground effects of large morphogenic earthquakes, J. Geodyn., 40 (2-3), 113-118.

Caputo, R., and B. Helly (2005a). Archaeological evidences of past earthquakes: a contribution to the SHA of Thessaly, Central Greece, J. Earthq. Eng., 9 (2), 199-222.

Caputo, R., and B. Helly (2005b). The Holocene activity of the Rodia Fault, central Greece, J. Geodyn., 40, 153-169.

Caputo, R., B. Helly, S. Pavlides and G. Papadopoulos (2006). Archaeo- and palaeoseismological investigations in northern Thessaly (Greece): Insights for the seismic potential of the region, Nat. Hazards, 39, 195-212.

Caputo, R., and B. Helly (2007). The European Palaeoseismological Museum of Tyrnavos, central Greece, EGU General Assembly, Vienna, April 16-20, 2007, Geophysical Research Abstracts, 9, 00283.

Caputo, R., S. Pavlides and M. Mucciarelli (2008). Magnitude distribution of linear morphogenic earthquakes in the Mediterranean Region: insights from palaeoseismological and historical data, Geophys. J. Int., 174, 930-940; doi: 10.1111/j.1365-246X.2008.03834.X.

Carver, D., and G.A. Bollinger (1981). Aftershocks of the June 20, 1978 Greece earthquake: a multimode faulting sequence, Tectonophysics, 73, 343-363.

Chatzipetros, A. (1998). Paleoseismological and morphotectonic study of the active fault systems at Mygdonia basin, eastern Chalkidiki and Kozani-Grevena, PhD Thesis, Aristotle University of Thessaloniki, Greece, 354 pp. (in Greek).

Chatzipetros, A.A., S.B. Pavlides and D.M. Mountrakis (1998). Understanding the 13 May 1995 western Macedonia earthquake: a paleoseismological approach, J. Ge- 
odyn., 26 (2-4), 327-339.

Chatzipetros, A., and S. Pavlides (2004). Geometry and kinematics of the Maronia-Makri active fault (Thrace, northeastern Greece), 4th National Geophysical Conference of the Bulgarian Geophysical Society, October 4-5, 2004, Sofia, Bulgaria, Session 1, 61-63.

Chatzipetros, A., S. Pavlides and O. Mourouzidou (2004). Reevaluation of Holocene earthquake activity in Mygdonia Basin, Greece, based on new paleoseismological results, 5th Int. Symp. East. Mediterr. Geol., Ref: S2-15.

Chatzipetros, A., A. Michailidou, Th. Tsapanos and S. Pavlides (2005). Morphotectonics and seismotectonics of the Stratoni-Barbara and Gomati-Megali Panagia active fault (eastern Chalkidiki, northern Greece), Bull. Geol. Soc. Greece, XXXVII, 127-142.

Cheng, S., Z. Fang, S. Pavlides and A. Chatzipetros (1994). Preliminary study of paleoseismicity of the southern Langada-Volvi basin margin fault zone, Thessaloniki, Greece, Bull. Geol. Soc. Greece, 30 (1), 401-407.

Chiarabba, C., and G. Selvaggi (1997). Structural central on fault geometry: example of the Grevena Ms 6.6, normal faulting earthquake, J. Geophys. Res., 102, 22 445-22 457.

Coskun, B. (2000). North Anatolian Fault-Saros Gulf relationships and their relevance to hydrocarbon exploration, northern Aegean Sea, Turkey, Mar. Petrol. Geol., 17, 751772.

Diamantopoulos, A. (2006). Plio-Quaternary geometry and kinematics of Ptolemais Basin (northern Greece): Implications for the intra-plate tectonics in western Macedonia, Geologia Croatica, 59 (1), 85-96.

Doutsos, T., and I. Koukouvelas (1998). Fractal analysis of normal faults in northwestern Aegean area, Greece, J. Geodyn., 26 (2-4), 197-216.

Doutsos, T., and S. Kokkalas (2001). Stress and deformation patterns in the Aegean region, J. Struct. Geol., 23, 455472.

Drakopoulos, J.C., and A.C. Economides (1972). Aftershocks of February 19, 1968 earthquake in northern Aegean Sea and related problems, Pure Appl. Geophys., 95, 100-115.

Dziewonski, A.M., A. Friedman, D. Giardini and J.H. Woodhouse (1983). Global seismicity of 1982: centroid-moment tensor solutions for 308 earthquakes, Phys. Earth Planet. Inter., 33, 76-90.

Dziewonski, A.M., J.E. Franzen and J.H. Woodhouse (1984). Centroid-moment tensor solutions for July-September, 1983, Phys. Earth Planet. Inter., 34, 1-8.

Dziewonski, A.M., J.E. Franzen and J.H. Woodhouse (1985). Centroid-moment tensor solutions for July-September, 1984, Phys. Earth Planet. Inter., 38, 203-213.

Dziewonski, A.M., J.E. Franzen and J.H. Woodhouse (1986). Centroid-moment tensor solutions for October-December 1985, Phys. Earth Planet. Inter., 43, 185-195.

Dziewonski, A.M., G. Ekström, J.E. Franzen and J.H. Wood- house (1987). Global seismicity of 1978: centroid-moment tensor solutions for 512 earthquakes, Phys. Earth Planet. Inter., 46, 316-342.

Dziewonski, A.M., G. Ekström, J.E. Franzen and J.H. Woodhouse (1988). Global seismicity of 1980: centroid-moment tensor solutions for 515 earthquakes, Phys. Earth Planet. Inter., 50, 127-154.

Dziewonski, A.M., G. Ekström, J.H. Woodhouse and G. Zwart (1991). Centroid-moment tensor solutions for October-December 1990, Phys. Earth Planet. Inter., 68, 201214.

Dziewonski, A.M., G. Ekström and M.P. Salganik (1996). Centroid-moment tensor solutions for April-June 1995, Phys. Earth Planet. Inter., 96, 1-13.

Dziewonski, A.M., G. Ekström, N.N. Maternovskaya and M.P. Salganik (1997). Centroid-moment tensor solutions for July-September, 1996, Phys. Earth Planet. Inter., 102, 133-143.

Ekström, G., A.M. Dziewonski and J.H. Woodhouse (1987). Centroid-moment tensor solutions for the 51 IASPEI selected earthquakes, 1980-1984, Phys. Earth Planet. Inter., 47, 62-66.

Ekström, G., and P. England (1989). Seismic strain rates in regions of distributed continental deformation, J. Geophys. Res., 94 (B8), 10231-10257.

Ferentinos, G., M. Brooks and M. Collins (1981). Gravity-induced deformation on the north flank and floor of the Sporadhes Basin of the North Aegean Sea Trough, Mar. Geol. Mar. Geol., 44, 289-302.

Floras, D. (1933). The destructions of the Chalkidiki earthquakes, Tech. Chron., 25, 21-28 (in Greek).

Galanakis, D., S. Pavlides and D. Mountrakis (1998). Recent brittle tectonic in Almyros-Pagasitikos, Maliakos, N. Euboea and Pilio, Bull. Geol. Soc. Greece, 42 (1), 263-273.

Galanakis, D., P. Paschos, T. Rondoyanni and C. Georgiou (2007). Neotectonic activity of Konitsa area and the 1996 earthquakes, Hell. J. Geosciences, 42, 57-64.

Galanis, O.C., C.B. Papazachos, P.M. Hatzidimitriou and E.M. Scordilis (2004). Application of 3-D velocity models and ray tracing in double difference earthquake location algorithms: application to the Mygdonia basin (northern Greece), Bull. Geol. Soc. Greece, 36 (3), 1396-1405.

Ganas, A., S.B. Pavlides, S. Sboras, S. Valkaniotis, S. Papaioannou, G.A. Alexandris, A. Plessa and G.A. Papadopoulos (2004). Active fault geometry and kinematics in Parnitha Mountain, Attica, Greece, J. Struct. Geol., 26, 2103-2118.

Gautier, P., J.-P. Brun, R. Moriceau, D. Sokoutis, J. Martinod and L. Jolivet (1999). Timing, kinematics and cause of Aegean extension: a scenario based on a comparison with simple analogue experiments, Tectonophysics, 315, 31-72; doi:10.1016/S0040-1951(99)00281-4.

Georgalas, G., and A. Galanopoulos (1953). Das grosse Erd- 
beben der Chalkidike vom 26 September 1932, Bull. Geol. Soc. Greece, 1, 11-63.

Goldsworthy, M., and J. Jackson (2000). Active normal fault evolution in Greece revealed by geomorphology and drainage patterns, Geol. Soc. London, 157, 967-981.

Goldsworthy, M., and J. Jackson (2001). Migration of activity within normal fault systems: examples from the Quaternary of mainland Greece, J. Struct. Geol., 23, 489-506.

Goldsworthy, M., J. Jackson and J. Haines (2002). The continuity of active fault systems in Greece, Geophys. J. Int., 148, 596-618.

Guidoboni, E., A. Comastri and G. Traina (1994). Catalogue of ancient earthquakes in the Medi-terranean area up to 10th century, INGV and SGA, Bologna, $504 \mathrm{pp}$.

Guidoboni, E., and A. Comastri (2005). Catalogue of earthquakes and tsunamis in the Mediterranean area from the 11 th to the 15th century, INGV and SGA, Bologna, $1037 \mathrm{pp}$.

Hanks, T.C., and H. Kanamori (1979). A moment magnitude scale, J. Geophys. Res., 84 (B5), 2348-2350.

Hatzfeld, D., A.A. Christodoulou, E.M. Scordilis, D. Panagiotopoulos and P.M. Hatzidimitriou (1986/87). A microearthquake study of the Mygdonian graben (northern Greece), Earth Planet. Sci. Lett., 81, 379-396.

Hatzfeld, D., I. Kassaras, D. Panagiotopoulos, D. Amorese, K. Makropoulos, G. Karakaisis and O. Coutant (1995). Microseimicity and strain pattern in northwestern Greece, Tectonics, 14, 773-785.

Hatzfeld, D., V. Karakostas, M. Ziazia, G. Selvaggi, S. Lebogne, C. Berge, R. Guiguet, A. Paul, P. Voidomatis, D. Diagourtas, I. Kassaras, I. Koutsikos, K. Makropoulos, R. Azzara, M. Di Bona, S. Baccheschi, P. Bernard and C. Papaioannou (1997). The Kozani-Grevena (Greece) earthquake of 13 May 1995 revisited from a detailed seismological study, Bull. Seism. Soc. Am., 87, 463-473.

Hatzfeld, D., V. Karakostas, M. Ziazia, G. Selvaggi, S. Lebogne, C. Berge and K. Makropoulos (1998). The Kozani-Grevena (Greece) earthquake of May 13, 1995, a seismological study, J. Geodyn., 26, 245-254.

Hatzfeld, D. (1999). The present-day tectonics of the Aegean as deduced from seismicity, In: B. Durand, L. Jolivet, F. Horvath and M. Séranne (eds.), The Mediterranean Basins: Tertiary extension within the Alpine orogen, Geol. Soc. London, Spec. Publ. n. 156, 415-526.

Hatzfeld, D., M. Ziazia, D. Kementzetzidou, P. Hatzidimitriou, D. Panagiotopoulos, K. Makropoulos, P. Papadimitriou and A. Deschamps (1999). Microseismicity and focal mechanisms at the western termination of the North Anatolian Fault and their implications for continental tectonics, Geophys. J. Int., 137, 891-908.

IOC (Intergovernmental Oceanographic Commssion) (1981). International bathymetric chart of the Mediterranean. Head Department of Navigation and Oceanography, Ministry of Defence, Leningrand, USSR, 1st edition.

Jackson, J.A., G. King and C. Vita-Finzi (1982). The neotectonics of the Aegean: an alternative view, Earth Planet. Sci. Lett., 61, 303-318.

Jackson, J., J. Haines and W. Holt (1992). The horizontal velocity field in the deforming Aegean Sea region determined from the moment tensors of earthquakes, J. Geophys. Res., 97, 17657-17684.

Janssen, C., M. Bohnhoff, Y. Vapnik, E. Görgün, F. Bulut, B. Plessen, D. Pohl, M. Aktar, A.I. Okay and G. Dresen (2009). Tectonic evolution of the Ganos segment of the North Anatolian Fault (NW Turkey), J. Struct. Geol., 31, 11-28.

Jenny, S., S. Goes, D. Giardini and H.-G. Kahle (2004). Earthquake recurrence parameters from seismic and geodetic strain rates in the eastern Mediterranean, Geophys. J. Int., 157, 1331-1347; doi:10.1111/j.1365-246X.2004.02261.x.

Kanamori, D.H., and D.L. Anderson (1975). Theoretical basis of some empirical relations in seismology, Bull. Seismol. Soc. Am., 65, 1073-1095.

Karabulut, H., Z. Roumelioti, C. Benetatos, A.K. Mutlu, S. Özalaybey, M. Aktar and A. Kiratzi (2006). A source study

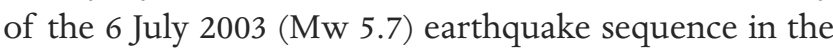
Gulf of Saros (northern Aegean Sea): Seismological evidence for the western continuation of the Ganos fault, Tectonophysics, 412, 195-216.

Kaya, Ş., O. Müftüoglu and O. Tüysüz (2004). Tracing the geometry of an active fault using remote sensing and digital elevation model: Ganos segment, North Anatolian Fault zone, Turkey, Int. J. Remote Sens., 25 (19), 3843 3855.

Kementzetzidou, D. (1996). Étude sismotectonique du systéme Thessalie-iles Sporades (Gréce centrale), PhD Thesis, Observatoire de Grenoble, $151 \mathrm{pp}$.

King, G., A. Tselentis, J. Gomberg, P. Molnar, S. Roecker, H. Sinvhal, C. Soufleris and J. Stock (1983). Microearthquake seismicity and active tectonics of northwestern Greece, Earth Plan. Sci. Lett., 66, 279-288.

Kiratzi, A.A., G.F. Karakaisis, E.F. Papadimitriou and B.C. Papazachos (1985). Seismic source-parameter relations for earthquakes in Greece, PAGEOPH., 123, 27-41.

Kiratzi, A.A. (1991). Rates of crustal deformation in the North Aegean Trough-North Anatolian Fault deduced from seismicity, PAGEOPH, 136 (4), 421-432.

Kiratzi, A., G. Wagner and C. Langston (1991). Source parameters of some large earthquakes in Northern Aegean determined by body waveform modelling, PAGEOPH., 135, 515-527.

Kiratzi, A.A. (1999). Stress tensor inversion in western Greece using earthquake focal mechanisms from the KozaniGrevena 1995 seismic sequence, Annali di Geofisica, 42 (4), 725-734.

Kiratzi, A., and E. Louvari (2003). Focal mechanisms of shal- 
low earthquakes in the Aegean Sea and the surrounding lands determined by waveform modelling: a new database, J. Geodyn., 36, 251-274.

Kiratzi, A., C. Benetatos and Z. Roumelioti (2005). Seismicity and seismotectonic characteristics of ne Aegean Sea and its surrounding lands, Bull. Geol. Soc. Greece, 37, 9-18.

Kiratzi, A. (2010). The 24 May 2009 Mw5.2 earthquake sequence near Lake Doirani (FYROM-Greek borders): Focal mechanisms and slip model using empirical source time functions inversion, Tectonophysics, 490, 115-122, doi:10.1016/j.tecto.2010.04.035.

Kissel, C., and C. Laj (1988). The tertiary geodynamical evolution of the Aegean arc; a paleomagnetic reconstruction, Tectonophysics, 146, 183-201.

Kockel, F., and H. Mollat (1977). Erläterungen zur Geologischen Karte der Chalkidiki und angrenzender Gebiete 1:100.000, Nerd Griechenland. Bundesanstalt für Geowissenschaften und Ruhstoffe, Hannover.

Kondopoulou, D. (2000). Paleomagnetism in Greece: Cenozoic and Mesozoic components and their geodynamic implications, Tectonophysics, 326, 131-151.

Koral, H., H. Öztürk and N. Hanilçi (2009). Tectonically induced coastal uplift mechanism of Gökçeada Island, northern Aegean Sea, Turkey, Quatern. Int., 197, 43-54.

Koukouvelas, I.K. and A. Aydin (2002). Fault structure and related basins of the North Aegean Sea and its surroundings, Tectonics, 21, 1046; doi:10.1029/2001TC901037.

Kulhánek, O., and K. Meyer (1979). Source parameters of the Volvi-Langadhas earthquake of June 20, 1978 deduced from body-wave spectra at stations Uppsala and Kiruna, Bull. Geol. Soc. Am., 69, 1289-1294.

Kurt, H., E. Demirbag and I. Kusçu (2000). Active submarine tectonism and formation of the Gulf of Saros, northeast Aegean Sea, inferred from multi-channel seismic reflection data, Mar. Geol., 165, 13-26.

Laigle, M., A. Hirn, M. Sachpazi and N. Roussos (2000). North Aegean crustal deformation: An active fault imaged to $10 \mathrm{~km}$ depth by reflection seismic data, Geology, 28, 71-74.

Le Pichon, X., and J. Angelier (1979). The Hellenic Arc and trench system: a key to the neotectonic evolution of the eastern Mediterranean area, Tectonophysics, 60, 1-42.

Lybéris, N. (1984). Tectonic evolution of the North Aegean trough, Geol. Soc. London, Sp. Publ., 17, 709-725.

Lybéris, N., and J. Sauvage (1985). Evolution tectonique de la region nord egeenne (Grece) du Pliocene au Pleistocene, Bull. Soc. Geol. France, 8, I, 4, 581-595.

Maley, T.S., and G.L. Johnson (1971). Morphology and structure of the Aegean Sea, Deep-Sea Research, 18, 109-122.

Maravelakis, M. (1936). Study on the earthquakes of Chalkidiki (in Greek), Publ. C. Theodoridou, Thessaloniki, 7, 43 pp.

Mariolakos, I., I. Zagorchev, I. Fountoulis and M. Ivanov
(2004). Neotectonic Transect Moesia Apulia. Field Trip Guide Book, 32nd Int. Geol. Congr., Pre-Congress Field Trip B26, 72 pp.

Martin, L. (1987). Structure et evolution recente de la mer Egee: Apports d'une etude par seismique reflexion, Laboratoire de Geodynamique Sous-marine, VillefrancheSur-Mer, 305 pp.

Mascle, J., and L. Martin (1990). Shallow structure and recent evolution of the Aegean Sea: a synthesis based on continuous reflection profiles, Mar. Geol., 94, 271-299.

McKenzie, D. (1972). Active tectonics of the Mediterranean region, Geophys. J. R. astr. Soc., 30, 109-185.

McNeill, L.C., A. Mille, T.A. Minshull, J.M. Bull, N.H. Kenyon and M. Ivanov (2004). Extension of the North Anatolian Fault into the North Aegean Trough: evidence for transtension, strain partitioning, and analogues for Sea of Marmara basin models, Tectonics, 23, TC2016; doi:10.1029/2002TC001490.

Mercier, J.L., N. Mouyaris, C. Simeakis, T. Roundoyannis and C. Angelidis (1979). Intra-plate deformation: a quantitative study of the faults activated by the 1978 Thessaloniki earthquakes, Nature, 278, 45-48.

Mercier, J.-L. (1981). Extensional-compressional tectonics associated with the Aegean Arc: comparison with the Andean Cordillera of South Peru-North Bolivia, Phil. Trans. R. Soc. London, A300, 337-355.

Mercier, J.-L., E. Carey, N. Mouyaris, K. Simeakis, T. Roundoyannis and C. Anghelidhis (1983). Structural analysis of recent and active faults and regional state of stress in the epicentral area of the 1978 Thessaloniki earthquakes (northern Greece), Tectonics, 2 (6), 577-600.

Mercier, J. L., K. Simeakis, D. Sorel and P. Vergely (1989). Extensional tectonic regimes in the Aegean basins during the Cenozoic, Basin Research, 2, 49-71.

Meyer, B., R. Armjio, D. Massonet, J.-B. De Chabalier, C. Delacourt, J.-C. Ruegg, C. Achache, P. Briole and D. Papanastassiou (1996). The 1995 Grevena (Northern Greece) earthquake: fault model constrained with tectonic observations and SAR interferometry, Geophys. Res. Lett., 23, 2677-2680.

Meyer, B., R. Armijo, D. Massonnet, J.B. de Chabalier, C. Delacourt, J.C. Ruegg, J. Achache and D. Papanastassiou (1998). Comment on "Geodetic investigation of the 13 May Kozani-Grevena (Greece) earthquake" by Clarke et al., Geophys. Res. Lett., 25, 129-130.

Michailidou, A., A. Chatzipetros and S. Pavlides (2005). Quantitative analysis - tectonic geomorfology indicators of the faults at the region of Stratoni-Varvara GomatiM. Panagia in the eastern Chalkidiki, Bull. Geol. Soc. Greece, 38, 14-29.

Mountrakis, D.M., and M.D. Tranos (2004). The Kavala-Xanthi-Komotini fault (KXKF): a complicated active fault zone in Eastern Macedonia-Thrace (northern Greece), 
5th Int. Symp. East. Mediter. Geol., Thessaloniki, Greece, 14-20 April 2004, Proceedings, S1-19.

Mountrakis, D., A. Kilias, S. Pavlides, N. Zouros, N. Spyropoulos, M. Tranos and N. Soulakelis (1993a). Field study of the southern Thessaly highly active fault zone, 2nd Congress of the Hellenic Geophysical Union, 5-7 May 1993, Florina, Greece, Proceedings, 603-614.

Mountrakis, D., G. Syrides, L. Polymenakos and S. Pavlides (1993b). The neotectonic structure of the eastern margin of the Axios-Thermaikos depression at the area of western Halkidiki (central Macedonia), Bull. Geol. Soc. Greece, 28 (1), 379-395.

Mountrakis, D., A. Kilias, S. Pavlides, L. Sotiriadis, A. Psilovikos, Th. Astaras, E. Vavliakis, G. Koufos, G. Dimopoulos, G. Soulios, V. Christaras, M. Skordilis, M. Tranos, N. Spyropoulos, D. Patras, G. Syrides, N. Lambrinos and T. Laggalis (1996a). Neotectonic map of Greece, Langadhas sheet. Earthquake Planning and Protection Organisation and European Centre on Prevention and Forecasting of Earthquakes, scale 1:100,000.

Mountrakis, D., A. Kilias, S. Pavlides, L. Sotiriadis, A. Psilovikos, Th. Astaras, E. Vavliakis, G. Koufos, V. Christaras, M. Skordilis, M. Tranos, N. Spyropoulos, D. Patras, G. Syrides, N. Lambrinos and T. Laggalis (1996b). Neotectonic map of Greece, Thessaloniki sheet (scale 1:100,000), Earthquake Planning and Protection Organisation and European Centre on Prevention and Forecasting of Earthquakes.

Mountrakis, D., S. Pavlides, N. Zouros, Th. Astaras and A. Chatzipetros (1998). Seismic fault geometry and kinematics of the 13 May 1995 western Macedonia (Greece) earthquake, J. Geodyn., 26 (2-4), 175-196.

Mountrakis, D., M. Tranos, C. Papazachos, E. Thomaidou, E. Karagianni and D. Vamvakaris (2006). Neotectonic and seismological data concerning major active faults, and the stress regimes of Northern Greece, Geol. Soc. London, Sp. Publ., 260, 649-670.

Nalbant, S.S., A. Hubert and G.C.P. King (1998). Stress coupling between earthquakes in northwest Turkey and the north Aegean Sea, J. Geophys. Res., 103, 24469-24486.

North, R.G. (1977). Seismic moment, source dimensions, and stress associated with earthquakes in the Mediterranean and Middle East, Geophys. J. R. astr. Soc., 48, 137-161.

Oliveto, A., M. Mucciarelli and R. Caputo (2004). HVSR prospecting in multi-layered environments: An example from the Tyrnavos Basin (Greece), J. Seism., 8, 395-406.

Palyvos, N., K. Pavlopoulos, E. Froussou, H. Kranis, K. Pustovoytov, S.L. Forman and D. Minos-Minopoulos (2010). Paleoseismological investigation of the oblique-normal Ekkara ground rupture zone accompanying the M 6.77.0 earthquake on 30 April 1954 in Thessaly, Greece: Archaeological and geochronological constraints on ground rupture recurrence, J. Geophys. Res., 115, B06301.
Panagiotopoulos, D.G., E.E. Papadimitriou, Ch.A. Papaioannou, E.M. Scordilis and B.C. Papazachos (1993). Source properties of the 21 December 1990 Goumenissa earthquake in northern Greece, 2nd Congress of the Hellenic Geophysical Union, 5-7 May 1993, Florina, Greece, Proceedings, 286-296.

Papadimitriou, E.E and L.R. Sykes (2001). Evolution of the stress field in the northern Aegean Sea (Greece), Geophys. J. Int., 146, 747-759.

Papadimitriou, P., N. Voulgaris, I. Kassaras, G. Kaviris, N. Delibasis and K. Makropoulos (2002). The $\mathrm{Mw}=6.0,7$ September 1999 Athens earthquake, Natural Hazards, 27, 15-33.

Papadopoulos, G.A. (1992). Rupture zones of strong earthquakes in the Thessalia region, central Greece, XXIII Gen. Assembly Europ. Seismol Commission, Prague, September 2, 1992, Proceedings, 2, 337-340.

Papadopoulos, G.A. (2000). Historical earthquakes and tsunamis in the Corinth Rift, central Greece, National Observatory of Athens, Institute of Geodynamics, Publ. n. 12, Athens, $128 \mathrm{pp}$.

Papanastassiou, D. (2001). The Konitsa, Epirus-NW Greece, July $26(\mathrm{Ms}=5.4)$ and August 5, 1996, (Ms = 5.7) earthquakes sequence, Bull. Geol. Soc. Greece, 34 (4), 1555 1562.

Papanikolaou, D., M. Alexandri, P. Nomikou and D. Ballas (2002). Morphotectonic structure of the western part of the North Aegean Basin based on swath bathymetry, Mar. Geol., 190, 465-492.

Papanikolaou, D., M. Alexandri and P. Nomikou (2006). Active faulting in the North Aegean basin, In: Y. Dilek and S. Pavlides (eds.), Postcollisional tectonics and magmatism in the Mediterranean region and Asia, Geol. Soc. Am., Special Paper 409, 189-20.

Papanikolaou, I.D., and D.I. Papanikolaou (2007). Seismic hazard scenarios from the longest geologically constrained active fault of the Aegean, Quaternary International, 171-172, 31-44.

Papastamatiou, D., and N. Mouyiaris (1986). The Sophadhes earthquake occurred on April 30th 1954 - field observations by Yannis Papastamatiou, Geol. and Geoph. Res., Special Issue, 341-362.

Papazachos, B., D. Mountrakis, A. Psilovikos and G. Leventakis (1979). Surface fault traces and fault plane solutions of the May-June 1978 major shocks in the Thessaloniki area, Greece, Tectonophysics, 53, 171-183.

Papazachos, B.C., D.G. Panagiotopoulos, T.M. Tsapanos, D.M. Mountrakis and G.Ch. Dimopoulos (1983). A study of the 1980 summer seismic sequence in the Magnesia region of central Greece, Geophys. J. R. astr. Soc., 75, 155168.

Papazachos, B.C., A.A. Kiratzi, P. Voidomatis and C.A. Papaioannou (1984). A study of the December 1981 -Janu- 
ary 1982 seismic activity in northern Aegean Sea, Boll. Geofis. Teor. Appl., 26 (101-102), 101-113.

Papazachos, B.C. (1990). Seismicity of the Aegean and surrounding area, Tectonophysics, 178, 287-308.

Papazachos, B., A. Kiratzi and E. Papadimitriou (1991). Regional focal mechanisms for earthquakes in the Aegean area, PAGEOPH, 136 (4), 405-420.

Papazachos, C., and A. Kiratzi (1996). A detailed study of the active crustal deformation in the Aegean and surrounding area, Tectonophysics, 253, 129-153.

Papazachos, B., and C. Papazachou (1997). The earthquakes of Greece, 2nd edition, Editions ZITI, Thessaloniki, 304 pp.

Papazachos, B.C., B.G. Karakostas, A.A. Kiratzi, E.E. Papadimitriou and C.B. Papazachos (1998). A model for the 1995 Kozani-Grevena seismic sequence, J. Geodyn., 26, 217-231.

Papazachos, C.B. (1999). Seismological and GPS evidence for the Aegean-Anatolia interaction, Geophys. Res. Lett., 26 (17), 2653-2656.

Papazachos, C.B. (2002). The active crustal deformation field of the Aegean area inferred from seismicity and GPS data, 11 th General Assembly of the Wegener Project, June 1214, Athens, Proceedings.

Papazachos, B., and C. Papazachou (2003). Oi seismoi tis Elladhas, 3rd edition, Editions ZITI, Thessaloniki, 286 pp. (in Greek).

Papazachos, B.C., P.E. Comninakis, E.M. Scordilis, G.F. Karakaisis and C.B. Papazachos (2009). A catalogue of earthquakes in the Mediterranean and surrounding area for the period 1901-Sep. 2009, Publ. Geophys. Laboratory, Aristotle University of Thessaloniki; http: / geophysics. geo.auth.gr (last visited 21/01/2011).

Paradisopoulou, P.M., V.G. Karakostas, E.E. Papadimitriou, M.D. Tranos, C.B. Papazachos and G.F. Karakaisis (2004). Microearthquake study of the broader Thessaloniki area, 5th Int. Symp. East. Mediter. Geol., 14-20 April 2004, Thessaloniki, Greece, Proceedings, 2, 623-626.

Paradisopoulou, P.M., V.G. Karakostas, E.E. Papadimitriou, M.D. Tranos, C.B. Papazachos and G.F. Karakaisis (2006). Microearthquake study of the broader Thessaloniki area (northern Greece), Annals of Geophysics, 49 (4-5), 10811093.

Pavlides, S. (1985). Neotectonic evolution of the Florina-Vegoritis-Ptolemais basin (W. Macedonia, Greece), Ph.D. Thesis, University of Thessaloniki, Greece, 265 pp.

Pavlides, S.B., and A.A. Kilias (1987). Neotectonic and active faults along the Serbomacedonian zone (SE Chalkidiki, northern Greece), Ann. Tectonicae, 1 (2), 97-104.

Pavlides, S.B., and D.M. Mountrakis (1987). Extensional tectonics of northwestern Macedonia, Greece, since the late Miocene, J. Struct. Geol., 9 (4), 385-392.

Pavlides, S., and K. Simeakis (1987/88). Neotectonics and ac- tive tectonics in low seismicity areas of Greece: Vegoritis (NW Macedonia) and Melos isl complex (Cyclades) comparison, Ann. Géol. Pays Helléniques, 33 (2), 161-176.

Pavlides, S., D. Mountrakis, A. Kilias and M. Tranos (1990). The role of strike-slip movements in the extensional area of northern Aegean (Greece). A case of transtensional tectonics, Ann. Tectonicae, 4 (2), 196-211.

Pavlides, S.B., and M.D. Tranos (1991). Structural characteristics of two strong earthquakes in the North Aegean: Ierissos (1932) and Agios Efstratios (1968), J. Struct. Geol., 13, 205-214.

Pavlides, S. (1993). Active faulting in multi-fractured seismogenic areas; examples from Greece, Z. Geomorph. N.F., 94, 57-72.

Pavlides, S., and R. Caputo (1994). The North Aegean region: a tectonic paradox?, Terra Nova, 6, 37-44.

Pavlides, S.B., N.C. Zouros, A.A. Chatzipetros, D.S. Kostopoulos and D.M. Mountrakis (1995). The 13 May 1995 western Macedonia, Greece (Kozani Grevena) earthquake; preliminary results, Terra Nova, 7, 544-549.

Pavlides, S.B. (1998). Dating the neotectonisms in south Almopias (central Macedonia, N. Greece), Bull. Geol. Soc. Greece, 32 (1), 189-197.

Pavlides, S., G.A. Papadopoulos and A. Ganas (2002). The fault that caused the Athens September 1999 Ms 5.9 earthquake: field observations, Nat. Hazards, 27 (1-2), 6184.

Pavlides, S., and R. Caputo (2004). Magnitude versus faults' surface parameters: quantitative relationships from the Aegean, Tectonophysics, 380, 159-188.

Pavlides, S., A. Chatzipetros and Th. Tsapanos (2004a). The Kerkini-Sidirokastro (northern Strymon valley, Greece) active fault and its seismic potential. 4th National Geoph. Conf., 4-5 October 2004, Sofia, Abstracts.

Pavlides, S., V. Kouskouna, A. Ganas, R. Caputo, V. Karastathis and E. Sokos (2004b). The Gonnoi (NE Thessaly Greece) earthquake (June 2003, Ms=5.5) and the neotectonic regime of Lower Olympus, Int. Symp. Eastern Mediterranean Geology, 14-20 April 2004, Thessaloniki, Greece, Proceedings, 2, 627-630.

Pavlides, S., S. Valkaniotis, A. Kurcel, G. Papathanassiou and A. Chatzipetros (2005). Neotectonics of Samothraki Island (NE Aegean, Greece) in relation to the North Anatolian Fault, Bull. Geol. Soc. Greece, 37, 19-28.

Pavlides, S., T. Tsapanos, N. Zouros, S. Sboras, G. Koravos and A. Chatzipetros (2009). Using Active Fault Data for Assessing Seismic Hazard: A Case Study from NE Aegean Sea, Greece, XVIIth Int. Conf. Soil Mech. \& Geotechn. Eng., 2-3 October 2009, Alexandria, Egypt.

Pavlides S., Caputo R., Sboras S., Chatzipetros A., Papathanasiou G. and Valkaniotis S. (2010): The Greek catalogue of active faults and database of seismogenic sources, Bull. Geol. Soc. Greece, 43 (1), 486-494. 
Perissoratis C., Angelopoulos I. and Mitropoulos D. (1991): Surficial Sediment Map of the Aegean Sea Floor: Pagasitikos Sheet, scale 1:200 000, IGME editions, Athens.

Psilovikos, A. (1984). Geomorphological and structural modification of the Serbomacedonian massif during the neotectonic stage, Tectonophysics, 110, 27-45.

Psilovikos, A. and E. Papaphilippou (1990). Pediments, alluvial fans and neotectonic movements of the $\mathrm{Mt}$ Kerkini/Belassitsa, Geologica Rhodopica, 2, 95-103.

Resor, P.G., D.D. Pollard, T.J. Wright and G.C. Beroza (2005). Integrating high-precision aftershock locations and geodetic observations to model coseismic deformation associated with the 1995 Kozani-Grevena earthquake, Greece, J. Geophys. Res., 110, B09402.

Rigo, A., J.-B. de Chabalie, B. Meyer and R. Armijo (2004). The 1995 Kozani-Grevena (northern Greece) earthquake revisited: an improved faulting model from synthetic aperture radar interferometry, Geophys. J. Int., 157, 727736.

Rocca, A.C., G.F. Karakaisis, B.G. Karacostas, A.A. Kiratzi, E.M. Scordilis and B.C. Papazachos (1985). Further evidence on the strike-slip faulting of the northern Aegean Trough based on properties of the August-November 1983 seismic sequence, Boll. Geofis. Teor. Appl., XXVII (106), 101-109.

Rockwell, T., A. Barka, T. Dawson, S. Akyuz and K. Thorup (2001). Paleoseismology of the Gazikoy-Saros segment of the North Anatolia fault, northwestern Turkey: Comparison of the historical and paleoseismic records, implications of regional seismic hazard, and models of earthquake recurrence, J. Seismol., 5, 433-448.

Rondoyanni, Th., Ch. Georgiou, D. Galanakis and M. Kourouzidis (2004). Evidences of active faulting in Thrace region (northeastern Greece), Bull. Geol. Soc. Greece, 36, 1671-1678.

Roumelioti, Z., N. Theodulidis and A. Kiratzi (2007). The 20 June 1978 Thessaloniki (Northern Greece) earthquake revisited: slip distribution and forward modeling of geodetic and seismological observations, 4th Int. Conf. Earthq. Geotech. Eng., June 25-28, Paper No. 1594.

Roussos, N., and T. Lyssimachou (1991). Structure of the central North Aegean Trough: an active strike-slip deformation zone, Basin Research, 3, 39-48.

Saatçilar, R., S. Ergintav, E. Demirbag and S. Inan (1999). Character of active faulting in the North Aegean Sea, Mar. Geol., 160, 339-353.

Sakellariou, D., G. Roussakis, C. Kranis, E. Kamberi, P. Georgiou and N. Skoulikidis (2001). Neotectonic movements, sedimentation and water-level fluctuation of the Lake Vegoritis in Upper Quaternary, Bull. Geol. Soc. Greece, 34, 207-216.

Sboras, S., and R. Caputo (2010). Possible occurrence of lowangle normal faults in central and northern Greece, $29^{\circ}$
Convegno Nazionale di GNGTS, 26-28 October 2009, Prato, Italy, Extended Abstracts, 126-128.

Soufleris, C., and G. Stewart (1981). A source study of the Thessaloniki (northern Greece) 1978 earthquake sequence, Geophys. J. R. astr. Soc., 67, 343-358.

Soufleris, C., J.A. Jackson, G.C.P. King, C.P. Spencer and C.H. Scholz (1982). The 1978 earthquake sequence near Thessaloniki (northern Greece), Geophys. J. R. astr. Soc., 68, 429-458.

Soufleris, Ch., and G. King (1983). A source study of the largest foreshock (on May 23) and the mainshock (on June 20) of the Thessaloniki 1978 earthquake sequence, In: B.C. Papazachos and P.G. Carydis (eds.), The Thessaloniki, Northern Greece, earthquake of June 20, 1978 and its seismic sequence, Technical Chamber of Greece, 201222.

Stanley, D.J., and C. Perissoratis (1977). Aegean Sea ridge barrier-and-basin sedimentation patterns, Mar. Geol., 24, 97107.

Stiros, S.C. (1998). Historical seismicity, paleoseismicity and seismic risk in western Macedonia, Northern Greece, J. Geodyn., 26 (2-4), 271-287.

Stiros, S.C., and A. Drakos (2000). Geodetic constrains on the fault pattern of the 1978 Thessaloniki (Northern Greece) earthquake (Ms=6.4), Geophys. J. Int., 143, 679-688.

Stiros, S., P. Triantafillides and A. Chasapis (2004). Geodetic evidence for active uplift of the Olymbus Mt., Greece, Bull. Geol. Soc. Greece, 36 (4), 1697-1705.

Suhadolc, P., L. Moratto, G. Costa and P. Triantafyllidis (2007). Source modeling of the Kozani and Arnea 1995 events with strong motion estimates for the city of Thessaloniki, J. Earthq. Eng., 11, 560-581.

Taymaz, T., J. Jackson and D. McKenzie (1991). Active tectonics of the north and central Aegean Sea, Geophys. J. Int., 106, 433-490.

Tranos, M.D. (1998). Contribution to the study of the neotectonic deformation in the region of Central Macedonia and North Aegean, $\mathrm{PhD}$ thesis, Aristotle University of Thessaloniki, $349 \mathrm{pp}$.

Tranos, M., E. Papadimitriou and A. Kilias (2003). Thessaloniki-Gerakarou Fault Zone (TGFZ): the western extension of the 1978 Thessaloniki earthquake fault (northern Greece) and seismic hazard assessment, J. Struct. Geol., 25, 2109-2123.

Tranos, M.D. and D.M. Mountrakis (2004). The Serres fault zone (SZF): an active fault zone in eastern Macedonia (northern Greece), 5th Int. Symp. East. Mediter. Geol., Thessaloniki, Greece, 14-20 April 2004, Proceedings, S1-18.

Tselentis, G.-A., E. Sokos, N. Martakis and A. Serpetsidaki (2006). Seismicity and seismotectonics in Epirus, western Greece: results from a microearthquake survey, Bull. Seism. Soc. Am., 96 (5), 1706-1717.

Tüysüz, O., A. Barka and E. Yigitbas (1998). Geology of the 
Saros graben and its implications for the evolution of the North Anatolian fault in the Ganos-Saros region, northwestern Turkey, Tectonophysics, 293, 105-126.

Ustaömer T., Gökaşan E, H. Tur, T. Görüm, F.G. Batuk, D. Kalafat, H. Alp, B. Ecevitoğlu and H. Birkan (2008). Faulting, mass-wasting and deposition in an active dextral shear zone, the Gulf of Saros and the NE Aegean Sea, NW Turkey, Geo-Mar. Lett., 28, 171-193.

Valensise, G., and D. Pantosti (2001). Introduction to the Database, In: G. Valensise and D. Pantosti (eds.), Database of potential sources for earthquakes larger than $\mathrm{M}$ 5.5 in Italy, Annali di Geofisica, Supplement to vol. 44 (4), 797-808.

Valkaniotis, S., A. Zervopoulou, A. Ganas and S. Pavlides (2005). Urban Expansion and Seismic Hazard Increase: Athens and Thessaloniki Examples, In Conference: "Metropolitan Geography: Phenomenon Aspects in Greek Territory", 21-23 October 2005, Thessaloniki, Greece, (in Greek).

Vannucci, G., and P. Gasperini (2003). A database of revised fault plane solutions for Italy and surrounding regions, Computers \& Geosciences, 29, 903-909.

Vannucci, G., and P. Gasperini (2004). The new release of the database of earthquake mechanisms of the Mediterranean area (EMMA Version 2), Annals of Geophysics, Supplement to vol. 47 (1), 307-334.

Voidomatis, P. (1989). Some aspects of a seismotectonic synthesis in the North Aegean Sea and surrounding area, Boll. Geofis. Teor. Appl., 31, 49-61.

Vougioukalakis, G. (2002). Petrological, Geochemical and Volcunological study of the Almopias Pliocene volcanic formations and their correlation with the geothermal manifestations in the area, $\mathrm{PhD}$ Thesis, Aristotle University of Thessaloniki, $303 \mathrm{pp}$.

Wells, D.L., and J.K. Coppersmith (1994). New empirical relationships among magnitude, rupture length, rupture width, rupture area, and surface displacement, Bull. Seism. Soc. Am., 84, 974-1002.

Yaltirak, C., B. Alpar and H. Yüce (1998). Tectonic elements controlling the evolution of the Gulf of Saros (northeastern Aegean Sea, Turkey), Tectonophysics, 300, 227248.

Yaltirak, C., and B. Alpar (2002). Kinematics and evolution of the northern branch of the North Anatolian Fault (Ganos Fault) between the Sea of Marmara and the Gulf of Saros, Mar. Geol., 190, 351-366.

Zervopoulou, A. (2004). Preliminary Report of the active and possible active faults of the broader area of the city of Thessaloniki which will affect the urban area during a probable reactivation, Report Department of Geology, Aristotle University of Thessaloniki, Greece, 35 pp. (in Greek).

Zervopoulou, A., and S. Pavlides (2005). Morphotectonic study of the broader area of Thessaloniki for the cartography of neotectonic faults, Bull. Geol. Soc. Greece, 38, 30-41.

Zervopoulou, A., A. Chatzipetros, L. Tsiokos, G. Syrides and S. Pavlides (2007). Non-seismic surface faulting: the Peraia Fault case study (Thessaloniki, N. Greece), 4th Int Conf. Earthq. Geotech. Eng., June 25-28, 2007, Paper No. 1610.

Zervopoulou, A. (2009). Neotectonic faults of the broader Thessaloniki area in association with foundation soils (in Greek with English abstract), Ph.D. Thesis, Department of Geology, Aristotle University of Thessaloniki, Greece, $300 \mathrm{pp}$.

Zovoili, E., E. Konstantinidi and I.K. Koukouvelas (2004). Tectonic geomorphology of escarpments: the cases of Kompotades and Nea Anchialos faults, Bull. Geol. Soc. Greece, 36, 1716-1725.

\footnotetext{
${ }^{\star}$ Corresponding author:Riccardo Caputo, Università di Ferrara, Dipartimento di Fisica e Scienze della Terra, Ferrara, Italy; email: rcaputo@unife.it.

(C) 2012 by the Istituto Nazionale di Geofisica e Vulcanologia. All rights reserved.
} 